UNIVERSIDADE DE SÃO PAULO

FACULDADE DE FILOSOFIA, LETRAS E CIÊNCIAS HUMANAS PROGRAMA DE PÓS-GRADUAÇÃO EM HUMANIDADES, DIREITOS E OUTRAS LEGITIMIDADES

DANIEL ROBERTO CARNECINE DE OLIVEIRA

Diversidades nas reformas da administração pública brasileira 
DANIEL ROBERTO CARNECINE DE OLIVEIRA

\section{Diversidades nas reformas da administração pública brasileira}

Versão original

Dissertação apresentada à Faculdade de Filosofia, Letras e Ciências Humanas da Universidade de São Paulo para obtenção do título de Mestre em Humanidades, pelo Programa de Pós-graduação em Humanidades, Direitos e Outras Legitimidades.

Orientador:

Prof. Dr. Marcelo Arno Nerling

Área de concentração: Ciências Humanas

São Paulo 
Autorizo a reprodução e divulgação total ou parcial deste trabalho, por qualquer meio convencional ou eletrônico, para fins de estudo e pesquisa, desde que citada a fonte.

Catalogação na Publicação

Serviço de Biblioteca e Documentação

Faculdade de Filosofia, Letras e Ciências Humanas da Universidade de São Paulo

$048 d$

Oliveira, Daniel Roberto Carnecine de

Diversidades nas reformas da administração pública brasileira / Daniel Roberto Carnecine de Oliveira ; orientador Marcelo Arno Nerling. - São Paulo, 2018.

$113 \mathrm{f}$.

Dissertação (Mestrado) - Programa de Pós-Graduação Humanidades, Direitos e Outras Legitimidades da Universidade de São Paulo. Área de concentração: Humanidades, Direitos e Outras Legitimidades.

1. . I. Nerling, Marcelo Arno, orient. II. Título. 
OLIVEIRA, Daniel Roberto Carnecine de. Diversidades nas reformas da administração pública brasileira. Dissertação (Mestrado) apresentada à Faculdade de Filosofia, Letras e Ciências Humanas da Universidade de São Paulo para obtenção do título de Mestre em Humanidades.

Aprovado em:

' 1

Banca Examinadora

Prof. Dr. Instituição

Julgamento Assinatura

Prof. Dr. Instituição

Julgamento Assinatura

Prof. Dr. Instituição

Julgamento Assinatura

Prof. Dr. Instituição Assinatura 
Dedico este trabalho à minha mãe, ao meu pai e minha noiva, pelo amor, apoio, carinho e presença ao longo do período de elaboração desta dissertação. 


\section{AGRADECIMENTOS}

Ao Prof. Dr. Marcelo Arno Nerling, que, nos anos de convivência, muito me ensinou, com sua dedicação e competência, contribuindo para meu crescimento científico, intelectual, profissional e político.

À Profa. Dra. Eucenir Fredini Rocha, pela atenção e apoio durante o processo de qualificação deste trabalho.

À Faculdade de Filosofia, Letras e Ciências Humanas, pela oportunidade de realização do curso. 
O grande jogo da história será de quem se apoderar das regras, de quem tomar o lugar daqueles que as utilizam, de quem se disfarçar para pervertê-las, utilizá-las ao inverso e voltá-las contra aqueles que as tinham imposto; de quem, se introduzindo no aparelho complexo, o fizer funcionar de tal modo que os dominadores encontrar-se-ão dominados por suas próprias regras.

(FOUCAULT, Michel, 2001) 


\section{RESUMO}

OLIVEIRA, Daniel Roberto Carnecine de. Diversidades nas reformas da administração pública brasileira. 2018. 119f. Dissertação (Mestrado) - Faculdade de Filosofia, Letras e Ciências Humanas, Universidade de São Paulo, São Paulo, 2018.

Ao refletir sobre a administração pública, é preciso conhecer o contexto em que está inserida e suas regras e, com base nessa análise, é possível modificar ou criar novas regulamentações, que irão introduzir novas legitimidades. Ao longo dos anos, a evolução da organização do Estado corresponde às necessidades e às complexidades para se adaptar aos cenários de mudanças e transformações. Assim, o Estado foi caracterizado como absoluto, liberal, social-democrático. Bresser-Pereira apresenta o Estado social-liberal. Assim como as formas de governo, que foram definidas, como monarquia, aristocracia e democracia. Também se desenvolveu a teoria do governo misto, o modelo bipartite, a separação de poderes e os governos ditatoriais. $\mathrm{O}$ mesmo ocorreu com os modelos de administrar o Estado, conhecidos como patrimonialista, burocrático e gerencial. Essas concepções determinaram o rumo do papel do Estado e visaram à efetividade de suas ações, tanto para o mercado quanto para os cidadãos. No entanto, atualmente, as reformas adotadas não deram respostas desejadas, tornando-se um desafio transformar a administração pública brasileira federal para melhor servir aos cidadãos. Sendo assim, este trabalho tem como principal objetivo descrever as diversidades das reformas administrativas (DL 200/1967 e EC 19/1998), comparando-as com os tipos "ideais" (patrimonialista, burocrático e gerencial), sob a ótica da desregulamentação e regulamentação. A partir da revisão bibliográfica e de documentos oficiais, o estudo tem o intuito compreender as dificuldades da administração pública federal em suprimir as heranças patrimonialistas, como clientelismo e corrupção, e as disfunções burocráticas, como a centralização e rigidez, utilizando-se da adoção do modelo gerencial para modernizar e racionalizar. Ao se pensar em reformar a administração do Estado brasileiro, é primordial ter como base o papel do Estado, isto é, a sua forma e o seu governo. Para que a reforma da administração pública apresente, como resultado, eficiência em suas ações, é fundamental uma discussão da competência do Estado com relação à sociedade. No entanto, ao continuar pensando de forma peculiar as medidas emergenciais para superação das crises corriqueiras do sistema capitalista, sempre haverá grupos que se favorecerão delas e adotarão as reformas de acordo com seus interesses. Portanto, há a necessidade de alternativas para a administração pública e a adoção de outros conceitos como princípios fundamentais para a administração pública brasileira.

Palavras-chave: Reforma. Estado. Governo. Administração. Legislação 


\begin{abstract}
OLIVEIRA, Daniel Roberto Carnecine de. Diversities in the reforms of the Brazilian public administration. 2018. 119f. Dissertação (Mestrado) - Faculdade de Filosofia, Letras e Ciências Humanas, Universidade de São Paulo, São Paulo, 2018.
\end{abstract}

Reflecting on public administration, it is necessary to know the context in which it is inserted and its rules and, based on this analysis, it is possible to modify or create new regulations, which will introduce new legitimacy. Over the years, the evolution of the organization of the State corresponds to the needs and complexities to adapt to the scenarios of changes and transformations. Thus, the State was characterized as absolute, liberal, social-democratic. Bresser-Pereira presents the social-liberal State. Just like the forms of government that have been defined, such as monarchy, aristocracy and democracy. Also developed was the theory of mixed government, the bipartite model, the separation of powers and dictatorial governments. The same happened with the models of administering the State, known as patrimonialist, bureaucratic and managerial. These conceptions determined the direction of the State's role and aimed at the effectiveness of its actions, both for the market and for the citizens. However, currently, the reforms adopted did not give desired answers, making it a challenge to transform the Brazilian federal public administration to better serve the citizens. Thus, the main objective of this work is to describe the diversity of administrative reforms (DL 200/1967 and EC 19/1998), comparing them with the "ideal" types (patrimonialist, bureaucratic and managerial), from the point of view of deregulation and regulation. Based on the bibliographical review and official documents, the study intends to understand the difficulties of the federal public administration in suppressing patrimonial inheritances, such as clientelism and corruption, and bureaucratic dysfunctions, such as centralization and rigidity, using the adoption of the management model to modernize and rationalize. When thinking about reforming the administration of the Brazilian State, it is essential to have as base the role of the State, that is, its form and its government. For the reform of public administration to present, as a result, efficiency in its actions, it is fundamental a discussion of the competence of the State in relation to society. However, by continuing to think in a special way of emergency measures to overcome the crises of the capitalist system, there will always be groups that will favor them and adopt reforms according to their interests. Therefore, there is a need for alternatives for public administration and the adoption of other concepts as fundamental principles for the Brazilian public administration.

Keywords: Reforms. State. Government. Administration. Legislation. 


\section{LISTA DE QUADROS}

Quadro 1 - Abordagens da administração segundo características, teorias e principais autores

Quadro 2 - Tipos históricos de Estado segundo regime político, administração e democracia..... 54

Quadro 3 - Respostas as crises do modelo burocrático inglês (Whitehall) .................60 60

Quadro 4 - Comparação do modelo patrimonialista.............................................. 74

Quadro 5 - Comparação do modelo burocrático ....................................................... 75

Quadro 6 - Comparação do modelo gerencial....................................................... 78

Quadro 7 - Evolução das práticas na administração pública no Brasil...................... 84

Quadro 8 - Definição de regulação, desregulação, desregulamentação e

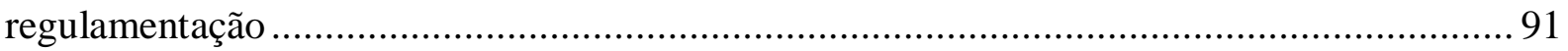




\section{SUMÁRIO}

INTRODUÇÃO

1 AS ABORDAGENS DA ADMINISTRAÇÃO E AS FORMAS DE DOMINAÇÃO 16

$\begin{array}{ll}\text { 1.1 As abordagens da administração geral } & 17\end{array}$

$\begin{array}{ll}\text { 1.1.1 A abordagem clássica } & 18\end{array}$

$\begin{array}{lr}\text { 1.1.2 A abordagem neoclássica } & 20\end{array}$

1.1.3 A abordagem estruturalista $\quad 22$

1.2 As formas de dominação 24

1.2.1. Dominação tradicional 26

$\begin{array}{ll}\text { 1.2.2 Dominação carismática } & 27\end{array}$

1.2.3 Dominação racional-legal $\quad 28$

1.3 Considerações parciais $\quad 35$

2 FORMAS DE ORGANIZAÇÃO DO ESTADO, GOVERNO E ADMINISTRAÇÃO 37

$\begin{array}{ll}\text { 2.1 Modelos de Estado } & 37\end{array}$

$\begin{array}{ll}\text { 2.1.1 Estado absoluto } & 38\end{array}$

$\begin{array}{ll}\text { 2.1.2 O Estado liberal } & 39\end{array}$

$\begin{array}{ll}\text { 2.1.3 O Estado social-democrático } & 40\end{array}$

$\begin{array}{ll}\text { 2.1.4 O Estado social-liberal } & 40\end{array}$

2.2 Formas de governo 4

2.2.1 Teoria do governo misto 45

2.2.2 Modelo bipartite de governo e a separação de poderes 46

$\begin{array}{ll}\text { 2.2.3 Regimes ditatoriais } & 47\end{array}$

$\begin{array}{ll}\text { 2.2.4 Democracia moderna } & 48\end{array}$

2.3 Modelos de administração do Estado

2.3.1 Administração patrimonialista $\quad 55$

2.3.2 Administração burocrática $\quad 56$

2.3.3 Administração gerencial 
$\begin{array}{lr}\text { 2.4 Considerações parciais } & 67\end{array}$

3 A ADMINISTRAÇÃO PÚBLICA FEDERAL

$\begin{array}{ll}\text { 3.1 Modelo patrimonialista brasileiro } & \mathbf{7 3}\end{array}$

3.2 Modelo "ideal” burocrático e o modelo burocrático brasileiro

3.3 O modelo “ideal” gerencial (PSO) e o modelo gerencial brasileiro $\quad 77$

3.4 Interseção dos modelos da administração pública brasileira $\quad 83$

$\begin{array}{ll}\text { 3.5 Considerações parciais } & 87\end{array}$

4 AS DIVERSIDADES DAS REFORMAS 90

4.1 Desregulação patrimonialista da administração pública 91

4.2 Regulação burocrática da administração pública 94

$\begin{array}{ll}\text { 4.2.1 O decreto-lei } \mathrm{N}^{\circ} 200 \text { de } 1967 & 97\end{array}$

$\begin{array}{ll}\text { 4.3 Desregulamentação burocrática } & 101\end{array}$

$\begin{array}{ll}\text { 4.4 Regulamentação gerencial } & 104\end{array}$

$\begin{array}{ll}\text { 4.5 Considerações parciais } & 111\end{array}$

CONSIDERAÇÕES FINAIS

$\begin{array}{ll}\text { REFERÊNCIAS } & 118\end{array}$ 


\section{INTRODUÇÃO}

Ao refletir sobre a administração pública, é preciso conhecer o contexto em que está inserida e suas regras e, com base nessa análise, é possível modificar ou criar novas regulamentações, que irão introduzir novas legitimidades em um novo desenho institucional.

Ao longo dos anos, a evolução da organização do Estado corresponde às necessidades e às complexidades para se adaptar aos cenários de mudanças e transformações. Assim, o Estado foi caracterizado como absoluto, liberal, social-democrático. Bresser-Pereira apresenta o Estado social-liberal. Assim como as formas de governo, que foram definidas, como monarquia, aristocracia e democracia. Também se desenvolveu a teoria do governo misto, o modelo bipartite, a separação de poderes e os governos ditatoriais. O mesmo ocorreu com os modelos de administrar o Estado, conhecidos como patrimonialista, burocrático e gerencial.

Essas concepções determinaram o rumo do papel do Estado e visaram à efetividade de suas ações, tanto para o mercado quanto para os cidadãos, tornando-se um desafio transformar a administração pública brasileira federal para melhor servir aos cidadãos.

A administração pública deveria ser a execução das pressões da sociedade em relação ao Estado, sendo, para tanto, necessário tornar-se mais eficiente. O governo é responsável pelas diretrizes e a administração pública é responsável pela execução dessas diretrizes. Entre a relação governo e administração pública, tem-se a classe que domina as regras. Esta classe é a tecnocracia, ou como Bresser-Pereira definiu de alta carreira do Estado.

No início do Estado Moderno, no século XV, o modelo de administração foi considerado como patrimonialista, que, basicamente, atendia apenas os interesses particulares do grupo político detentor do poder (reis e séquitos). Para tornar a administração do Estado mais racional, Weber (2014) descreveu, em 1920, o modelo burocrático racional-legal. Porém, com o excesso de centralismo, propiciou-se o desenvolvimento de uma administração pública gerencial. $\mathrm{O}$ gerencialismo basicamente focou em desenvolver práticas sobre a importância da participação, transparência e descentralização.

Ao implantar o tipo ideal dos modelos de administração pública no Brasil, percebe-se um enredamento entre eles, ou seja, devido à implantação gradual e parcial, sobretudo do modelo burocrático, ocasionou-se a perpetuação de práticas incompatíveis com a administração pública racional e moderna. Sendo assim, nota-se que, na transição do patrimonialismo para o burocrático, ficaram resquícios de práticas patrimonialistas no modelo burocrático, formando protótipos como, por exemplo, o burocrático-patrimonialista. Observou-se que o 
desenvolvimento dos paradigmas de administração no Brasil relatou situações de resistência para adotar um modelo ideal em sua totalidade, como ocorreu com a administração burocrática, que iniciou em 1930, avançou em 1967 e continuou sendo aperfeiçoada em 1998, com a reforma gerencial. Essa situação produziu modelos de administração pública transitórios e ineficientes.

Deste modo, o objetivo principal desta pesquisa de mestrado é descrever as diversidades das reformas administrativas (DL 200/1967 e EC 19/1998), comparando-as com os tipos “ideais" (patrimonialista, burocrático e gerencial), sob a ótica da desregulamentação e regulamentação. O objetivo secundário constitui-se na descrição das características das formas de organização do Estado, de governo, de administração e os conceitos sobre os modelos "ideais" de administração do Estado. Além disso, também é finalidade deste trabalho descrever as reformas da administração pública federal influencia na atual administração do Estado brasileiro.

A descrição será feita com base na revisão bibliográfica da literatura pertinente e de documentos oficiais concernentes ao objetivo proposto. Em suma, visa compreender as reformas administrativas implantadas no Brasil ao adotar os modelos de administração pública, em que ainda se constata a persistência de práticas patrimonialistas, a resistência em flexibilizar a rígida burocracia e a adoção gerencial incompleta.

Durante a descrição dos processos de adoção das formas de administrar o Estado, notouse a permanência de algumas práticas administrativas que não condizem com uma administração pública racional-legal, que vise uma burocracia para melhor servir as pessoas. Assim, o estudo versará especificamente sobre as reformas da administração pública federal instituída no país, comparando-as com as modelos ideias, reafirmando a implantação lenta e gradual, e principalmente, a perseverança das práticas patrimonialista, da rigidez da burocracia weberiana e do gerencialismo.

O primeiro capítulo descreve as abordagens da administração geral, focando no viés clássico, neoclássico e estruturalista. Esse capítulo, apresenta, também, os tipos de dominação definidos por Weber (2014), detalhando a dominação racional-legal, a dominação tradicional e a dominação carismática. Esses conceitos-chave serão essenciais para direcionar todo o desenvolvimento das formas de Estado, governo e administração.

O segundo capítulo conceitua as formas de organização do Estado (absoluto, liberal, liberal-democrático e social-liberal), as formas de governo (aristocracia, monarquia e democracia), bem como as caraterísticas da democracia (representativa, participativa e deliberativa) e as formas de administrar o Estado (patrimonialista, burocrático e gerencial). 
Esses conceitos de organização do Estado de governo serão cruciais para o entendimento da tensa, dinâmica e contraditória interação entre o regime político e a administração pública.

No terceiro capítulo, estabelece a ligação entre a teoria dos modelos ideais de administrar o Estado e sua adoção na administração pública brasileira, comparando-os e analisando o enredamento entre eles.

No último capítulo, demonstram-se as diversidades das reformas administrativas através da desregulamentação e regulamentação da administração pública federal de acordo com o Decreto-lei 200, de 25 de fevereiro de 1967, e a Emenda Constitucional no 19, de 04 de junho de 1998, relatando como antecedeu a implantação das normatizações e suas respectivas práticas administrativas.

Sendo assim, para o desenvolvimento dos capítulos, utilizou-se como base os respectivos autores; Chiavenato (2008), Bresser-Pereira (2009), Costin (2010), Bobbio (2002), Morin (2000), Faoro (2012), Foucault (2001) e Santos (2011).

Nas considerações finais, buscou-se estabelecer uma discussão sobre a adoção dos modelos de administração do Estado brasileiro, reforçando a importância do tripé formas de Estado, de governo e de administração, com a finalidade de atingir, de maneira satisfatória, um modelo efetivo que melhor sirva às pessoas. Relata-se, também, a necessidade de alternativas para a administração pública e a adoção de outros conceitos como princípios fundamentais para a administração pública brasileira. 


\section{AS ABORDAGENS DA ADMINISTRAÇÃO E AS FORMAS DE DOMINAÇÃO}

A administração é uma ciência recente ${ }^{1}$ e foi responsável, direta ou indiretamente, pelo espetacular aumento da riqueza no último século e também pela melhora na qualidade de vida das pessoas, em especial dos países desenvolvidos (CHIAVENATO, 2008). O aumento da concentração da riqueza gerada pela teoria da administração geral, através da inserção de novos mecanismos, serviu apenas ao grupo que visou à maximização dos lucros. Assim, a racionalização do trabalho, que aprimorou a eficiência na administração privada, trouxe expectativas para melhorar a eficiência dos serviços prestados pela administração pública.

Ao estudar da administração pública, é relevante retomar os conceitos da administração geral, pois estes constituíram a base para o seu desenvolvimento, isto é, os conceitos da teoria estruturalista foram adaptados para a adoção do modelo burocrático e gerencial. Esta pesquisa descreve, através da desregulamentação e regulamentação ${ }^{2}$, as reformas na administração pública no âmbito federal. As abordagens da administração geral formarão o alicerce dos modelos categorizados como ideais, para administrar o Estado.

Recentemente, a reforma da administração pública se tornou essencial, não somente para conter as crises constantes do Estado, mas também para melhorar a prestação de serviços. Para esse fim, foram adotadas práticas pós-burocráticas para melhor servir ao cidadão, fundamentadas pela dominação racional-legal com administração burocrática. Nesse sentido, fez-se necessário desregulamentar as normas vigentes, a fim de regulamentar um novo desenho institucional na administração do Estado.

Ao partir do pressuposto de que o Estado e o governo executam uma ideologia por meio de sua administração (CHIAVENATO, 2008), também não se pode deixar de descrever sobre as formas de dominação, pois a dominação é uma categoria de poder, que segundo Weber (2014) significa toda a probabilidade de impor a própria vontade numa relação social. É justamente por meio da dominação que a administração terá legitimidade para executar suas reformas.

A primeira seção apresentará as abordagens da administração geral de forma resumida, destacando-se as abordagens Clássica, Neoclássica e Estruturalista, já que a administração geral é o resultado cumulativo dessas abordagens e elas constituem os conceitos que interessam para esta pesquisa.

\footnotetext{
${ }^{1}$ O primeiro curso de administração, surgiu na Escola Superior de Administração de Negócios - ESAN/SP em 1941.

${ }^{2}$ Os conceitos de desregulamentação e regulamentação serão explorados no capítulo quatro.
} 
Por fim, na segunda seção, serão abordadas as formas de dominação (patrimonialista, carismática e racional), de modo que será possível ter mais clareza sobre o contexto em que se insere a atual administração pública para que tenha a legitimidade em executar as suas ações.

\subsection{As abordagens da administração geral}

Chiavenato (2008) demonstra, através de uma análise linear, o surgimento de várias abordagens administrativas, que são:

Quadro 1 - Abordagens da administração segundo características, teorias e principais autores

\begin{tabular}{|c|c|c|c|}
\hline Abordagem & Características & Teorias & Principais autores \\
\hline $\begin{array}{l}\text { Clássica } \\
\text { (1900) }\end{array}$ & $\begin{array}{l}\text { Objetivo de aumentar a eficiência } \\
\text { da indústria. }\end{array}$ & $\begin{array}{l}\text { Teoria Clássica; } \\
\text { Administração } \\
\text { Científica }\end{array}$ & $\begin{array}{l}\text { Frederick Winslow } \\
\text { Taylor; Henri Fayol }\end{array}$ \\
\hline $\begin{array}{l}\text { Humanística }{ }^{3} \\
\text { (1932) }\end{array}$ & $\begin{array}{l}\text { Ênfase nas pessoas; aspectos } \\
\text { psicológicos e sociológicos. }\end{array}$ & $\begin{array}{l}\text { Teoria das Relações } \\
\text { Humanas }\end{array}$ & Elton Mayo \\
\hline $\begin{array}{l}\text { Neoclássica } \\
\text { (1954) }\end{array}$ & $\begin{array}{l}\text { Baseou-se em fundamentos como } \\
\text { planejamento, organização, direção } \\
\text { e controle, apoiando-se em } \\
\text { princípios universais, a cultura e o } \\
\text { universo físico e biológico afetam o } \\
\text { meio ambiente do administrador. }\end{array}$ & $\begin{array}{l}\text { Teoria Neoclássica; } \\
\text { Administração por } \\
\text { Objetivos (APO) }\end{array}$ & $\begin{array}{l}\text { Peter F. Drucker, Emest } \\
\text { Dale, Harold Koontz, } \\
\text { Cyril 0'Donnell, Michael } \\
\text { Jucius, William Newman, } \\
\text { Ral ph Davis, George } \\
\text { Terry, Morris Hurley, } \\
\text { Louis Allen }\end{array}$ \\
\hline $\begin{array}{l}\text { Estruturalista } \\
\quad(1947)\end{array}$ & $\begin{array}{l}\text { Enfoque intra-organizacional, } \\
\text { surgiu o enfoque } \\
\text { interorganizacional, isto é, passou a } \\
\text { olhar a organização e as suas } \\
\text { relações com outras organizações } \\
\text { dentro de uma sociedade maior }\end{array}$ & $\begin{array}{l}\text { Teoria da Burocracia; } \\
\text { Teoria Estruturalista }\end{array}$ & Max Weber \\
\hline $\begin{array}{c}\text { Comportamental }^{4} \\
\text { (1957) }\end{array}$ & $\begin{array}{l}\text { Novo olhar da teoria administrativa } \\
\text { baseada no comportamento humano } \\
\text { nas organizações. Também } \\
\text { conhecida como behaviorista. }\end{array}$ & $\begin{array}{l}\text { Teoria } \\
\text { Comportamental da } \\
\text { Administração; } \\
\text { Teoria do } \\
\text { Desenvolvimento } \\
\text { Organizacional } \\
\end{array}$ & $\begin{array}{l}\text { Herbert Alexan- } \\
\text { der Simon. Chester } \\
\text { Bamard, Douglas } \\
\text { McGregor, Rensis Likert, } \\
\text { Chris Argyris }\end{array}$ \\
\hline $\begin{array}{l}\text { Sistêmica } \\
\text { (1951) }\end{array}$ & $\begin{array}{l}\text { Princípios do expansionismo, do } \\
\text { pensamento sintético e da } \\
\text { teleologia. }\end{array}$ & $\begin{array}{l}\text { Teoria Matemática da } \\
\text { Administração; } \\
\text { Teoria de Sistemas }\end{array}$ & $\begin{array}{l}\text { Claude E. Shannon e } \\
\text { Warren Weaver; Von } \\
\text { Neumann H. Raiffa, R. } \\
\text { Schalaifer e R. Howard }\end{array}$ \\
\hline
\end{tabular}

${ }^{3}$ A abordagem Humanística trata de conceitos como, motivação, liderança, comunicação e dinâmica de grupo, isto é, aborda a relação entre o chefe e os subordinados na perspectiva psicológica e sociológica. Assim, as concepções dessa abordagem não serão destacadas nessa pesquisa. Ver Chiavenato (2008).

${ }^{4} \mathrm{O}$ destaca-se na Abordagem Comportamental, a Teoria do Desenvolvimento Organizacional, em suma, ela enfatiza a mudança cultural da organização. O tema não será aprofundado nessa pesquisa, pois não será realizado de estudo de caso para analisar as mudanças culturais na administração pública federal, descrevendo somente sobre as reformas administrativas. 


\begin{tabular}{|c|l|l|l|}
\hline $\begin{array}{c}\text { Contingencial } \\
(1972)\end{array}$ & $\begin{array}{l}\text { Organização como um sistema } \\
\text { composto de subsistemas. }\end{array}$ & $\begin{array}{l}\text { Teoria da } \\
\text { Contingência }\end{array}$ & $\begin{array}{l}\text { Dill, Bums e Stalker, } \\
\text { Chandler, Fouraker e } \\
\text { Stopford, Woodward, } \\
\text { Lawrence e Lorsch }\end{array}$ \\
\hline
\end{tabular}

Fonte: elaboração própria a partir de Chiavenato (2008).

A evolução das abordagens responde às necessidades e à complexidade das organizações ao se adaptarem aos cenários de mudanças e transformações. A presente pesquisa enfatiza as abordagens Clássica, Neoclássica e, principalmente, a Estruturalista, pois são essenciais para as reformas da administração pública federal.

Portanto, ao discorrer sobre a abordagem clássica, serão abordados conceitos que objetivaram melhorar a eficiência na indústria. A abordagem neoclássica apresenta conceitos importantes, como planejamento, organização, direção e controle. Por fim, a abordagem estruturalista, apoia-se na burocracia.

\subsubsection{A abordagem clássica}

A abordagem clássica compreende duas principais teorias: a Escola da Administração Científica de Taylor, com ênfase nas tarefas, e a Teoria Clássica de Fayol, com destaque para as estruturas. Taylor, por meio da Escola de Administração Científica, tinha como objetivo "[...] aumentar a eficiência da indústria por meio da racionalização do trabalho" (CHIAVENATO, 2008), ao passo que Fayol desenvolveu a chamada Teoria Clássica, preocupando-se em “[...] aumentar a eficiência da empresa por meio de sua organização e da aplicação de princípios gerais da Administração em bases científicas" (CHIAVENATO, 2008, p. 25).

A racionalização do trabalho surgiu quando Taylor notou que os trabalhadores aprendiam como executar suas tarefas ao observarem seus companheiros vizinhos. No entanto, havia diferentes métodos para a mesma tarefa e, também, uma variedade de instrumentos e ferramentas para cada operação. A necessidade de reduzir os desperdícios criando mecanismos racionais e padronização na execução das tarefas deu origem à Organização Racional do Trabalho (ORT) (CHIAVENATO, 2008, p. 26).

A substituição dos métodos empíricos e rudimentares por métodos científicos, através da ORT, foi uma resposta à pressão do capitalismo monopolista que surgia na época. Assim, passou a ser base para que as organizações se tornassem eficientes e reduzissem os desperdícios dos métodos rudimentares. Os fundamentos da ORT são: 
1. Análise do trabalho e do estudo dos tempos e movimentos. 2. Estudo da fadiga humana. 3. Divisão do trabalho e especialização do operário. 4. Desenho de cargos e de tarefas. 5. Incentivos salariais e prêmios de produção. 6. Conceito de homo economicus. 7. Condições ambientais de trabalho, como iluminação, conforto etc. 8. Padronização de métodos e de máquinas. 9. Supervisão funcional. (CHIAVENATO, 2008, p. 26).

Assim, o fundamento da ORT deu início a padronização do trabalho, e consequentemente, desenvolvido por Weber (2014) a administração burocrática, trazendo um cenário de mudanças e transformações para a administração pública.

Na Teoria Clássica da Administração, os estudos para aumentar a eficiência e a competência das organizações baseiam-se na substituição do capitalismo liberal pelos monopólios. A produção em massa aumentou o número de assalariados nas indústrias e instituiu a divisão do trabalho para evitar o desperdício e economizar mão-de-obra. Nesse momento, surge a divisão entre os que pensam (gerentes) e os que executam (trabalhadores) e a aplicação de métodos e técnicas da engenharia industrial (CHIAVENATO, 2008, p. 25).

Seguindo a conceptualização da abordagem clássica, numa perspectiva estrutural, a Teoria Clássica desenvolveu o ato de administrar através de cinco elementos, quais sejam:

1. Prever. Visualizar o futuro e traçar o programa de ação. 2. Organizar. Constituir o duplo organismo material e social da empresa. 3. Comandar. Dirigir e orientar o pessoal. 4. Coordenar. Ligar, unir, harmonizar todos os atos e esforços coletivos. 5. Controlar. Verificar que tudo ocorra de acordo com as regras estabelecidas e as ordens dadas. (CHIAVENATO, 2008, p. 32).

Esses cinco elementos são parte do processo administrativo e são considerados como atividades essenciais (padrões), sendo desempenhados pelos gerentes. Esses conceitos começam a traçar o perfil do gerente, que posteriormente serão aprimorados e introduzidos na administração pública.

A abordagem clássica, apesar de se mostrar rígida, inflexível e conservadora frente às mudanças do mundo, é indispensável para a compreensão das bases da moderna Administração. Ainda é utilizada pelos iniciantes em Administração por ser simples e ordenada na execução das tarefas administrativas de rotina, uma vez que examina o trabalho organizacional em categorias compreensíveis e úteis. Ocorrendo o mesmo à administração pública, em diversos casos, ainda há a necessidade de executar conceitos da administração clássica para se pensar em procedimentos modernos na gestão pública.

A Administração Científica deu ênfase às tarefas e a Teoria Clássica enfatizou a Estrutura. Em outras palavras, a Administração Científica deu ênfase à tarefa realizada pelo 
operário, reduzindo os desperdícios e criando um padrão para a execução das tarefas, enquanto a Teoria Clássica concentrou-se na estrutura organizacional, a fim de aumentar a eficiência.

Portanto, a administração pública se utilizou da abordagem clássica para pensar suas tarefas e sua estrutura organizacional. Assim, quando a administração pública adota conceitos do modelo burocrático idealizado por Weber (2014), sua estrutura organizacional se estabeleceu através dos princípios como, prever, organizar, comandar, coordenar e controlar da teoria clássica da administração. Porém, mesmo sendo considerada rígida, inflexível e conservadora, ainda persiste como base conceitual, tornando-se um obstáculo para o alcance da administração moderna e participativa.

\subsubsection{A abordagem neoclássica}

A abordagem neoclássica iniciou-se na década de 1950, quando a teoria administrativa entrou em um período de remodelação pós Segunda Guerra Mundial. O surto de desenvolvimento industrial e econômico, somado ao surgimento da televisão, do motor a jato e do esboço das telecomunicações, fez com que as organizações passassem por grandes mudanças (CHIAVENATO, 2008).

Contudo, os princípios da administração, como a departamentalização, a racionalização do trabalho, a estrutura linear ou funcional, bases da abordagem clássica, não foram totalmente substituídos (CHIAVENATO, 2008). Assim, a abordagem Neoclássica nada mais é do que a abordagem clássica atualizada e redimensionada para os problemas administrativos da época. A abordagem neoclássica é formada pelos seguintes fundamentos:

1. A Administração é um processo operacional composto por funções, como: planejamento, organização, direção e controle. 2. Como a Administração envolve uma variedade de situações organizacionais, ela precisa fundamentarse em princípios básicos que tenham valor preditivo. 3. A Administração é uma arte que, como a Medicina ou a Engenharia, deve se apoiar em princípios universais. 4. Os princípios de administração, a exemplo dos princípios das ciências lógicas e físicas, são verdadeiros. 5. A cultura e o universo físico e biológico afetam o meio ambiente do administrador. Como ciência ou arte, a teoria da Administração não precisa abarcar todo o conhecimento para poder servir de fundamentação científica aos princípios de Administração (CHIAVENATO, 2008, p. 44 - grifo nosso).

Quando estudamos a administração pública, é possível observar os fundamentos da administração neoclássica. O processo operacional composto pelas funções de planejamento, organização, direção e controle está explícito no DL 200/67, em seu artigo $6^{\circ}$ em que estabelece 
que as atividades da administração obedecerão aos princípios como, planejamento, coordenação, descentralização, delegação de competência e controle. E no artigo 37 da CF 88, a administração pública direta e indireta de qualquer dos Poderes da União, dos Estados, do Distrito Federal e dos Municípios obedecerá aos princípios de legalidade, impessoalidade, moralidade, publicidade e eficiência. Sendo esses os princípios universais para a administração pública brasileira.

É importante ressaltar duas principais características da Teoria Neoclássica: a reafirmação dos postulados clássicos e a ênfase nos objetivos e nos resultados. A ênfase nos objetivos e nos resultados elevou as organizações a serem dimensionadas, estruturadas e orientadas para alcançá-los, instituindo-se mecanismos para avaliar o desempenho das organizações, enquanto a reafirmação dos postulados clássicos encontra-se na influência das ciências do comportamento em detrimento dos aspectos econômicos. Assim, a abordagem neoclássica retoma conceitos da abordagem clássica, “[...] redimensionando-o[s] e reestruturando-o[s] de acordo com as contingências da época atual, dando-lhe uma configuração mais ampla e flexível" (CHIAVENATO, 2008, p. 45), sendo, portanto, realinhados para uma nova abordagem, a neoclássica.

Um novo conceito surgido na abordagem neoclássica foi a Administração por Objetivos (APO). Os objetivos “[...] são valores visados ou resultados desejados pela organização" (CHIAVENATO, 2008, p. 46). A APO é identificada como espírito pragmático e democrático da Teoria Neoclássica. Teorizada por Peter F. Drucker, a APO funciona como uma abordagem amigável, democrática e participativa, servindo para a avaliação do desempenho humano, remuneração flexível, sobretudo para a compatibilização entre os objetivos organizacionais e os objetivos individuais das pessoas.

Da concepção da APO, pode-se destacar o esquema a seguir:

1.Gerente e subordinado se reúnem, discutem, negociam e em conjunto formulam os objetivos de desempenho para o subordinado. Objetivos, metas e resultados são negociados entre eles. A formulação de objetivos é consensual e participativa. 2. A partir daí o gerente se compromete a proporcionar apoio, direção e recursos para que o subordinado possa trabalhar eficazmente orientado para o alcance de objetivos. O gerente cobra resultados e garante os meios e recursos (treinamento, habilidades, equipamentos etc.) para que o subordinado possa alcançá-los. 3. O subordinado passa a trabalhar para desempenhar metas e cobra os meios e recursos necessários para alcançar os objetivos. 4. Periodicamente, gerente e subordinado se reúnem para uma avaliação conjunta dos resultados e do alcance dos objetivos. 5. A partir da avaliação conjunta, há uma reciclagem do processo: os objetivos são reavaliados ou redimensionados, bem como os meios e recursos necessários. (CHIAVENATO, 2008, p. 50). 
O esquema da APO apresenta características democráticas e participativas, pois propõe um pacto entre o chefe e o subordinado, visando que a organização atinja seus resultados. Neste momento, passar a ter as tomadas de decisões em conjunto, não somente de cima para baixo de forma autoritária. Assim, são características da APO:

1. Estabelecimento conjunto de objetivos entre o gerente e o seu superior. 2. Estabelecimento de objetivos para cada departamento ou posição. 3. Interligação entre os vários objetivos departamentais. 4. Ênfase na mensuração e no controle de resultados. 5. Contínua avaliação, revisão e reciclagem dos planos. 6. Participação atuante das gerências e dos subordinados. 7. Apoio intensivo do staff. (CHIAVENATO, 2008, p. 50).

Portanto, é possível encontrar na abordagem neoclássica, um novo mecanismo de administração. A APO estabeleceu uma nova dinâmica nas organizações, tornando-as democráticas e participativas. Passou, ainda, a abordar o processo administrativo através do planejamento, da organização, da direção e do controle. Desse modo, a APO é uma ferramenta importante para administração pública, sobretudo quando a esquematização por objetivos supera a relação chefe e subordinado e passa a ter a população nesse processo. Também estabelece uma relação interdepartamental (intersetorial) para a execução de objetivos interligados. Assim, conforme Chiavenato (2008), no mundo em que estamos, em constante mudança e transformação, o processo administrativo não é somente o núcleo da Teoria Neoclássica, mas o fundamento de uma moderna administração.

\subsubsection{A abordagem estruturalista}

A abordagem Estruturalista teve como um dos principais estudiosos Max Weber (2014), teórico da área da sociologia e foi referência para a adoção do modelo burocrático instituído pelo DL 200/1967 no Brasil, que trata da organização da administração federal, estabelecendo diretrizes para a reforma administrativa. A teoria estruturalista surgiu no início do século XX, com Max Weber, tratando das grandes organizações da sua época, seus novos valores e exigências, dando origem ao termo burocracia.

A burocracia surgiu em decorrência da necessidade das organizações de atender às demandas dos trabalhadores que careciam de um tratamento justo e imparcial. A organização burocrática foi uma reação "[...] contra a crueldade, o nepotismo e os julgamentos tendenciosos e parcialistas, típicos das práticas administrativas desumanas e injustas do início da Revolução Industrial" (CHIAVENATO, 2008, p. 54). Assim, a burocracia se consolidou por ter a 
finalidade de organizar detalhadamente e dar uma direção rígida às atividades. Rapidamente, a forma burocrática se alastrou em todos os tipos de organizações humanas. $\mathrm{Na}$ administração pública, passou a ser conhecida como modelo burocrático. Esse modelo é monocrático e está sustentado no direito à propriedade privada, portanto, constituindo uma poderosa classe social, a classe que se apropriará dela para servir-se a si mesma e não para servir às pessoas ${ }^{5}$.

Segundo Chiavenato (2008), Max Weber estudou as organizações sob o ponto de vista estruturalista, isto é, preocupou-se com sua racionalidade, a relação entre os meios e recursos utilizados e os objetivos a serem alcançados. Desse modo, para esse autor, a organização por excelência é a burocracia.

A abordagem estruturalista amplia o enfoque interorganizacional, ou seja, deixa de olhar apenas internamente à organização e passa envolver a organização e suas relações com outras organizações em amplo aspecto. Segundo Chiavenato (2008), a partir desse momento, a abordagem Estruturalista impõe-se sobre a abordagem Clássica e a abordagem das Relações Humanas, mesmo predominando a ênfase na estrutura.

\subsubsection{A teoria estruturalista}

A teoria Estruturalista não está reduzida à Teoria da Burocracia, sendo mais ampla, por representar um "[...] desdobramento da Teoria da Burocracia e uma leve aproximação à Teoria das Relações Humanas" (CHIAVENATO, 2008, p. 65), de forma que o estruturalismo esteja voltado para o todo e para o relacionamento das partes na constituição do todo. A Teoria Estruturalista é representada por grandes figuras da Administração, entre elas,

- A sociedade de organizações;

- As organizações;

- O homem organizacional; e

- A análise das organizações.

A sociedade de organizações é compreendida como um processo de desenvolvimento que está configurado em quatro etapas: da Natureza, do Trabalho, do Capital e da Organização. A etapa da organização ainda está subdividida em quatro períodos de tempo: o universalismo da Idade Média; o liberalismo econômico e social, o socialismo e a atualidade. É possível encontrar, nessas quatro fases, características políticas e filosóficas marcantes. Ao passo que novas formas sociais emergem, as antigas modificam-se e se alteram, adquirindo novos

\footnotetext{
${ }^{5}$ Weber alerta para o surgimento da tecnocracia, através da relação entre governo (diretrizes) e administração (execução) que irão dominar as regras, empoderando-se dela. Bresser, classifica como a alta carreira do Estado.
} 
significados. O aparecimento de organizações complexas em todas as áreas da atividade humana não está isolado de outras mudanças, pois essas organizações são parte integral e fundamental da sociedade moderna (CHIAVENATO, 2008).

Em suma, as organizações formais compreendidas por excelência são as burocracias, por isso, a Teoria Estruturalista tem como expoente aquelas que se iniciaram com a Teoria da Burocracia. O homem organizacional é o surgimento do homem moderno, sendo o reflexo das organizações modernas e industrializadas, e para tanto, ele precisa ter as seguintes características: flexibilidade, tolerância, capacidade de adiar as recompensas, permanente desejo de realização (CHIAVENATO, 2008, p. 69).

Por fim, a análise das organizações da abordagem estruturalista envolve

1. Tanto a organização formal como a organização informal. 2. Tanto as recompensas salariais e materiais como as recompensas sociais e simbólicas. 3. Todos os diferentes níveis hierárquicos de uma organização. 4. Todos os diferentes tipos de organizações. 5. A análise intra-organizacional e a análise interorganizacional. (CHIAVENATO, 2008, p. 69).

Nota-se que a Teoria Estruturalista focou no que diz respeito ao ambiente dentro do conceito de que as organizações são sistemas abertos em constante interação com seu contexto externo, diferenciando-se das teorias antecessoras, que enfatizavam apenas os aspectos internos à organização. Assim, para Chiavenato (2008), a Teoria Estruturalista é uma teoria de transição rumo à Teoria de Sistemas ${ }^{6}$.

Portanto, a Teoria Estruturalista traz conceitos importantes para a administração pública, enfatizando que o ambiente interno das organizações interage com o ambiente externo. $\mathrm{O}$ mesmo ocorre com a administração pública, pois interage com as formas de Estado e governo. Porém, a partir do pressuposto de que o Estado e o governo executam uma ideologia por meio de sua administração (CHIAVENATO, 2008), através das formas de dominação, pois a dominação é uma categoria de poder, que segundo Weber (2014) significa toda a probabilidade de impor a própria vontade numa relação social. É justamente por meio da dominação que a administração terá legitimidade para executar suas reformas.

\subsection{As formas de dominação}

\footnotetext{
${ }^{6}$ Ver Chiavenato (2008).
} 
Para administrar, é necessário ter legitimidade. A dominação significa "[...] a probabilidade de encontrar obediência a uma ordem de determinado conteúdo, entre determinadas pessoas indicáveis" (WEBER, 2014, p. 33). Ou seja, a dominação é pressuposto de que "alguém" manda eficazmente nos "outros". Esse "alguém” são grupos minoritários que detêm o poder usando da dominação para se legitimar. Desse modo, desenvolve-se uma “[...] associação de dominação em que seus membros estejam submetidos a relações de dominação, em virtude da ordem vigente" (WEBER, 2014, p. 33).

A verdadeira relação de dominação está embasada no interesse na obediência, podendo ocorrer por meio do "[...] hábito mais inconsciente até as mais puras racionalmente" (WEBER, 2014, p. 33). A dominação foi classificada de duas formas, sendo uma delas em virtude do interesse e a outra, em virtude da autoridade. A dominação em virtude do interesse é aquela que se manifesta em situação de monopólio, apoiando-se nas influências que pode fazer valer e exercendo uma ação formalmente "livre" e aparentemente voltada para interesses próprios dos dominados.

Já a dominação em virtude da autoridade está na relação de poder de mando e dever de obediência, como, por exemplo, no poder do chefe de família ou da autoridade administrativa, sob o dever de obediência, que é considerado sem atenção a quaisquer motivos e interesses. Para isso, a legitimação da dominação está compelida a operar com o aparato conceitual jurídico, pois é sob o atributo de uma ordem normativa, legalmente existente, que estará regulada uma hierarquia de poder de mando, sendo legalmente constituída e consolidada a obediência sobre os dominados.

A dominação necessita de uma pluralidade de pessoas obedientes para que se possa contar com uma ação dirigida à execução de disposições gerais e ordens concretas. Esse vínculo de obediência ao líder está ligado a motivos de costume, puramente afetivos, interesses materiais, ou por motivos ideais. Dessa maneira, os motivos são materiais e racionais, gerando uma relação instável entre o líder e os seguidores (WEBER, 2014).

A legitimação da dominação, para Weber (2014), não necessariamente é voluntária, ou seja, apenas está sob motivos puramente materiais, afetivos ou racionais, referentes a valores para sua persistência. É necessário despertar e cultivar a crença em sua "legitimidade". Ela deverá ser reconhecida e praticamente tratada como tal. Porém, nem de longe ocorre que toda obediência a uma dominação esteja orientada primordialmente por essa crença e a obediência tanto de um indivíduo quanto de um grupo pode ser disfarçada por uma questão de oportunidade, exercida, na prática, por interesse material próprio ou aceita como inevitável, por fraqueza e desamparo individuais. 
A dominação legítima constitui-se no poder político exercido no período. Sendo assim, no período colonial, predominou a dominação patrimonialista, que sustentou as práticas de interesses pessoais por bastante tempo e caracterizou um Estado sem lei, que iremos chamar, mais adiante, de desregulado ${ }^{7}$, prevalecendo a ausência da distinção entre o público e o privado. Desse modo, a dominação patrimonialista influenciou na forma de administrar o Estado, ou seja, o grupo dominante exerceu a sua legitimidade para administrar o Estado de acordo com os seus interesses pessoais. O mesmo ocorrerá com a dominação carismática e a burocrática, refletindo nas formas de administrar o Estado moderno ${ }^{8}$, atuando em regimes democráticos ou autoritários $^{9}$, impondo a vontade de determinado grupo.

Portanto, segundo Weber (2014), a manutenção da legitimidade de toda dominação pode ser feita através da dominação tradicional, da dominação carismática e da dominação racionallegal.

\subsubsection{Dominação tradicional}

A dominação tradicional tem sua legitimidade estabelecida por meio da crença na santidade de ordens e determina a autoridade em virtude de regras tradicionais. Na dominação predominante no Estado Absoluto, a obediência se faz em virtude da dignidade pessoal do líder dominante que lhe atribui a tradição. A dominação tradicional não respeita estatutos, mas a pessoa indicada pela tradição ou pelo senhor tradicionalmente determinado. Assim, o líder tradicional tem suas ordens legitimadas de dois modos: um em virtude da tradição, que "[...] determina inequivocamente o conteúdo das ordens e da crença no sentido e alcance destas, cujo o abalo por transgressão dos limites tradicionais poderia pôr em perigo a posição tradicional próprio senhor" (WEBER, 2014, p.148), e outro em razão “[...] do livre arbítrio do líder, ao qual a tradição deixa espaço correspondente" (WEBER, 2014, p.148).

A dominação tradicional é uma categoria de poder exercida através de um líder tradicionalmente determinado, seguindo ordens que jamais serão rompidas, pois a mudança na tradição poderá pôr em perigo seu poder.

Existe uma derivação da dominação tradicional, a dominação patrimonial-estamental (ou apenas patrimonialismo), que, em seu tipo ideal, trata "[...] igualmente todos os poderes de mando e direitos senhorais econômicos, e as oportunidades econômicas privadas apropriadas"

\footnotetext{
${ }^{7}$ Esse conceito será melhor detalhado no capítulo três.

${ }^{8}$ A ideia de Estado moderno será melhor discutida no capítulo dois.

${ }^{9}$ Voltaremos à questão dos regimes totalitários no capítulo dois.
} 
(WEBER, 2014, P. 155). Sendo assim, o patrimonialismo é caracterizado

1. pela resistência do tradicionalismo aos estatutos racionalmente constituídos

2. pela ausência de funcionários qualificado

3. pela vontade puramente pessoal, desenvolvimento da corrupção, arrendamento de cargos e aplicação de extorsões

4. pela inerente consequência da natureza da vigência da legitimidade e do interesse de ver satisfeitos os dominados à regulação materialmente orientada da economia

Constantemente se observa, na administração pública, as práticas do patrimonialismo, em especial o arrendamento de cargos, a regulação material orientada da economia, da corrupção, de clientelismos. Nota-se, também, a resistência em mudar a cultura patrimonialista instituída, sendo reproduzida pelo discurso do "sempre foi assim", e constituindo os maiores desafios para atingir o ideal racional-legal com administração burocrática.

\subsubsection{Dominação carismática}

O carisma é uma qualidade pessoal considerada "extracotidiana" (magicamente condicionada) e atribui a uma pessoa "[...] poderes ou qualidades sobrenaturais, sobre-humanos ou, pelo menos, extracotidianos específicos ou então a toma como enviada por Deus" (WEBER, 2014, p. 159). Essa característica envolve uma entrega crente e inteiramente pessoal nascida do entusiasmo ou da miséria e da esperança, ou seja, possui uma força em épocas com forte vinculação à tradição, podendo ser o início da transformação da miséria, modificando a direção de consciência e das ações, com orientação totalmente nova de todas as atitudes diante de todas as formas de vida e diante do mundo.

A dominação carismática representa uma relação social estritamente pessoal, ligada à validade carismática de determinadas qualidades pessoais e à prova destas. Ao assumir uma relação permanente, isto é, uma relação comunitária, a dominação carismática tende a modificar substancialmente seu caráter, tradicionalizar-se ou racionalizar-se, ou a ambas as coisas, em vários aspectos. Essas possíveis mudanças ocorrem por dois motivos: um deles é o interesse ideal e outro é o interesse material, dos adeptos da persistência e reanimação contínua da comunidade, assim, o carisma é

[...] uma qualidade pessoal considerada extracotidiana (na origem, magicamente condicionada, no caso tanto dos profetas quanto dos sábios 
curandeiros ou jurídicos, chefes de caçadores e heróis de guerra) e em virtude da qual se atribuem a uma pessoa poderes ou qualidades sobrenaturais, sobre-humanos ou, pelo menos, extracotidianos específicos ou então a toma como enviada por Deus, como exemplar e, portanto, como "líder". (Weber, 2014, p.159).

Portanto, a dominação carismática poderá ser um momento transitório de dominação, que depende da relação comunitária, modificando-se para uma dominação tradicional ou para uma dominação racional. Geralmente, em períodos de crise do Estado, a dominação carismática aparece, apontando a necessidade das relações comunitárias de contar com a figura do messias (líder carismático) para sanar os problemas.

\subsubsection{Dominação racional-legal}

A dominação burocrática é fundamental para a relação de dominação entre o governo e a sociedade civil por meio de estatutos, isto é, da criação de leis e normas que mantenham uma determinada ordem social baseada no fato de que todo direito, mediante a um pacto ou imposição, pode ser estatuído de modo racional com a pretensão de ser respeitado, conforme atesta Weber (2014, p. 142):

1. que todo direito, mediante a pacto ou imposição, pode ser estatuído de modo racional - racional referente a fins ou racional referente a valores (ou ambas as coisas) - com a pretensão de ser respeitado pelo menos pelos membros da associação, mas também, em regra por pessoa que, dentro do âmbito de poder desta, realizem ações sociais ou entrem em determinadas relações sociais, declaradas relevantes pela ordem da associação; 2. que todo direito é, segundo a sua essência, um cosmo de regras abstratas, normalmente estatuídas com determinadas intenções; que a judicatura é a aplicação dessas regras ao caso particular e que a administração é o cuidado racional de interesses previstos pelas ordens da associação, dentro dos limites das ordens jurídicas e segundo princípios indicáveis de forma geral, os quais encontram aprovação ou pelo menos, não são desaprovados nas ordens da associação; 3. que, portanto, o senhor legal típico, o "superior", enquanto ordena e, com isso, manda, obedece por sua parte à ordem impessoal pela qual orienta suas disposições.

A ação social, é a ação orientada a outro indivíduo, quando a sua formação de dominação se baseia numa relação associativa racional, encontra seu tipo específico na "burocracia". Assim, a dominação necessita de uma pluralidade de pessoas, obedientes, para que se possa contar em uma ação dirigida à execução de disposições gerais e ordens concretas. (WEBER, 2014).

Segundo Weber (2014, p. 143), para atingir a racionalidade plena na aplicação das regras, 
é necessária a qualificação profissional, ou seja, que somente os funcionários qualificados que dominem uma especialização possam ser aceitos para participar do quadro administrativo (tecnocracia), e constituam tipicamente o quadro administrativo de associações racionais, sejam estas políticas, hierocráticas, econômicas ou outras.

Para Weber (2014), ao atingir a racionalidade plena, não haverá mais nenhuma apropriação do cargo pelos detentores, pois estará constituído um "direito" ao "cargo". Os funcionários públicos não usarão ou não deverão usar para o fim a sua apropriação pelo cargo, mas, sim, para garantir seu trabalho de caráter puramente objetivo ("independente"), apenas vinculado a determinadas normas no respectivo cargo, impossibilitando as condições em que os funcionários públicos se sirvam das associações.

Um dos desafios da atual administração pública é a distinção na relação do funcionário com o cargo, do qual, na maioria das vezes, o funcionário se utiliza para fins de interesse próprio, retendo informações para obter privilégios na conquista de uma posição de chefia ou um melhor salário.

A necessidade da qualificação profissional cresceu continuamente na burocracia devido ao aumento de sua complexidade. De acordo com Weber (2014), houve a pressão para que os funcionários dos partidos e sindicatos se desenvolvessem em conhecimentos específicos (empiricamente adquiridos), diferentemente dos cargos eletivos, que são os únicos com "funcionários" dos quais não se exige nenhuma qualificação profissional, o que demonstra que eles são funcionários apenas no sentido formal da palavra, e não no sentido material.

$\mathrm{Na}$ dominação racional legal com administração burocrática, encontra-se uma administração pública que exigirá uma qualificação técnica para o exercício do cargo, seja para os cargos efetivos (carreira), para os cargos de livre nomeação e exoneração ou para os cargos eletivos. Além disso, desenvolverá um grupo que, sob o domínio do conhecimento específico, irá deter controle e influência do poder e das tomadas de decisões. Tornará, ainda, a administração pública mais profissional e complexa, evitando decisões por paixões ou entusiasmo, que privilegiam os interesses individuais ou de um pequeno grupo, passando a decidir de forma igualitária e racional. Assim, a administração burocrática tem a dominação em virtude do conhecimento, sendo este seu caráter fundamental especificamente racional, tomando uma posição formidável devido ao seu conhecimento profissional, fortalecendo ainda mais, pelo saber prático de serviço, aquele que dela se serve, desenvolvendo-se o conceito burocrático do "segredo oficial".

A administração burocrática significa: dominação em virtude do 
conhecimento; este é seu caráter fundamental especificamente racional. Além da posição de formidável poder devido ao conhecimento profissional, a burocracia (ou o senhor que dela se serve) tem a tendência de fortalecê-la ainda mais pelo saber prático de serviço: o conhecimento de fatos adquiridos na execução de tarefas ou obtido via "documentação". O conceito (não só, mas especificamente) burocrático do "segredo oficial" - comparável em sua relação ao conhecimento profissional, aos segredos das empresas comerciais no que concerne aos técnicos - provém desta pretensão de poder. (WEBER, 2014, p.147).

É importante destacar que são extremamente raros os tipos puros de dominação supracitados, pois o fundamento de toda dominação consiste no "prestígio" do dominador ou dos dominadores, assim, a dominação legal nunca é puramente legal, visto que a crença na legalidade é um "hábito", condicionada pela tradição e, em caso de rompimento, é capaz de anular. É, também, carismática, no sentido negativo de que o insucesso contínuo e notório é a ruína de todo governo, ao quebrar seu prestígio e permitir a maturação de revoluções carismáticas (WEBER, 2014). Por conseguinte, é possível notar que, na administração pública, as formas de dominação influenciam na definição da forma de administrar o Estado, conduzindo para uma relação de sua época com a manutenção de poder.

\subsubsection{A dominação do Estado moderno}

Os tipos de dominação regem os princípios e as formas de administrar o Estado. Assim, sempre haverá a dominação de um grupo hegemônico sobre o outro, adotando práticas na forma de administrar o Estado para atender exclusivamente seus interesses. Para Weber (2014), o Estado moderno detém o monopólio da coerção física legítima, isto é, tem a legitimidade para empregar ou delegar seu uso para a obediência ${ }^{10}$ da população. A dominação legítima é necessária para que o Estado faça prevalecer a ordem estabelecida.

No Estado moderno, o domínio efetivo, está no cotidiano da administração, encontrandose nas mãos do funcionalismo, tanto do civil quanto do militar. O progresso em direção ao funcionalismo burocrático é baseado em “[...] contrato, salário, pensão, carreira, treinamento especializado e divisão de trabalho, competências fixas, documentação e ordem hierárquica" (WEBER, 2014, p. 530), sendo critério igualmente unívoco da modernização do Estado. O "progresso" em direção ao Estado burocrático, sob a base de um direito racionalmente estatuído

10 “Obediência" significa, para Weber, que a ação de quem obedece ocorre substancialmente como se este tivesse feito do conteúdo da ordem e em nome dela a máxima de sua conduta, e isso unicamente em virtude da relação formal de obediência, sem tomar em consideração a opinião própria sobre o valor e desvalor da ordem como tal. 
e de regulamentos racionalmente concebidos, encontra-se em conexão "muito íntima com o desenvolvimento capitalista moderno" (WEBER, 2014, p. 530). Dessa forma, a dominação burocrática é essencial para qualificar seus quadros a fim de que detenham o conhecimento legal da organização do Estado e para manter os interesses do grupo dominante, que impõe a sua execução, trazendo para a racionalidade a importância da preservação desses interesses.

Sendo assim, a base do Estado burocrático, segundo Weber (2014), é mantida pelos funcionários públicos, dividindo-os em duas categorias, os funcionários políticos e os funcionários especializados. Os funcionários políticos podem ser transferidos ou demitidos, têm como competência manter a "ordem" no país, ou seja, as condições de dominação existente e cumprem um papel importante no Estado moderno, a saber, a manutenção da forma de governo, nesse caso, da democracia, ajudando e direcionando seu líder, pela confiança que exerce, nas tomadas de decisões conforme suas concepções ideológicas, material ou racional.

De acordo com Weber (2014), diferentemente dos funcionários políticos, os funcionários especializados não devem fazer política ${ }^{11}$, mas administrar, sobretudo de modo imparcial. Dessa forma, os funcionários especializados exercem seu cargo "sem ódio e favor", Isto é, não deve se utilizar das informações oriundas do cargo para obter vantagens particulares, devendo "obedecer" ao que determina a lei.

Assim, Weber (2014) separa de forma rígida as competências entre os funcionários políticos e os especializados. Porém, a subordinação não deve ser extrema, ou seja, ao funcionário, cabe repetir que recebe uma ordem, mas, em caso de ser seu entendimento errôneo, pode e deve fazer objeções, independentemente se a instância superior é uma "autoridade", uma "corporação" ou uma "assembleia" com mandato imperativo. Um líder político que atuar sem seguir a legalidade merecerá o desprezo. Para que não se infrinja a legalidade vigente é que surge a desregulamentação e regulamentação, isto é, que desregula a norma vigente (legalidade) e regula uma nova norma (que passa a ser legal) com a finalidade de atender os anseios da sociedade em um determinado momento.

Para Weber (2014, p. 576), a impotência e a corrupção dos parlamentares conduziram, em alguns Estados, à ampliação da legislação popular direta, ou seja, deixou-se de tratar as massas meramente como objeto passivo da administração, passando a permitir que interferissem ativamente por meio de sua opinião. Nesse contexto, surgem as "massas não-

${ }^{11}$ Para Weber (2014), o ideal racional dos funcionários é que somente executassem de forma racional as diretrizes do grupo eleito, sem interferir politicamente nas decisões. Porém, observamos cada vez mais funcionários especializados fazendo política, tanto na orientação nas tomadas de decisões, quanto tomando decisões próprias. 
organizadas", a democracia da rua, caracterizada pela ausência de partidos racionalmente organizados. A ausência de atuação honesta e racional levou a população, de forma "obrigatória", a se envolver ativamente, formando opinião e, consequentemente, a organizar partidos de modo irracional. De fato, ao analisar o excesso de partidos no Brasil, percebemos como atuam e quais são suas necessidades: em sua maioria, as opiniões visam somente a atender as necessidades individuais e materiais.

Atualmente, com a globalização, com o surgimento de agrupamentos como entidades supraestatais ou com a imposição de regras por meios de organismos internacionais (COSTIN, 2010), criou-se um grupo internacional dominante que interferiu, principalmente nos país subdesenvolvidos, para que adotassem formas de administrar os Estados de acordo com suas determinações. Entre esses grupos internacionais, podemos destacar o Banco Mundial e o FMI.

\subsubsection{A dominação da administração pública}

É necessário discutir, a partir das concepções de Weber (2014), a dominação da administração pública, já que foram esses conceitos que determinaram o rumo da administração pública brasileira. No Brasil, especificamente no período Vargas, em 1930, através de um regime político autoritário, ocorreu a chamada reforma burocrática, que teve como um dos conceitos principais a dominação racional-legal com administração burocrática.

Segundo Weber (2014) o funcionamento específico do funcionalismo moderno está baseado em três princípios, o princípio das competências oficiais fixas, o princípio da hierarquia de cargos e o princípio da sequência de instâncias. O princípio das competências oficiais fixas é definido mediante a leis ou regulamentos administrativos e rege através de uma distribuição fixa das atividades regularmente necessárias para executar os fins do complexo burocraticamente dominado. Essa fixação distributiva dos poderes de mando para o cumprimento regular e contínuo dos deveres definirá a contratação de pessoas de qualificação normatizada. Quanto ao princípio da hierarquia de cargos, trata-se de um “[...] sistema fixamente regulamentado de mando e subordinação das autoridades, com fiscalização das inferiores pelas superiores" (WEBER, 2014, p. 199), isto é, a partir da hierarquia, fiscalizamse os subalternos de acordo com sua dominação. Por fim, o princípio da sequência de instâncias hierárquica é encontrado tanto em formações estatais e eclesiásticas, quanto em todas as demais formações burocráticas, como, por exemplo, grandes organizações de partido e grandes empresas privadas.

A dominação racional-legal da administração pública, encontram-se os princípios que são 
a definição de competências fixadas em lei, a definição dos níveis hierárquicos dos cargos e a sequência de instâncias hierárquicas, sendo essas a sua base de sustentação e vigente até hoje na administração pública federal.

$\mathrm{Na}$ estrutura da dominação racional-legal, encontram-se dois tipos de funcionário, o burocrático e o eleito. O funcionário burocrático é nomeado por uma instância superior. Já os funcionários eleitos são escolhidos pelos dominados e deixam de ser figuras puramente burocráticas. Contudo, a aparente formalidade de uma eleição não impede que, por trás, haja uma nomeação, tendo em vista que essas nomeações são efetuadas pelos chefes de partidos ao definirem quem será seu representante nas eleições.

A nomeação também abrange os cargos de competências fixadas que são de responsabilidade da autoridade. Uma prática comum, atualmente, são as nomeações de funcionários não qualificados, prática que, para Weber (2014), debilitará a dependência hierárquica e comprometerá o funcionamento preciso do mecanismo burocrático, colocando em risco sua dominação. Todavia, quando se tem um quadro capacitado de funcionários, estes determinam o avanço da organização burocrática, assim, a “[...] precisão, a rapidez, a univocidade, o conhecimento da documentação, a continuidade, a discrição, a uniformidade, a subordinação rigorosa, a diminuição de atritos e os custos materiais e pessoais" (WEBER, 2014, p. 212) atingirão o ponto ótimo numa administração rigorosamente burocrática e legitimarão de forma eficaz a dominação do grupo que estará no poder.

Outro ponto a se destacar é a importância da continuidade do trabalho pelo quadro administrativo quando há mudanças de governo. A continuidade pode se caracterizar não somente por condições econômicas privadas, mas também de natureza objetiva (ideológica), sob condições em que a paralisação da administração significaria a ruína do abastecimento da população inteira, inclusive dos próprios funcionários, logo, o "sentimento do dever" (objetivo) dos funcionários, e mesmo os poderes até então legítimos e seus partidários, reconheceram essa necessidade objetiva (WEBER, 2014).

Desse modo, segundo Weber (2014), para manter o abastecimento à população (os serviços públicos), a racionalização burocrática assegura a continuidade das ações da administração pública e a importância da alternância de poder, evitando, em caso de troca da associação política divergente, que ocorra a súbita paralisação dos serviços.

É importante ressaltar que Weber (2014) descreve a dominação burocrática no momento de consolidação do capitalismo como o único meio de produção e crescimento do liberalismo, sendo assim, toda a estrutura burocrática de administração do Estado está sob a dominação racional-legal de uma elite com propósitos de conduzir a administração pública para dar 
resposta efetiva a seus interesses capitalistas.

Em linhas gerais, a estrutura burocrática é de caráter racional e será fundamentada em regra, finalidade, meios e impessoalidade. A racionalidade visou combater as práticas patrimoniais em que o Estado era sem leis, desregulado, regido apenas por interesses pessoais e em que não havia diferenciação entre o público e o privado. Sendo assim, a estrutura burocrática ajudou a aniquilar as distorções, suprimindo as estruturas de dominação de base patrimonialista.

Há, ainda, outra forma de dominação que se manifesta no Estado moderno através de suas instituições, a saber, a dominação institucional. O meio mais utilizado pelo Estado moderno é o da coação física. Apoiado como legítimo (ou melhor, considerado legítimo), esse meio parte de uma relação de dominação de homens sobre homens. Assim, para Weber (2014), a dominação institucional pretendeu com êxito monopolizar a coação física legítima como meio da dominação.

As pessoas se submetem à autoridade invocada pelas que dominam no momento dado. Todavia, os fundamentos da legitimidade de uma dominação são baseados em três princípios, sendo eles,

1) a autoridade do "eterno ontem", do costume sagrado por validade imemorável e pela disposição habitual de respeitá-lo: dominação "tradicional", tal como a exerciam o patriarca e o príncipe patrimonial de antigamente; 2) a autoridade do dom de graça pessoal, extracotidiano (carisma): a entrega pessoal e a confiança pessoal em revelações, heroísmo ou outras qualidades de líder de um indivíduo: dominação, "carismática", tal como a exercem o profeta ou - na área política - o príncipe guerreiro eleito ou o soberano plebiscitário, o grande demagogo e o chefe de um partido político; 3) a dominação, em virtude de "legalidade", da crença na validade de estatutos legais e da "competência" objetiva fundamentada em regras racionalmente criadas, isto é, em virtude da disposição de obediência ao cumprimento de deveres fixados nos estatutos: uma dominação como a exercem o moderno "servidor público" e todos aqueles portadores de poder que com ele se parecem neste aspecto. (WEBER, 2014, p. 526).

De fato, são perceptíveis os fundamentos da legitimidade de uma dominação até hoje, enredando-se entre si ou, até mesmo, atuando concomitantemente. Percebe-se, em certos momentos, na administração pública, analisando-se cada uma das manifestações, (1) a finalidade tradicional se caracterizou de forma mais intensa no período colonial, por meio do costume sagrado. (2) A carismática teve e tem sua presença em regimes presidencialistas e, por fim, a (3) dominação legal frequentemente exercida pelos servidores públicos, que seguem a lei rigorosamente fixada, mesmo não sendo esta mais eficaz ao seu tempo, obedecendo-a 
rigidamente.

Finalmente, para Foucault (2001), a dominação da administração pública fixa-se precisamente em cada momento da história em um ritual. Impondo obrigações e direitos, ela constitui cuidadosos procedimentos, instituindo a obrigação legal da obediência. Dessa forma, o direito é o instrumento dessa dominação, não somente através das leis, mas no conjunto de aparelhos, instituições e regulamentos que o aplicam, colocando em prática as relações de dominação. Portanto, a regra permite que uma outra dominação possa dobrar aqueles que dominam e ela pode ser burlada ao sabor da vontade de uns ou de outros, de modo que "[...] o grande jogo da história será de quem se apoderar das regras, de quem tomar o lugar daqueles que as utilizam, de quem se disfarçar para pervertê-las, utilizá-las ao inverso e voltá-las contra aqueles que as tinham imposto" (FOUCAULT, 2001, p. 25).

\subsection{Considerações parciais}

Objetivou-se demonstrar, neste capítulo, as abordagens da administração geral, pois a análise desta pesquisa será estrutural e a descrição do desenvolvimento das leis que instituíram as reformas administrativas na administração pública federal, que foram baseadas em conceitos clássicos da administração geral, a teoria clássica (tarefas e estruturas), a neoclássica (gerente) e a estruturalista (burocracia).

Assim, a Administração Científica fundamentou, através de métodos científicos, a realização dos trabalhos rotineiros, contribuindo para a gerência; a Teoria Clássica visou às funções de direção, colaborando para a direção; e a Teoria Estruturalista definiu as características da burocracia, cooperando para a organização como um todo (CHIAVENATO, 2008). Porém, há um fator determinante para que as reformas administrativas sejam reguladas e alcancem a eficiência, qual seja, será através da dominação.

A dominação é uma categoria de poder, vigente em uma determinada época, sendo a relação de poder de um determinado grupo. Este primeiro capítulo foi a base de conceitos para compreender como se chegou à adoção de práticas da administração geral para a administração pública.

Weber (2014) definiu que, na administração pública, sempre haverá alguma forma de dominação, pois é essencial que certos poderes de mando estejam nas mãos de alguém, sendo o dominador considerado o "servidor" dos dominados e se sentindo também como tal. A manutenção do exercício da dominação também ocorre da continuidade para que a administração pública se desenvolva qualitativamente e quantitativamente nas tarefas 
administrativas. Assim, na manutenção de parte dos servidores públicos, que detém a superioridade técnica sobre os assuntos públicos, sempre haverá a probabilidade de que se constitua uma formação social especial e perene para os fins administrativos.

Tem-se que a dominação racional legal com administração burocrática é especificamente vinculada as regras discursivamente analisáveis. A carismática é especificamente irracional, no sentido de não conhecer regras, e a tradicional está vinculada aos precedentes do passado, e, neste sentido, também é orientada por regras (WEBER, 2014). É por intermédio dessas relações de dominação que serão formados os governos sob a organização de partidos políticos que regerão a administração pública, determinando toda a desregulamentação e regulamentação do Estado. Portanto, a evolução das abordagens da administração geral e das formas de dominação respondem às necessidades e às complexidades das organizações ao se adaptarem aos cenários de mudanças e transformações. 


\section{FORMAS DE ORGANIZAÇÃO DO ESTADO, GOVERNO E ADMINISTRAÇÃO}

Segundo Dallari (1998), a palavra "Estado" vem do latim status, que significa "estar firme", isto é, está em situação permanente de convivência e ligada à sociedade política. $\mathrm{O}$ termo surgiu em $O$ Príncipe, de Maquiavel, indicando o Estado como sociedade política. Assim, há duas origens para a formação do Estado: a primeira é a formação natural ou espontânea, isto é, de um ato puramente voluntário; a segunda é aquela que sustenta a formação contratual do Estado, cuja criação decorre da vontade de alguns ou de todos. Porém, quando as sociedades atingem um grau de desenvolvimento complexo, têm a absoluta necessidade do Estado. .

De acordo com Weber (2014), a obediência ao direito próprio, sob a regra instituída, estabelece quem e em que medida se deve obedecer (dominação racional-legal). Este é o fundamento para o Estado de direito e, consequentemente, qualquer direito pode ser criado e modificado, ou seja, pode ser regulado (criado) e desregulamentado (modificado ou suprimido). Com base nesses conceitos, nos últimos séculos, ocorreram constantes alterações das formas de organização do Estado, governo e administração.

O presente capítulo irá abordar as formas de organização do Estado, governo e administração. Na primeira seção, serão apresentadas as características do Estado moderno (absoluto, liberal, social-democrático, social-liberal). Na segunda seção, serão expostas as formas de governo (monarquia, aristocracia, democracia, governo misto, modelo bipartite, separação de poderes e os regimes ditatoriais). Por fim, na última seção, será feita a descrição dos modelos de administração do Estado (patrimonialista, burocrático e gerencial). Ao apresentar esses três aspectos, objetiva-se demonstrar que a reforma da administração pública é dependente do tripé Estado-governo-administração para ser consolidada.

Portanto, ao demonstrar o caminho percorrido pelas formas de organização do Estado, de governo e da administração, através da dominação racional-legal, que resultou em uma estrutura hierarquizada, centralizada e no saber técnico especializado. Para assim, responder às necessidades e à complexidade da organização do Estado, governo e administração, para se adaptarem aos cenários de mudanças e transformações.

\subsection{Tipos de Estado}

O estudo da história da organização do Estado, governo e administração, segue o estudo das leis, pois são elas que regulam as relações entre governantes e governados, através do conjunto de normas. Assim, torna-se possível descrever a "passagem do Estado feudal à 
monarquia absoluta, ou a gradual formação do aparato administrativo, através do qual pode-se reconstruir o processo de formação do Estado moderno e contemporâneo" (BOBBIO, 2007, p.54)

Os modelos de Estado refletem a relação entre os governantes e os governados e são estabelecidos por meio do contrato social vigente. Esse contrato variou ao longo dos anos, de acordo com o contexto econômico e social dos países. Ao passo que a economia evolui, a forma como os bens são socialmente distribuídos foi repactuada, e a cada novo pacto social, as elites dominantes exigiam revisão das regras do jogo econômico.

Desse modo, considerado o percursor do Estado Moderno, o período absolutista estabeleceu-se sob um pacto social em que a obediência ao estado decorria do entendimento de que apenas ele poderia garantir suprimento e segurança. Com o advento das novas formas de mercado, houve a compreensão de que as burguesias garantem um melhor nível econômico, sem a intervenção direta do Estado, resultando na adoção do modelo de Estado Liberal, protetor da livre-iniciativa privada.

Ao mesmo tempo em que a burguesia ascendia economicamente, à custa da exploração da mão de obra dos pobres, houve reivindicação dos mesmos pela distribuição da renda, que só poderia ser organizada pelo Estado, visto que este deve zelar pela justiça social. Esse movimento originou o Estado social-democrático, que tem por objetivo o estabelecimento do bem-estar social keynesiano.

Por fim, nos dias de hoje, as classes dominantes percebem que um verdadeiro Estado de Bem-Estar Social e uma democracia em pleno funcionamento colocam em risco sua dominação econômica. Por essa razão, pediram o fim do investimento estatal em Bem-Estar Social, restringindo a efetivação da democracia, para garantir a manutenção do status quo.

\subsubsection{Estado absoluto}

O Estado absoluto é a primeira manifestação histórica do Estado moderno. Surgiu no século XVI, após o fim da Idade Média, com a finalidade de superar o estado de natureza do feudalismo, através de um contrato social fruto do acordo político entre a burguesia emergente e o monarca. Esse acordo favoreceu o rei na obtenção de recursos para reforçar seu poderio militar e impor seu domínio sobre uma aristocracia feudal (BRESSER-PEREIRA, 1998). O contrato social $^{12}$ foi uma nova maneira de legitimar o poder absoluto do rei, afirmando que a

\footnotetext{
${ }^{12} \mathrm{O}$ ponto inicial do contrato social é quando a condição humana passa do chamando "estado de natureza" para uma um acordo entre os membros da sociedade, pelo qual reconhecem a autoridade, igualmente sobre todos,
} 
autoridade do monarca não se baseava apenas nos princípios religiosos, mas também em um contrato, estabelecendo o alicerce da ideia dos direitos e da racionalidade. Esse movimento em direção ao Estado racional demonstrou a alteração da dominação tradicional do Estado absoluto para o início da dominação racional-legal do Estado liberal.

\subsubsection{O Estado liberal}

Segundo Bresser-Pereira (2009), o Estado liberal tem sua primeira manifestação na luta da burguesia pelos direitos e liberdades civis, face ao uso arbitrário do poder pelos governantes. Destacaram-se dessas lutas três revoluções liberais, quais sejam, a inglesa, a norte-americana e a francesa. A Revolução Francesa transferiu o poder político da antiga aristocracia para a burguesia emergente, isto é, houve a transferência de poder de um grupo dominante para outro, nesse caso, da nobreza para a burguesia. Com a consolidação do capitalismo industrial e o liberalismo clássico, fenômenos políticos essenciais, a prática clientelista adotada pelo monarca e pelo parlamento deixou de ser uma estratégia política central.

Com a instituição do Estado liberal e a teoria do contrato social, a legitimidade divina dos dirigentes políticos foi suprimida e a revolução capitalista (mercantil, industrial e liberal) alterou a forma de apropriação do excedente econômico, diminuindo a dependência do controle do Estado na realização de lucros no mercado. Além disso, essas mudanças fizeram com que as pessoas passassem de súditos a cidadãos, em uma nova forma de organização política, que, inicialmente, era amorfa, mas foi lentamente se transformando e se organizando como sociedade civil.

Quando os regimes autoritários deixaram de ser uma condição fundamental para a sobrevivência das classes dominantes, ocorreu a transição do Estado liberal para o Estado liberal-democrático, legitimado com a implantação do sufrágio universal. Porém, a democracia liberal se apresentou de forma elitista, com a detenção de poder restrita apenas aos grupos burgueses (BRESSER-PEREIRA, 2009).

Esses fatos históricos contribuíram para o surgimento do Estado liberal-democrático. A democratização começou a se firmar após a consolidação do capitalismo como modo dominante de produção e o fim do poder político de origem divina. Assim, “[...] os direitos civis vieram a

de um conjunto de regras, de um regime político ou de um governante. Abdicando da liberdade que possuiria no "estado de natureza" para obter os benefícios da ordem política. Ver Thomas Hobbes (1651), John Locke (1689) e Jean-Jacques Rousseau (1762). 
ser protegidos, mas a democracia estava distante, e a justiça social mais ainda" (BRESSERPEREIRA, 2009, p. 49).

\subsubsection{O Estado social-democrático}

De acordo com Bresser-Pereira (2009), a apropriação elitista do Estado liberaldemocrático gerou conflitos pelos ideais socialistas e pelos direitos sociais no século XX. A Grande Depressão de 1930 assinalou para a crise do Estado liberal-democrático e favoreceu a emersão de políticas de maior intervenção estatal na economia, para a manutenção dos direitos sociais, ou seja, gerou o sistema de bem-estar social. Com o surgimento do Estado socialdemocrático, a democracia deixou de ser apenas liberal e passou a ser, também, social ou plural. Dessa forma, o poder político se tornou "[...] menos concentrado em uma elite, e a opinião pública passava, pela primeira vez, a ter peso político" (BRESSER-PEREIRA, 2009, p. 79).

Com o êxito na promoção do crescimento econômico e da justiça social nos países desenvolvidos, ocorreram três processos históricos: a onda ideológica neoliberal, a crise do Estado e a globalização, movimentos que colocaram em xeque o Estado social-democrático. Assim, destacam-se três causas desses processos históricos: 1) a crise fiscal do Estado; 2) a crise no modo de intervenção do Estado e; 3) a crise na maneira burocrática de administrar o Estado. Segundo Bresser-Pereira (2009), essas crises abriram caminho para o surgimento do Estado social-liberal.

\subsubsection{O Estado social-liberal}

A concepção de Estado social-liberal surge pela convergência do entendimento de que é obrigatório que o Estado se comprometa com os direitos sociais e, também, com a liberdade individual e a coordenação de mercado. Segundo Bresser-Pereira (2009), é social porque compreende o socialismo não como um tipo de sociedade que compete com o capitalismo, mas como um sistema centrado na ideia de justiça social, como os princípios socialistas. É liberal devido a estar orientado para resguardar os bens sociais como a liberdade e o republicanismo. Em suma, sob esses princípios, o Estado social-liberal é um regime misto que mescla os aspectos positivos do liberalismo e do socialismo. Desse modo, o Estado social-liberal 
sociais e a promover o desenvolvimento econômico. Será liberal por que continuará a proteger a liberdade individual, usará mais o mercado e menos controles administrativos, executará seus serviços sociais e científicos sobretudo através de organizações públicas não-estatais de serviços competitivas, promoverá o capital humano e o desenvolvimento tecnológico de modo a permitir que as empresas comerciais sejam mais inovadoras e internacionalmente competitivas. Será social-liberal porque tornará os mercados de trabalho mais flexíveis, respeitando, ao mesmo tempo, os direitos sociais básicos, que são uma importante conquista socialista do século XX (BRESSER-PEREIRA, 2009, p. 160).

Para Bresser-Pereira (2009), o Estado republicano, diferentemente do Estado liberal, que defendia a liberdade política e econômica, sendo contrário ao forte controle do Estado na economia e na vida das pessoas, caracteriza-se pelo Estado forte na proteção dos direitos civis, sociais e políticos, também contrariando os neoliberais, que visavam uma agenda política internacional, pró liberalização do comércio, da abertura de mercados, da globalização, reduzindo o papel do Estado ao mínimo. Assim, ao garantir o Estado forte, garante os direitos civis que protegem a vida, a propriedade e a liberdade, bem como os direitos políticos a todos os cidadãos e, também, os direitos sociais, combatendo o desemprego e a desigualdade econômica. O Estado precisa ser capaz de assegurar os direitos republicanos (defender o patrimônio público, o Estado participativo, o controle social, as decisões democráticas) e contar com a participação política efetiva dos cidadãos. Em outras palavras, quando o Estado se torna mais racional, o interesse público é a orientação fundamental.

O Estado republicano é suficientemente forte para se proteger de controle privado, defendendo o patrimônio público contra o rent-seeking; é um Estado participativo, onde os cidadãos, organizados na sociedade civil, participam da definição de novas políticas e instituições e do exercício do controle social; é um Estado que depende de funcionários governamentais que, embora motivados por interesses próprios, estão também comprometidos com o interesse público; é um Estado com capacidade efetiva de reformar instituições e fazer cumprir a lei; é um Estado dotado de legitimidade necessária para tributar os cidadãos a fim de financiar ações coletivas decididas democraticamente; é um Estado, eficaz e eficiente no desempenho dos papéis dele exigidos. Resumindo, o Estado republicano é um sistema de governo que conta com cidadãos engajados que participam do governo juntamente com os políticos e os servidores públicos. (BRESSER-PEREIRA, 2009, p. 163).

Sendo assim, pode-se notar que o Estado social-liberal e o Estado Republicano são semelhantes, diferindo em sua capacidade de resguardar os direitos elementares e também os direitos republicanos, protegendo-os do controle e do interesse privado. Porém, a agenda neoliberal que visou à redução do papel do Estado, avançou rapidamente no Brasil no início 
dos anos 1990. A reforma gerencial da administração pública fez parte dessa agenda, propondo a privatização das empresas públicas e a terceirização dos serviços públicos. Todavia, conceitos como transparência e participação começaram a surgir na administração pública.

Bresser-Pereira (2009) afirma que será impossível a retomada do Estado neoliberal, pois não há mais apoio político ou fundamento econômico nem mesmo para voltar ao Estado liberal do século XIX. Contudo, em pleno ano de 2017, está claro que, ao contrário do pensamento de Bresser-Pereira (2009) em adotar mecanismos ou instituições para o desenvolvimento ou a construção do Estado republicano, observa-se, principalmente no Brasil, a retomada radical e impulsiva de uma agenda neoliberal com o apoio político e da classe dominante, com o objetivo exclusivo de suprimir os direitos sociais.

Em resumo, o Estado social-democrático surge pelo interesse da classe trabalhadora em particular, da classe média, e aumentou os bens sociais ${ }^{13}$. No Estado absoluto, os bens sociais eram o poder, a riqueza e a graça divina, ao passo que, no Estado liberal, as liberdades civis e a segurança são os principais bens sociais. No Estado liberal-democrático, destaca-se a igualdade política. Já no Estado social-democrático, a proteção social por meio da assistência à saúde, da educação básica gratuita, dos mecanismos de renda mínima e da seguridade social somam-se como importantes bens sociais (BRESSER-PEREIRA, 2009).

O Estado moderno terá a “[...] preocupação de proteger o homem do próprio homem e, para tal, o Estado deve ser o ator redutor de diferenças sociais, praticando uma verdadeira justiça distributiva" (COSTIN, 2010, p. 11). Porém, o papel do Estado como redutor das diferenças sociais, no ano de 2017, ainda segue bem distante do que foi escrito por Bresser-Pereira (2009) e Costin (2010).

As definições das formas do Estado moderno também direcionam para o desenvolvimento das formas de governo e, principalmente, da democracia, caracterizando-as. Sendo assim, os conceitos de democracia liberal, de democracia social e de democracia republicana ou participativa foram essenciais para conduzir às formas de como administrar o Estado. No entanto, antes de abordar os conceitos de democracia moderna, faremos a descrição resumida, da evolução das formas de governo.

\subsection{Formas de governo}

${ }^{13}$ Os bens sociais sãos os bens mais valorizados por uma dada sociedade (BRESSER-PEREIRA, 2009, p. 81). 
Esta seção apresenta os modelos de governo, que, recentemente, conduziram a regimes ditatoriais ou democráticos. Esses modelos, sobretudo no Brasil, influenciarão as reformas da administração do Estado. Os tipos mais comuns de governo são a monarquia (governo de um só), a aristocracia (governo de poucos) e a democracia (governo de muitos), sendo a democracia, atualmente, a mais vigente e questionável.

A vasta discussão sobre qual a melhor forma de governo não é recente. Ao longo dos séculos, os Estados vêm se adaptando ao que se considera ideal e alguns adotam as formas dos outros. Contudo, é inegável que a democracia é a forma de governo que mais se adaptou, em grande parte, às diferentes sociedades.

A democracia é um conceito muito antigo, assim como a monarquia e a aristocracia também o são. Suas concepções, apesar de simples, foram baseadas no critério de boa ou má. O primeiro relato sobre as formas de governo, segundo Bobbio (2002), foi registrado em $A$ história, de Heródoto, livro escrito no século VII antes de Cristo. A história é narrada por três persas, Otanes, Megabises e Dario, cada um defendendo o melhor modelo de governo para se adotar em seu país depois da morte de Cambises ${ }^{14}$.

Conforme Bobbio (2002, p. 40), Otanes, defendeu a democracia e destacou três pontos, sendo eles i) a distribuição dos cargos públicos pela sorte; ii) a necessidade dos magistrados prestarem contas de seus exercícios e; iii) as decisões estarem sujeitas ao voto popular. Megabises, por sua vez, defendeu a aristocracia e relatou que o poder deveria ser entregue a um grupo de homens escolhidos dentre os melhores, para que as melhores decisões fossem tomadas. Além disso, criticou a democracia como uma forma negativa, alegando que o povo não tem habilidades e competências para tomar decisões. Por fim, para Dario, a monarquia seria a melhor forma de governo, o que o levou a criticar a democracia e destacar que é impossível não haver corrupção nos negócios públicos, gerando-se uma sólida aliança entre os malfeitores para atuarem contra o bem comum.

A partir desse breve relato, é possível perceber os pontos positivos e negativos de cada modelo de governo na discussão entre os persas. Vale ressaltar que este foi um relato puramente imaginário de Heródoto, demonstrando pontos atuais a respeito da democracia. Demonstra a necessidade de que todas as decisões se sujeitem ao voto popular, pois, indubitavelmente, um processo participativo para as tomadas de decisões mais importantes pela sociedade através do voto popular, serão mais eficazes.

\footnotetext{
${ }^{14}$ Rei da Pérsia entre 530 a.C. e 522 a.C, considerado um tirano.
} 
No que se refere aos aspectos negativos apontados sobre a democracia, destaca-se a persistência e legitimação da deturpação da forma democrática, consequências da má formação do caráter, ausência de espírito republicano e da aliança de malfeitores que malversam e desviam o dinheiro público. Infelizmente, aspectos da democracia discutidos de forma imaginária séculos antes de Cristo ainda persistem em sua pior forma nos governos modernos.

As formas de governos - democracia, aristocracia (oligarquia) e monarquia - relatadas por Heródoto, com o tempo, desenvolveram-se em análises mais complexas e algumas derivações. Segundo Bobbio (2002), ao escrever sobre as formas de governo, Platão considerou a monarquia e a aristocracia como constituições ideais, definindo-as como leis fundamentais do Estado, não podendo ser alteradas. O filósofo descreveu, ainda, as formas que considerava corrompidas, a saber, a oligarquia, a democracia e a tirania. Assim, o critério da melhor para a pior forma de governo foi o da violência e do consenso, da legalidade e da ilegalidade. Desse modo, a forma ideal é caracterizada pela ausência de violência, pela vontade ou consentimento dos cidadãos e pela atuação de acordo com as leis estabelecidas, e não arbitrariamente.

De acordo com Bobbio (2002), Aristóteles estabelece como critérios "quem governa", determinado pela quantidade, e "como governa", definido pela qualidade. O filósofo considera a monarquia como governo bom de um só e a aristocracia como governo bom de poucos. Em contraponto, a democracia, a oligarquia e a tirania seguem como formas de governo consideradas ruins. Assim, a base de mensuração para distinguir a forma boa da forma má é a relação entre os que visam ao interesse comum e aqueles que objetivam apenas o interesse pessoal.

O bom governo, para Aristóteles, é baseado no interesse coletivo e não no interesse próprio. A orientação de governar de acordo com os interesses coletivos ainda segue com dificuldades de execução, pois é possível observar práticas que não visam ao interesse comum, mas, opostamente, governantes aguçados por seus próprios anseios, utilizando-se das instituições para satisfazer os próprios desejos em detrimento do coletivo, numa clara atuação de privatização do interesse coletivo.

Nota-se, portanto, que Platão e Aristóteles tinham em comum a necessidade de criar formas boas para contrariar as formas más, neste caso específico, a democracia. Ambos pensavam a democracia como forma de governo corrompida, negativa (BOBBIO, 2002).

A democracia passou a ser considerada como uma forma boa de governo com Políbio. Os critérios adotados por Políbio para definir a forma boa e a forma má foram a contraposição do governo baseado na força e o governo fundamentado no consenso e a comparação entre governo ilegal (arbitrário) e governo legal. Ao definir as três formas boas e as três formas más, 
desenvolveu um esquema completo, embora rígido. Assim, Políbio criou a teoria dos ciclos, isto é, a monarquia (forma boa) se degenera e vira tirania (forma má), que, por sua vez, degenera-se e transforma-se em aristocracia (forma boa); esta se degenera em oligarquia (forma má) e de oligarquia se converte em democracia (forma boa), de modo que a degradação das constituições chega à fase final, que é a oclocracia (forma negativa da democracia). Por fim, a degeneração da oclocracia volta diretamente à monarquia e assim sucessivamente (BOBBIO, 2002, p. 67).

No momento histórico em questão, tem-se o surgimento da teoria dos ciclos, e a democracia é tratada como uma forma boa de governo, isto é, quando o governo de muitos é bom, o Estado terá uma forma de governo democrática. Para concluir, tem-se o surgimento do governo misto, assim considerado devido ao enredamento entre as formas de governo.

\subsubsection{Teoria do governo misto}

De acordo com Bobbio (2002), o governo misto serviu para que as constituições se tornassem mais estáveis, pois as formas consideradas simples (boas e más) tinham breve duração e estavam destinadas, pela própria natureza, a se transformar numa forma diferente. A excelência do governo misto estava em encontrar mecanismo de controle recíproco dos poderes, ou no princípio do "equilíbrio". Segundo Bobbio (2002), para Maquiavel, o governo misto levou à instituição dos tribunos do povo, alcançando a perfeição, e servindo para mediar o conflito entre partidos antagônicos, o que garantiu a durabilidade da constituição como a liberdade interna dos cidadãos.

Assim, o governo misto surgiu do enredamento das formas de governo, pois elas não são necessariamente adotadas em seus modelos categorizados como ideais. Segundo Bobbio (2002), Políbio descreveu essa forma de governo como a melhor de todas enquanto síntese das três formas boas. O governo misto é uma constituição que mescla as três formas clássicas e que

[...] consiste no fato de que o rei está sujeito ao controle do povo, que participa adequadamente do governo; este, por sua vez, é controlado pelo senado. Como o rei representa o princípio monárquico, o povo o princípio democrático e o senado o aristocrático, o resultado dessa combinação é uma nova forma de governo. (BOBBIO, 2002, p. 70).

O governo misto passou a ser constituído pelas três formas de governo (monarquia, aristocracia e democracia), adotando parcialmente cada uma delas em uma mesma constituição. 
Porém, a crítica a este tipo de governo é devida à indivisibilidade da soberania, que impossibilita a divisão de poder entre o príncipe, os senhores e o povo. Tendo em vista que o poder soberano consiste eminentemente na capacidade de fazer leis, a classe que detiver esse poder definirá a forma de governo. Para exemplificar, quando o povo não tem poder de legislar, o Estado não é misto, mas, se esse poder pertencer ao senado, então o Estado será aristocrático; se pertencer ao rei, ele será monárquico; e se pertencer ao povo, ele será democrático. Uma das partes sempre se sobressairá às outras, caso contrário, o Estado rapidamente se precipitaria num conflito destrutivo de sua unidade, e da própria natureza de Estado (BOBBIO, 2002).

No entanto, o governo misto não surgiu da exigência de dividir o poder único do Estado, mas, pelo contrário, da imposição de compor numa unidade as diversas classes que constituem uma sociedade complexa. Assim, as variadas interpretações das constituições baseiam-se na presença concomitante de “[...] órgãos monocráticos e de órgãos colegiados, de colegiados restritos e representativos da maioria do povo" (BOBBIO, 2002, p. 101).

\subsubsection{Modelo bipartite de governo e a separação de poderes}

Segundo Bobbio (2002), a partir de Maquiavel, alterou-se o método do modelo tripartite dos tipos de governo (monarquia, aristocracia e democracia), passando a ser um modelo bipartite, dividido em principados e repúblicas. O principado "[...] corresponde ao reino; a república, tanto à aristocracia como à democracia" (BOBBIO, 2002, p. 83). Entre as repúblicas, pode-se destacar as repúblicas aristocráticas, que são governadas por poucos, e as repúblicas democráticas que são governadas por muitos, ou seja, quando o poder reside na vontade de um só, trata-se de um principado; quando reside numa vontade coletiva, que se manifesta em colegiado ou assembleia, tem-se a república.

Bobbio (2002) afirma que Maquiavel criticou os critérios desenvolvidos pelos seus antecessores ao definirem a forma boa e má, alegando que as tipologias de governo eram igualmente desvantajosas, pois as formas consideradas boas não são estáveis e as formas consideradas más pelo princípio de corrupção que contêm. As formas de governos seriam, então, a república, a monarquia e o despótico. O despotismo é a forma corrompida da monarquia, visto que o governo monárquico respeita as leis e o despótico as desrespeita.

Segundo Bobbio (2002), para Montesquieu, o governo republicano é aquele no "qual todo o povo, ou pelo menos uma parte dele, detém o poder supremo" (BOBBIO, 2002, p. 130); já o monárquico é aquele em que se governa de acordo com leis fixas e estabelecidas.

A comparação entre o governo misto polibiano e o governo moderado de Montesquieu 
mostra que o governo misto, ao mesclar as formas de governo, caracterizou a distinção entre Estado e governo e definiu a soberania como indivisível. Contrapondo-se ao governo moderado de Montesquieu, o governo misto é derivado das três formas clássicas de governo, ao passo que o governo moderado é a dissociação do poder soberano e da sua partição com base nas três funções fundamentais do Estado, quais sejam, a legislativa, a executiva e a judiciária (BOBBIO, 2002).

A separação de poderes derivou da convicção de que, para evitar o abuso do poder, este deve ser distribuído de modo que o poder supremo "[...] seja consequência de um jogo de equilíbrio entre diversos poderes parciais, e não se concentre nas mãos de uma só pessoa" (BOBBIO, 2002, p.136). Contudo, quando os poderes se associam, isto é, unem-se na mesma pessoa ou no mesmo corpo de magistrados, como, por exemplo, quando o poder legislativo se liga ao executivo, estes acabam por promulgar leis arbitrárias. Da mesma maneira, se o poder judiciário se unifica com o poder legislativo, o poder sobre a vida e a liberdade dos cidadãos é arbitrário, já que o juiz seria, ao mesmo tempo, legislador. Por fim, se o judiciário se unir ao executivo, o juiz pode ter a força de um opressor (BOBBIO, 2002).

Portanto, as democracias necessitam da clara separação entre os poderes, respeitando-se a autonomia existente entre eles a fim de evitar a concentração do poder na mão de uma pessoa, ou de um grupo. Sendo assim, é fundamental a clareza das regras das funções dos poderes para evitar disfunções e o fim da liberdade.

\subsubsection{Regimes ditatoriais}

No Brasil, as principais reformas da administração pública ocorreram em períodos ditatoriais, principalmente a reforma burocrática que se iniciou no governo ditatorial de Vargas e o DL 200/1967, que aconteceu no governo militar. Nesse contexto, faz-se necessário expor os conceitos de ditadura.

Conforme Bobbio (2002) o termo ditador era utilizado, antigamente, quando um indivíduo era nomeado ditador por um dos cônsules em circunstâncias extraordinárias, como uma guerra ou rebelião. Devido à excepcionalidade da situação, o ditador recebia poderes extraordinários, que consistiam, sobretudo, no desaparecimento da distinção dos limites "constitucionais", tendo como objetivo momentâneo resolver os problemas para os quais foi nomeado como responsável, não devendo exceder o período de seis meses.

Ao comparar a ditadura com a tirania e o despotismo, Bobbio (2002) destaca que a tirania é monocrática e tem poderes extraordinários, mas é ilegítima e não necessariamente temporária. 
O despotismo é monocrático, tem poderes excepcionais, é legítimo, mas não é temporário, pelo contrário, é um regime de longa duração. Assim, as três formas têm em comum o caráter monocrático e absoluto do poder, sendo que a tirania e a ditadura diferem no que tange à legitimidade. O despotismo e a ditadura diferem no que diz respeito ao fundamento de legitimidade.

Segundo Bobbio (2002). o termo ditadura ganha destaque quando Karl Marx argumenta que a melhor forma de governo é aquela que acelera a extinção do Estado e que permite a transformação da sociedade estatal em sociedade não-estatal. Nessa concepção, Marx se utilizou do conceito de "ditadura do proletariado" como uma forma de governo que consiste na transição da presença de Estado para a ausência de Estado. Para Bobbio (2002), Marx define o Estado como representante de uma classe social mais poderosa, economicamente dominante, para tornar-se, também, politicamente dominante e explorar a classe oprimida (proletariado). Assim, Marx descaracterizou as formas de governo anteriormente empregadas, apresentando uma concepção negativa do Estado, ou seja, analisando a atuação do Estado como uma forma má e de interesses de um grupo minoritário elitista para a sua manutenção.

Da descaracterização do Estado, surgiram os conceitos de ditadura do proletariado e de ditadura da burguesia. Segundo Bobbio (2002), a ditadura é um termo utilizado para indicar um governo absoluto, exclusivo, pessoal, moral e juridicamente condenável. Como exemplo, podem-se citar alguns governos como o fascismo italiano, o nacional-socialismo (nazismo) alemão, o stalinismo, o do general Pinochet (Chile) e a ditadura militar no Brasil, nos quais o regime constitucional precedente é afastado pelo uso da força por parte de um grupo armado e, após a conquista do poder por esse grupo, o governo continua a ser exercido com base na violência, suprimindo todas as liberdades civis e políticas.

\subsubsection{Democracia moderna}

Atualmente, a forma de governo predominante é a democracia. Observa-se constantemente o uso da palavra democracia, tanto pelos líderes políticos como pela sociedade. Há, ainda, quem questione e defenda sua ineficácia e peça o seu fim e, além disso, a ausência de clareza em tratar essa forma de governo, tanto pela elite política quanto pela sociedade, traz equívocos, distorções e, principalmente, disfunções em seu desenvolvimento.

A democracia moderna desenvolveu novos conceitos que foram introduzidos devido à sua complexidade, alterando sua forma inicial. Nos últimos anos, surgiram conceitos como democracia representativa, democracia deliberativa e, também, democracia republicana, 
conceitos estes que descrevem as tipologias da democracia moderna.

Segundo Bresser-Pereira (2009, p. 65), dois fatores foram essenciais para o desenvolvimento da democracia moderna. O primeiro foi a ação de delegar poder ao povo, deixando de constituir uma sociedade amorfa e gradualmente se transformando em sociedade civil. Já o segundo foi a evolução do capitalismo, que mudou a relação de apropriação do excedente econômico, que deixou de depender do Estado e passou a depender da realização de lucros no mercado. Assim, os regimes autoritários deixaram de ser uma condição fundamental para a sobrevivência das classes dominantes.

A democracia é o regime constitucional que garante o estado de direito; a liberdade de associação, de expressão e de informação; o direito universal de votar e ser eleito, e os direitos das minorias, e no qual os membros do governo são regularmente escolhidos de acordo com a regra da maioria, através de eleições livres e competitivas. (BRESSER-PEREIRA, 2009, p.77).

A democracia moderna que começou, paulatinamente, a se tornar o bom Estado, na medida em que demonstrou ser o sistema que mais garantiria a estabilidade política ou a ordem social, passando a ser, também, o regime que melhor atendia aos interesses de ricos e pobres. (BRESSER-PEREIRA, 2009).

Com o desenvolvimento do Estado moderno, a democracia acompanhou as transformações e se modificou. Quando o Estado moderno se tornou liberal, desenvolveu-se a democracia liberal. O mesmo ocorreu com o Estado social, fazendo surgira democracia social e, por fim, com o desenvolvimento do Estado republicano, tem-se o advento da democracia republicana. Essas alterações nas características da democracia também foram essenciais para alterar a forma de administrar o Estado.

Para Bresser-Pereira (2009), a democracia liberal garantiu a consolidação do sufrágio universal, de criação de partidos políticos competitivos, eleições regulares, representação e responsabilização política somente nas eleições. No entanto, no período em questão, a democracia foi caracterizada como elitista, pois não era preciso prestar contas aos eleitores. Porém, com as alterações na forma de a sociedade se organizar, principalmente através dos sindicatos e de outras organizações corporativas que representavam seus interesses, os cidadãos começaram a ter influência nas decisões políticas e, assim, surgiu a democracia social ou pluralista.

A democracia social preservou os aspectos centrais da democracia liberal, como, por exemplo, as eleições regulares, os partidos políticos competitivos, a representação, a proteção dos direitos civis e dos direitos políticos. Todavia, com o aumento do poder político dos 
sindicatos e de outras organizações corporativas, as negociações e os compromissos tornaramse uma prática central, acentuando a influência da opinião pública, exigindo-se cada vez mais a responsabilização dos políticos e a proteção dos direitos sociais (BRESSER-PEREIRA, 2009).

Segundo Bresser-Pereira (2009), a preocupação com a proteção dos direitos sociais, civis e políticos marcou a transição da democracia liberal para a democracia social. Na realidade, tanto a democracia liberal quanto a democracia social deram pouco enfoque aos pobres, servindo a democracia liberal para preservar interesses da elite, ao passo que a democracia social era utilizada para tirar um pouco do poder dessa elite, focando nos direitos sociais reivindicados pela classe média e legitimando sua influência política sobre a formulação das políticas e instituições públicas, enquanto para os pobres, restou apenas uma influência moderada, ainda que perceptível.

No entanto, no final do século XX, a crescente presença de organizações de controle social no âmbito da sociedade civil indicou claramente que os regimes democráticos nas sociedades mais avançadas e também nos países em desenvolvimento, como o Brasil e a Índia, atingiram uma nova fase de mudanças (BRESSER-PEREIRA, 2009, p. 185). Como a ampliação do debate público passou a ser o foco, surgiram novas formas de caracterizar a democracia, dando origem à democracia participativa e à democracia deliberativa, ou, como sugeriu BresserPereira (2009), à “democracia republicana”.

A democracia participativa consolidou-se ao ser reconhecida pelo sistema jurídico nas organizações da sociedade civil, adquirindo legitimidade política com os interlocutores políticos. Assim, desenvolveram-se formas de participação e práticas de democracia direta, como, por exemplo, a destituição dos ocupantes de cargos eletivos pelo voto e o orçamento participativo, práticas que ocorrem até hoje.

$\mathrm{O}$ atual contexto da democracia constitui-se do aperfeiçoamento e desenvolvimento de mecanismos de participação, mas ainda estamos distantes das práticas deliberativas. A democracia participativa, conforme a análise feita por Carole Pateman, envolve a socialização por meio da participação, ou seja, o local de trabalho ou a indústria, como instituição política, deve ser democratizado. A diferença entre a democracia participativa e a democracia deliberativa corresponde a cinco aspectos, sendo eles:

1. A deliberação deve ser livre, significando que os participantes estão obrigados apenas pelos resultados de sua deliberação; 2 . A deliberação deve ser "justificada", no sentido de que as partes devem declarar seus motivos para apresentar, apoiar ou criticar propostas; 3. A deliberação deve ser 
"formalmente igual" significando que os procedimentos não distinguem os participantes; 4. A deliberação deve ser "substantivamente igual": "os participantes são substantivamente iguais no sentido de que a distribuição existente de poder e recursos não determina as suas chances de contribuírem para a deliberação"; 5. A deliberação ideal objetiva chegar a um consenso, racionalmente motivado. (COHEN apud BRESSER-PEREIRA, 2009, p. 190, grifos do autor).

Um dos pontos ideais da democracia deliberativa é atingir a um consenso, racionalmente motivado. Porém, quando não o atinge, é possível que haja a necessidade de compromissos e votações. Algumas críticas à democracia deliberativa de Cohen partem das duas exigências dos itens 4 e 5, isto é, que os participantes sejam substancialmente iguais e que cheguem a um consenso, contudo, essas críticas não são realistas e, por isso, derivam em boa parte do idealismo ou da falta dele. Sendo assim, a democracia participativa e a democracia deliberativa são quase sinônimas, sendo que os arranjos deliberativos são formas ampliadas de democracia, ou seja, a democracia deliberativa é uma forma de organização mais avançada, na qual seus participantes têm as mesmas condições de opinar e votar (BRESSER-PEREIRA, 2009).

De acordo com Bresser-Pereira (2009), a democracia republicana tem seus conceitos mais modestos e baseados na inspiração em uma tradição latino-americana e católica de pensamento político e social, usando o orçamento participativo como exemplo de democracia participativa. A experiência é uma dentre outras inovações institucionais, e se estabeleceu na constituição de 1988, com vários mecanismos que ressaltam as formas de democracia participativa ou controle social. A democracia se baseia na participação dos cidadãos no processo político e, através desse princípio, “[...] tentar[á] construir o Estado republicano e a democracia republicana" (BRESSER-PEREIRA, 2009, p. 193).

A democracia republicana idealizada por Bresser-Pereira (2009) começou a se desenvolver quando os trabalhadores se tornaram mais organizados em suas agremiações e, também, quando as coalizões políticas de centro-esquerda começaram a vencer as eleições em vários países europeus. Esse movimento consolidou o Estado social-democrático e objetivou garantir os direitos sociais. Consequentemente, com a crescente força das organizações de controle social, que lutou por uma interpretação do interesse público, exigiu-se da democracia uma maior participação.

O conceito republicano utilizado por Bresser-Pereira (2009) rompe com os velhos traços da ideologia aristocrática, tendo como base princípios democráticos (participativo) e progressistas, divergindo do liberalismo econômico que, ainda hoje, preserva traços elitistas e conservadores. $\mathrm{O}$ enfrentamento do republicanismo antigo com o liberalismo foi motivado pela 
luta pela liberdade, porém, ambos rejeitavam a democracia como esta é entendida atualmente. No entanto, o sufrágio universal tornou-se realidade quando as elites perceberam que os pobres não representavam ameaças à ordem social, mas respeitariam os direitos de propriedades e contratos.

Dessa maneira, as sociedades capitalistas não tiveram alternativas a não ser a aceitar a democracia moderna e o sufrágio universal. Assim, as formas "[...] mais avançadas de democracia existentes estão ainda longe da democracia efetivamente deliberativa, mas estão também longe do modelo clássico de democracia liberal" (BRESSER-PEREIRA, 2009, p. 188). Portanto, Bresser-Pereira (2009), ao propor chamar de democracia republicana, tentou oferecer uma visão de como fortalecer o Estado por meio da participação ativa das organizações da sociedade civil.

Atualmente, a democracia moderna está presente na maioria dos países, algumas cada vez mais próximas da deliberativa, enquanto outras seguem estagnadas ou claramente ameaçadas por golpes neoliberais para manutenção de um pensamento político-social que não condiz com o papel do Estado moderno. Desenvolver a democracia é fundamental para os teóricos políticos, sobretudo, em termos práticos, a democracia participativa ou, normativamente, a democracia deliberativa. Porém, ainda há muita resistência, principalmente em reconhecer a possibilidade de existência de "[...] um grande número de cidadãos republicanos orientados para o interesse público e comprometidos com a participação, ainda que limitada, nos assuntos públicos" (BRESSER-PEREIRA, 2009, p. 194).

A consolidação da democracia social ou pluralista nos países avançados encontrou um novo problema, a necessidade de aperfeiçoar, tornando-a representativa. O imperativo de se desenvolver para melhorar a representação será possibilitado através das transformações institucionais, bem como aumentando o papel das organizações no processo político. No entanto, quando os governos não usam as organizações da sociedade civil como ferramenta de controle da administração, “[...] a capacidade das comunidades de se organizarem é limitada. Quando os governos as usam, temos sinais de reforma da gestão pública" (BRESSERPEREIRA, 2009, p. 202).

Bresser-Pereira (2009) faz uma análise das formas da democracia moderna traçando uma evolução linear. Ausentaram-se as possibilidades de conceitos democráticos instituídos serem suprimidos e de uma análise de democracia imperfeita, inacabada, evoluindo para uma forma perfeita, para um modelo ideal. Segundo Morin (2000, p. 110), não existem apenas democracias imperfeitas, mas estão em curso os "processos de regressão democrática" que afastam o indivíduo das decisões políticas, com a argumentação de que eles não têm "competências" para 
questões "complicadas", que devem ser tomadas e decididas pelos "espertos", isto é, pelos tecnocratas, o que começa a "[...] atrofiar competências, a ameaçar a diversidade e a degradar o civismo" (MORIN, 2000, p. 110). Esses fatores ocorrem devido à crescente complexidade dos problemas e à forma "mutiladora" como estão sendo tratados. Assim, a política "[...] fragmenta-se em diversos campos e a possibilidade de concebê-los juntos diminui ou desaparece" (MORIN, 2000, p. 110).

Desse modo, isso é o que de fato vem ocorrendo na democracia moderna, demonstrando sua regressão, e ocorre devido à expulsão dos cidadãos do campo político para serem cada vez mais dominados pelos tecnocratas. Esse domínio da "nova classe" refuta efetivamente a democratização do conhecimento. Nesse contexto, a prática da regressão da democracia reduz o

[...] político ao técnico e ao econômico, a redução do econômico ao crescimento, a perda dos referenciais e dos horizontes, tudo isso conduz ao enfraquecimento do civismo, à fuga e ao refúgio na vida privada, a alternância entre apatia e revolta violenta e, assim, a despeito da permanência das instituições democráticas, a vida democrática se enfraquece. (MORIN, 2000, p. 112)

Esses conceitos de organização do Estado, de governo e de democracia moderna supracitados serão essenciais para o desenvolvimento da administração, criando-se modelos de acordo com o momento organizacional de cada Estado.

\subsection{Modelos de administração do Estado}

A Administração Pública representa o aparelhamento do Estado e funciona como o "[...] instrumento do governo para planejar; organizar, dirigir e controlar todas as ações administrativas, no sentido de dar plena e cabal satisfação das necessidades coletivas básicas" (CHIAVENATO, 2008, p. 116). Para Chiavenato (2008), o progresso e o desenvolvimento de uma nação passam, obrigatoriamente, pela administração. Assim, os componentes básicos do setor público são o Estado, o governo e a administração pública.

É importante ressaltar a diferença entre Estado e aparelho do Estado, a fim de distinguir a Reforma do Estado da Reforma do Aparelho do Estado. Assim, tem-se que

A reforma do Estado é um projeto amplo que diz respeito às várias áreas do governo e, ainda, ao conjunto da sociedade brasileira, enquanto que a reforma do aparelho do Estado tem um escopo mais restrito: está orientada para tomar 
a administração pública mais eficiente e mais voltada para a cidadania. (CHIAVENATO, 2008, p. 122).

Esta pesquisa descreverá a reforma do aparelho do Estado e, para isso, partirá do pressuposto de que o projeto de Estado é condizente com a sociedade. Ao tratar das reformas administrativas executadas pelo Poder Executivo e da influência dos conceitos de forma de Estado e de governo através da dominação burocrática, demonstrará como a administração pública se desenvolveu para se adaptar às transformações exigidas por sua época ou pelo "espírito" do seu tempo.

Com os avanços do Estado moderno, nota-se certa intensidade em desenvolver os modelos de administrar, que se tornaram importantes para dar respostas às demandas dos grupos dominantes. A primeira definição de administrar o Estado apareceu no período do Estado absoluto e ficou conhecida como administração patrimonialista. Basicamente, a administração patrimonialista se caracterizou por tratar dos interesses privados acima dos interesses público, ou seja, o Estado era adequado a fins particulares. Diante da chegada do Estado liberal, a administração pública necessitou se desenvolver e passou a ser chamada de burocrática. Esse modelo de administração tinha como objetivo garantir os direitos civis e políticos, tornando-se racional, isto é, extinguindo os interesses privados para desenvolver o interesse público. Por fim, com o avanço do Estado social-liberal, surgiu a concepção de administração gerencial ou nova gestão pública. $\mathrm{O}$ modelo gerencial visou dinamizar a administração do Estado com foco na participação, transparência e controle social (BRESSER-PEREIRA, 2009).

Quadro 2 - Tipos históricos de Estado segundo regime político, administração e democracia

\begin{tabular}{|c|c|c|}
\hline Regime político & Administração & Democracia \\
\hline Estado absoluto & Administração patrimonial & - \\
\hline Estado liberal & Administração pública burocrática & - \\
\hline $\begin{array}{l}\text { Estado liberal- } \\
\text { democrático }\end{array}$ & Administração pública burocrática & Democracia liberal ou elitista \\
\hline $\begin{array}{c}\text { Estado social- } \\
\text { democrático (do bem- } \\
\text { estar social) }\end{array}$ & Administração pública burocrática & Democracia social ou pluralista \\
\hline $\begin{array}{l}\text { Estado social-liberal e } \\
\text { republicano }\end{array}$ & Gestão pública/gerencial & $\begin{array}{c}\text { Democracia republicana ou } \\
\text { participativa }\end{array}$ \\
\hline
\end{tabular}

Fonte: BRESSER-PEREIRA, 2009.

O quadro 2 demonstra as características do Estado moderno, das formas de governo, especificamente da democracia, e os tipos de administração. De acordo com Bresser-Pereira (2009), como é possível notar, quando se tem a democracia participativa, a administração do 
Estado será o modelo gerencial e o seu regime político, social-liberal, correspondente à sua evolução. Assim, faz-se necessário detalhar a evolução linear das formas de administrar o Estado, passando pelo modelo patrimonialista, burocrático e gerencial.

\subsubsection{Administração patrimonialista}

A chegada do Estado absoluto foi um acordo político para garantir os contratos entre a burguesia emergente e o monarca. A arrecadação de tributos também seria usada para manter uma aristocracia patrimonial dependente que vivia na corte, com a finalidade de cuidar da guerra, cobrar impostos e administrar a justiça. No entanto, a burguesia emergente e o monarca eram permeados de todo tipo de nepotismo e pela ausência de distinção entre o patrimônio público e o patrimônio privado.

Nesse período, a administração do Estado ficou conhecida como patrimonialista. Segundo Weber (2014), o tipo "ideal” de patrimonialismo está definido por meio de cinco aspectos básicos, a saber:

1) ausência de "competência" fixa segundo regras objetivas; 2) ausência de hierarquia racional fixa; 3) ausência de nomeação regulada por contrato livre e o ascenso regulado; 4) ausência de formação profissional (como norma); 5) (muitas vezes) ausência de salário fixo e (ainda mais frequentemente) o salário pago em dinheiro. (WEBER, 2014, p. 147).

Weber (2014) ao categorizar do modelo patrimonialista, descreve uma estrutura desregulada e desorganizada. Assim, a (1) ausência de competência e a (2) ausência de hierarquia fixa demonstra uma estrutura desorganizada. (3) A ausência de nomeação regulada, (4) a ausência de formação profissional e (5) ausência de salário fixo, apresenta uma organização informal, desregulada.

Dessa maneira, o tipo "ideal" é igualmente todos "[...] os poderes de mando e direitos senhorais econômicos, e as oportunidades econômicas privadas apropriadas" (WEBER, 2014, p. 157). A apropriação de poderes ocorre quando os senhorais judiciais ou militares se privilegiam de uma posição estatal, o que considerado apropriação patrimonial. A apropriação extrapatrimonial é a apropriação de oportunidades puramente econômicas (de domínio, tributos ou emolumentos). O patrimonialismo atua

a) pelas dificuldades que o tradicionalismo opõe à existência de estatutos formalmente racionais e com duração confiável, calculáveis, portanto, em seu 
alcance e aproveitamentos econômicos; b) pela ausência típica de um quadro de funcionários com qualificação profissional formal; c) pelo amplo espaço deixado à arbitrariedade material e vontade puramente pessoal do senhor e do quadro administrativo - esfera em que eventual corrupção, que nada mais é do que a degeneração do direito a taxas não regulamentadas, teria importância relativamente mínima, por ser praticamente calculável, se apresentasse uma magnitude constante e não um fator viável para cada funcionário. Em caso de arrendamento de cargos, o funcionário, para obter lucro de seu capital investido, vê-se imediatamente obrigado a aplicar meios de extorsão, por mais irracionais que sejam seus efeitos; d) pela tendência, inerente a todo patriarcalismo e patrimonialismo e consequência da natureza da vigência da legitimidade e do interesse de ver satisfeitos os dominados à regulação materialmente orientada da economia-por ideais "culturais" utilitários ou ético-sociais ou materiais - e, portanto, ao rompimento de sua racionalidade formal, orientada pelo direito dos juristas. (WEBER, 2014, p. 157).

Como se pode observar, o patrimonialismo é a apropriação do interesse público pelo grupo dominante que, através dessa apropriação do Estado, se mantém com cargos vitalícios, posições privilegiadas, taxas extraordinárias, subornos, presentes e, principalmente, exerce a prática do clientelismo. Portanto, o modelo patrimonialista atua apenas em atender aos interesses particulares do rei e do grupo aristocrático, podendo ser caracterizado como um período de regulação ausente, um Estado sem leis, de interesse privado, isto é, desregulado ${ }^{15}$.

\subsubsection{Administração burocrática}

$\mathrm{O}$ século $\mathrm{XIX}^{16}$ se caracterizou por grandes reformas, consagrando o capitalismo industrial e o liberalismo clássico, além de ser, também, o século da reforma burocrática, fazendo o aparelho do Estado assumir um caráter moderno e capitalista.

A reforma burocrática, de acordo com Bresser-Pereira (2009), foi política, pois sua motivação estava diretamente relacionada à ascensão do Estado de direito e do liberalismo clássico. Com essa orientação política, uma das práticas mais comuns no patrimonialismo, o clientelismo, deixou de ser uma estratégia de política central devido à conquista do direito de voto, que aumentou o número de eleitores, porém, o número de cargos burocráticos não aumentou proporcionalmente. Esse cenário inviabilizou o discurso clientelista e argumentos como a necessidade de concursos de admissão, de forma que um serviço público autônomo, baseado no mérito, começou a ganhar destaque. Desse modo, a reforma burocrática foi essencial para a modernização do Estado e politicamente inevitável.

\footnotetext{
15 Sobre esse aspecto, serão abordados mais detalhes no capítulo quatro.

${ }^{16}$ A partir de 1860, países como a França, Alemanha, Estados Unidos e Japão também investiram na formação de suas indústrias, consolidando a segunda Revolução Industrial.
} 
Para Weber (2014), a administração do Estado somente atingirá sua plenitude quando os quadros administrativos atingirem os seguintes aspectos, considerados como ideais: os funcionários individuais

1. São pessoalmente livres; obedecem somente às obrigações objetivas do seu cargo; 2. São nomeados (e não eleitos) numa hierarquia rigorosa de cargos; 3. Tem competências funcionais fixas; 4. Em virtude de um contrato, portanto, (em princípio) sobre a base de livre seleção, segundo a qualificação profissional - no caso mais racional: qualificação verificada mediante a prova e certificada por diploma; 5. São remunerados com salários fixos em dinheiro, na maioria dos casos com direito a aposentadoria; em certas circunstâncias (especialmente em empresas privadas), podem ser demitidos pelo patrão, porém sempre podem demitir-se por sua vez; seu salário está escalonado, em primeiro lugar, segundo a posição na hierarquia e, além disso, segundo a responsabilidade do cargo e o princípio da correspondência à posição social; 6. Exercem seu cargo como profissão única ou principal; 7. Têm a perspectiva de uma carreira: "progressão" por tempo de serviço ou eficiência, ou ambas as coisas, dependendo do critério dos superiores; 8 . Trabalham em "separação absoluta dos meios administrativos" e sem apropriação do cargo; 9. Estão submetidos a um sistema rigoroso e homogêneo de disciplina e controle do serviço. (WEBER, 2014, p. 144).

As definições de tipo "ideal" da administração burocrática enfatizaram a superioridade técnica sobre o patrimonialismo. Sob os objetivos de precisão, rapidez, univocidade, conhecimento da documentação, continuidade, discrição, uniformidade, subordinação rigorosa, diminuição de atritos e custos materiais e pessoais, atingem a perfeição da administração do Estado rigorosamente burocrático.

Segundo Weber (2014), uma burocracia plenamente realizada pertence aos complexos sociais mais dificilmente destrutíveis e é o meio específico por excelência para transformar uma “ação comunitária" (consensual) numa "ação associativa" racionalmente ordenada. Portanto, a burocracia weberiana possui o caráter racional, pois a regra, a finalidade, os meios, a impessoalidade "objetiva" dominam suas atitudes, caracterizando o avanço do racionalismo e a superação das formas estruturais irracionais.

Atualmente, Segundo Chiavenato (2008) a burocracia é vista como uma organização morosa e ineficiente, em que o papelório predomina. Também se emprega o termo burocracia para designar o apego dos funcionários aos regulamentos e rotinas, resultando na ineficiência da organização. Assim, a visão leiga passou a entender a burocracia por seus defeitos do sistema (disfunções) e não pelo sistema como um todo. A burocracia weberiana é exatamente o contrário, sendo uma organização eficiente por excelência e possuindo as seguintes características: 
1. Caráter legal das normas e regulamentos. 2. Caráter formal das comunicações. 3. Caráter racional e divisão do trabalho. 4. Impessoalidade nas relações. 5. Hierarquia de autoridade. 6. Rotinas e procedimentos padronizados. 7. Competência técnica e meritocracia. 8. Especialização da administração. 9. Profissionalização dos participantes. 10. Completa previsibilidade do funcionamento. (CHIAVENATO, 2008, p. 56).

As particularidades supracitadas são a base da burocracia weberiana, que influenciou as organizações como um todo, inclusive a administração pública. Porém, é importante destacar quais são suas vantagens e suas disfunções. As vantagens da burocracia constituem-se de:

1. Racionalidade em relação ao alcance dos objetivos da organização. 2. Precisão na definição do cargo e na operação, pelo conhecimento exato dos deveres. 3. Rapidez nas decisões, pois cada um conhece o que deve ser feito e por quem as ordens e os papéis tramitam através de canais preestabelecidos. 4. Univocidade de interpretação garantida pela regulamentação específica e escrita. Por outro lado, a informação é discreta, pois é fornecida apenas a quem deve recebê-la. 5. Uniformidade de rotinas e procedimentos que favorece a padronização, a redução de custos e erros, pois as rotinas são definidas por escrito. 6. Continuidade da organização por meio da substituição do pessoal que é afastado. Além disso, os critérios de seleção e escolha do pessoal baseiam-se na capacidade e na competência técnica. 7. Redução do atrito entre as pessoas, pois cada funcionário conhece o que é exigido dele e quais os limites entre suas responsabilidades e as dos outros. 8. Constância, pois os mesmos tipos de decisão devem ser tomados nas mesmas circunstâncias. 9. Confiabilidade, pois o negócio é conduzido através de regras conhecidas, e os casos similares são metodicamente tratados dentro da mesma maneira sistemática. As decisões são previsíveis e o processo decisório, por ser despersonalizado no sentido de excluir sentimentos irracionais, como amor, raiva, preferências pessoais, elimina a discriminação pessoal. 10. Benefícios para as pessoas na organização, pois a hierarquia é formalizada, o trabalho é dividido entre as pessoas de maneira ordenada, as pessoas são treinadas para se tomarem especialistas, podendo encarreirar-se na organização em função de seu mérito pessoal e competência técnica. (CHIAVENATO, 2008, p. 61).

No entanto, não existe nenhuma organização que siga totalmente o modelo racional ideal weberiano teorizado, já que o tipo ideal de burocracia sofre transformações quando operado por homens, o que torna possível verificar que as disfunções burocráticas são consequências não previstas.

No que se refere às disfunções da burocracia, são elas:

1. Internalização das regras e apego aos regulamentos 2. Excesso de formalismo e de papelório. 3. Resistência às mudanças. 4. Despersonalização do relacionamento. 5. Categorização como base do processo decisório. 6. Superconformidade às rotinas e aos procedimentos. 7. Exibição de sinais de autoridade. 8. Dificuldade no atendimento a clientes e conflitos com o público. (CHIAVENATO, 2008, p. 62) 
As disfunções supracitadas compõem os desafios a serem superados quando a administração pública começar o processo pós-burocrático, ao adotar práticas consideradas gerenciais. Em suma, tem-se uma organização fundamentada no racionalismo e no formalismo, sendo descrita pelas consequências previsíveis da burocracia. As consequências imprevistas levam a burocracia à ineficiência e às imperfeições. Portanto, as disfunções da burocracia causadas pela operabilidade dos homens fizeram com que a administração do Estado entrasse na fase pós-burocrática, dando seguimento à adoção do modelo gerencial.

\subsubsection{Administração gerencial}

As constantes crises do Estado capitalista, a partir dos anos 70, sobretudo com o início da crise do petróleo (1973), demonstrava indícios de esfacelamento do Estado sob três dimensões, a econômica, a social e a administrativa, que se interligavam entre si. Segundo Abrucio (apud BRESSER-PEREIRA; SPINK, 2006), a primeira dimensão é a keynesiana, conhecida pela intervenção estatal na economia, que visa garantir o pleno emprego e atua em setores considerados estratégicos para o desenvolvimento nacional, como, por exemplo, o setor de telecomunicações e o de petróleo. A segunda dimensão é representada pelo Welfare State, que tem como objetivo primordial a produção de políticas públicas na área social e o objetivo de garantir o atendimento das necessidades básicas da população. A terceira dimensão consiste no funcionamento interno do Estado, conhecido como burocrático, focando em manter a impessoalidade, a neutralidade e a racionalidade do aparato governamental.

A crise da economia mundial foi caracterizada por um grande período de recessão. Esse momento de escassez afetou sobremaneira os Estados, fazendo-os entrar numa grave crise fiscal. A crise do Estado, que se encontrava com os recursos escassos e os déficits altos, afetou a organização das burocracias públicas, principalmente as despesas com gastos de pessoal.

Os enfrentamentos das crises consistiram em adotar políticas de redução de custos que atingiram diretamente a administração do Estado. Tais medidas visaram a redução de gastos com pessoal e na necessidade de aumentar a eficiência governamental. Segundo Abrucio (apud BRESSER-PEREIRA; SPINK, 2006), seria necessária uma transformação profunda na burocracia weberiana, que se apresentava como um modelo muito lento e excessivamente apegado às normas considerado ineficiente.

Um ponto importante a se destacar diz respeito ao fato de o modelo burocrático vigente na época ser qualificado mais como "[...] um grupo de interesse do que como um corpo técnico 
neutro a serviço do cidadão" (ABRUCIO apud BRESSER-PEREIRA; SPINK, 2006, p. 177). Assim, são geradas disfunções como as relações clientelistas e corporativas mantidas pelo corpo burocrático. Além disso, também ganha força o sentimento antiburocrático, presente em boa parte da opinião pública, que ainda se mantém, comparando-se com o setor privado, detentor de um modelo "ideal" de gestão.

A burocracia weberiana, definida como tipo ideal, passou a ser classificada como um modelo administrativo antigo e, basicamente, como uma "[...] organização guiada por procedimentos rígidos, forte hierarquia e total separação entre o público e o privado". (ABRUCIO apud BRESSER-PEREIRA; SPINK, 2006, p. 178). Esse movimento de sentimento contrário à burocracia estatal era favorável aos ideais da iniciativa privada. Diante do cenário da escassez de recursos públicos, do enfraquecimento do poder do Estado e dos avanços de uma ideologia privatizante, o modelo weberiano foi levado à crise. Nesse contexto, inicia-se a adoção de práticas conhecidas como gerenciais na administração pública.

O modelo gerencial passou por três fases, a primeira conhecida como gerencialismo puro, a segunda, como consumerism (consumidor/cliente) e a terceira, que é o modelo atual conhecido como Public Service Orientation (PSO).

Quadro 3 - Respostas as crises do modelo burocrático inglês (Whitehall)

\begin{tabular}{|c|c|c|}
\hline Gerencialismo puro & Consumerism & Public Service Orientation \\
\hline Economia/eficiência (produtividade) & Efetividade/qualidade & Accountability/equidade \\
\hline Tax payers (contribuintes) & Clientes/consumidores & Cidadãos \\
\hline
\end{tabular}

Fonte: Abrucio (apud BRESSER-PEREIRA; SPINK, 2006, p. 181).

Como é possível observar no quadro 3, destacam-se as características dos modelos gerenciais, porém, em verdade, há um enredamento, bem como um aprimoramento, entre elas. Desse modo, pode-se notar duas importantes constatações. A primeira concerne a uma mudança substancial, desde o gerencialismo puro até a public service orientation. E a segunda, a mais importante, é a de que, embora haja diferenças entre ambas, elas não são excludentes. Pelo contrário, percebe-se um aperfeiçoamento de uma para outra, desenvolvendo ou incluindo novos conceitos ao modelo gerencial (ABRUCIO apud BRESSER-PEREIRA; SPINK, 2006).

O modelo gerencial, em sua fase inicial, visou " [...] administrar a res publica de forma semelhante ao setor privado, de forma eficiente, com a utilização de ferramentas que consigam maximizar a riqueza do acionista, ou a satisfação do usuário" (CHIAVENATO, 2008, p.118). Assim, a primeira fase desse modelo centrou-se no incremento da eficiência, devido às 
consequências das disfunções do modelo burocrático. Nessa fase, os usuários dos serviços públicos são vistos como clientes, isto é, o financiador do sistema.

A segunda fase, o consumerism, concentra-se na busca pela qualidade, tratando os usuários dos serviços públicos como cliente consumidor. Nela, o foco organizacional é "[...] a burocracia, que normalmente é auto-referenciada, ou seja, voltada para si mesma, passa a observar com maior cuidado a razão de sua existência: a satisfação de seu consumidor." (CHIAVENATO, 2008, p. 119).

A terceira fase (PSO) enfatiza o conceito de cidadão, voltado para a consecução do bemcomum. Com isso, o que se busca é o tratamento igual a todos os que se encontram em situações equivalentes. Assim, além dos direitos, os cidadãos passam a ter obrigações pela fiscalização de atos praticados com inobservância da Legislação ou do interesse público.

\subsubsection{Gerencialismo puro}

O gerencialismo puro tinha como objetivo, devido à crise fiscal que ocorria, reduzir os custos do setor público e aumentar sua produtividade. As mudanças na burocracia encontravamse ao lado do projeto de reforma do Estado. As diretrizes que nortearam o gerencialismo puro foram a privatização de empresas nacionalizadas no pós-guerra, a desregulamentação e a devolução de atividades governamentais à iniciativa privada (ABRUCIO apud BRESSERPEREIRA; SPINK, 2006, p. 182).

Urgia reduzir os gastos públicos e aumentar a eficiência governamental, pois o momento era de grande escassez de recursos. Desse modo, o gerencialismo puro enfatizava o conceito de produtividade e a eficiência na administração do Estado.

Um dos objetivos era mudar o modelo burocrático weberiano, que se caracterizou como uma organização de “[...] estrutura rígida e centralizada, voltada para o cumprimento dos regulamentos e procedimentos administrativos e em que o desempenho é avaliado apenas com referência à observância das normas legais e éticas." (ABRUCIO apud BRESSER-PEREIRA; SPINK, 2006, p. 183). Para superar as disfunções burocráticas, o governo Thatcher propôs três objetivos:

1) a clara definição das responsabilidades de cada funcionário das agências governamentais; 2 ) a clara definição dos objetivos organizacionais, analisados em sua substância e não como processo administrativo; 3) maior consciência acerca do "valor de recursos" (value money) públicos, procurando maximizar a relação financeira entre os recursos iniciais e os gastos realizados para a produção de políticas, ou seja, incorporando o valor da eficiência na lógica de 
funcionamento burocrático. (ABRUCIO apud BRESSER-PEREIRA; SPINK, 2006, p. 183).

De acordo com Abrucio (apud BRESSER-PEREIRA; SPINK, 2006), para tornar eficazes esses objetivos, foram implementados determinados instrumentos gerenciais, como os mecanismos de racionalização orçamentária (para possibilitar o aumento da consciência dos custos no serviço público), a utilização de técnicas de avaliação de desempenho e controle orçamentário, mecanismos de responsabilidade para as agências governamentais e para os funcionários públicos. Na área organizacional, desenvolveu-se a administração por objetivos ${ }^{17}$, isto é, ao traçar objetivos claros de ação para as agências, possibilitou-se uma avaliação de desempenho baseada na comparação entre os resultados obtidos previamente determinados. Outra ação foi a descentralização administrativa, para dar maior autonomia às agências e aos departamentos.

O modelo de administração inglês ficou caracterizado como extremamente hierárquico, sendo contraposto por um modelo que delegava autoridade (empowerment) aos servidores (ABRUCIO apud BRESSER-PEREIRA; SPINK, 2006). A perspectiva do modelo gerencial era moldar os gerentes, desenvolver as habilidades e a criatividade e, dessa forma, encontrar novas soluções para aumentar a eficiência governamental. Com o passar do tempo, a expectativa era de que a medida institucional pudesse transformar a cultura burocrática.

A prioridade demasiadamente focada na estratégia de eficiência governamental centralizou-se somente nos critérios para aferir a eficiência, tornando-os tão rígidos quanto as regras e os procedimentos do modelo weberiano, causando ineficiência e incapacidade adaptativa, relegando, assim, outros valores, como a flexibilidade para decidir e inovar. Também não foi dada a devida importância à atribuição da avaliação da efetividade, deixandose de avaliar a qualidade do serviço público (ABRUCIO apud BRESSER-PEREIRA; SPINK, 2006).

A eficiência traz novamente à baila a importância do governo como prestador de bons serviços, demonstrando a qualidade do modelo gerencial. No entanto, ao levar para os usuários dos equipamentos sociais a responsabilidade de avaliar a qualidade dos programas, vem à tona a subestimação do conteúdo político da administração pública. Na realidade, o discurso do gerencialismo puro pregava a separação entre a política e a administração. Para Abrucio (apud BRESSER-PEREIRA; SPINK, 2006, p. 185), a "despolitização", aliada ao conceito de eficiência governamental, focado na busca da produtividade privada e na gestão empresarial

\footnotetext{
${ }^{17}$ Modelo inserido pela Administração Científica - Teoria Neoclássica.
} 
para o setor público, trouxe consequências que levou Christopher Pollitt (1990) a classificar o gerencialismo como "neotaylorismo", ou seja, não foi levado em consideração o fato de que as especificidades do setor público diferem daquelas da área privada, de modo que valores como equidade e justiça não puderam ser medidos ou avaliados pelos conceitos do gerencialismo puro.

Todavia, os avanços do gerencialismo puro sobre a questão financeira tornaram os ingleses mais conscientes dos recursos das políticas públicas (POLLITT, 1990). Esse valor serviu de base para que outros governos realizassem as reformas administrativas. Portanto, para aperfeiçoar o gerencialismo puro aos valores da administração pública, o modelo gerencial precisou se "[...] constituir de serviços públicos voltados para os anseios dos clientes/consumidores" (ABRUCIO apud BRESSER-PEREIRA; SPINK, 2006, p. 185). A adoção de práticas gerenciais tratando o usuário dos serviços públicos como clientes/consumidores ficou conhecida como consumerism.

\subsubsection{Modelo gerencial: Consumerism (clientes/consumidores)}

A redução dos gastos de forma arbitrária afetou mais a redução da qualidade dos serviços do que o aumento da produtividade. Tal situação ocorreu por dar ênfase apenas à mensuração da eficiência e não à efetividade dos serviços públicos (ABRUCIO apud BRESSER-PEREIRA; SPINK, 2006). Para sanar esse problema, a ausência de medição da efetividade dos serviços públicos, a administração pública britânica adotou como estratégia tratar seus usuários como consumidores. Assim, criou o programa Citizen's Chart, que priorizou a necessidade dos serviços públicos serem direcionados pelo público afetado. Segundo Abrucio (apud BRESSERPEREIRA; SPINK, 2006), com a implantação da avaliação de desempenho organizacional com base nos dados recolhidos junto aos consumidores, desenvolveu-se o modelo gerencial consumerism, que visou tratar os usuários dos equipamentos sociais como consumidores/clientes.

Para Abrucio (apud BRESSER-PEREIRA; SPINK, 2006), com o intento de atender a satisfação dos consumidores, o governo britânico adotou três medidas: 1) a descentralização; 2) a competição entre as organizações do setor público e; 3) a adoção de novo modelo contratual. A primeira medida tinha como objetivo deixar os serviços públicos mais próximos do consumidor, de modo que pudessem ser fiscalizados pela população. A segunda tratava-se de incentivar a competição entre os equipamentos sociais, pois, quanto mais competitivos, melhor seria a qualidade dos serviços, evitando o monopólio e, por conseguinte, haveria mais 
opções para o consumidor escolher o melhor equipamento. Por fim, a terceira visou adotar um novo modelo contratual para os serviços públicos dispondo-os em três dimensões:

1) extensão das relações contratuais ao fornecimento de serviços públicos entre o setor público, setor privado e o voluntário/não lucrativo, criando uma nova estrutura de pluralismo institucional, contraposta ao antigo modelo de monopólio estatal; 2) extensão das relações contratuais ao próprio setor público, envolvendo descentralização, delegação de autoridade e mecanismos de quasi market; 3) estabelecimentos de contratos de qualidade entre os prestadores de serviços e os consumidores/clientes (CLARKE, 1993 apud BRESSER-PEREIRA; SPINK, 2006, p. 87).

A implantação do novo modelo contratual gerou três pressupostos. O primeiro dizia que, com a ausência de recursos, a maneira mais viável para aumentar a qualidade era introduzir relações contratuais de competição e de controle. O segundo utilizava-se da forma contratual para evitar a situação de monopólio. E o terceiro versava sobre a possibilidade de avaliar e controlar o desempenho dos serviços públicos a partir do marco contratual (ABRUCIO apud BRESSER-PEREIRA; SPINK, 2006, p. 187).

Contudo, o maior problema do consumerism estava na relação entre o governo como prestador de serviços públicos e a população. Ao tratar os usuários dos serviços públicos como consumidores/clientes, estabeleceu a mesma relação que o setor privado praticava com seus consumidores/clientes. Essa relação é complexa e, segundo Abrucio (apud BRESSERPEREIRA; SPINK, 2006), não obedece ao puro modelo de decisão de compra vigente no mercado, pelo contrário, em casos em que os serviços públicos têm caráter compulsório, a escolha é inviável, como, por exemplo, os hospitais e serviços policiais.

Conforme Abrucio (apud BRESSER-PEREIRA; SPINK, 2006), o consumerism não contemplou de forma adequada um dos valores fundamentais da administração pública, a equidade. Isso confirma o óbvio, pois a iniciativa privada nunca visou à equidade, de modo que, ao adotar a competição entre os equipamentos públicos, o princípio da equidade desapareceu. A avaliação dos consumidores/clientes como fator principal para a obtenção do avanço profissional e para manter o emprego deu origem a grupos organizados de servidores públicos para atuarem em defesa de seus interesses, e fizeram de tudo, inclusive atos discricionários, para atender ao grupo organizado de consumidores/clientes com a intenção de que também se beneficiassem.

Outra disfunção consistiu na possibilidade de os consumidores/clientes passarem a se organizar em grupos de interesse, sobretudo em período de escassez de recursos públicos, o que os tornou empoderados e mais "consumidores" do que os outros, além de se beneficiarem de 
mais recursos, passando a serem tratados como "clientes preferenciais do serviço público", evidenciando que "[...] quando os recursos são limitados, o problema não é satisfazer os consumidores, mas que consumidores satisfazer." (ABRUCIO apud BRESSER-PEREIRA; SPINK, 2006, p. 188). Portanto, a adoção da competição entre os equipamentos sociais beneficiou somente o equipamento melhor avaliado, com maiores repasses de recursos, elevando a qualidade do serviço ofertado, porém, o equipamento mal avaliado recebia menos recursos, acarretando em desmotivação dos funcionários e em péssimo serviço prestado, desrespeitando um dos valores fundamentais da administração pública, a equidade.

Em síntese, o consumerism obteve avanços como a descentralização e a adoção de um novo modelo contratual, porém, ao propiciar a competição dos equipamentos, gerou equipamentos de ótima qualidade e de péssima qualidade, resultados extremos que se distanciaram do valor de equidade. Sendo assim, para corrigir essa disfunção e inserir outros valores no modelo gerencial de se administrar o Estado, surgiu o desenvolvimento do Public Service Orientation (PSO).

\subsubsection{Public Service Orientation (PSO)}

O Public Service Orientation (PSO), pode-se dizer, está em fase de amadurecimento, pois surge com a orientação de conceitos inovadores. É importante ressaltar que o PSO não propõe a volta do modelo burocrático weberiano, mas, sim, procura encontrar novas práticas para o modelo gerencial, explorando suas potencialidades e preenchendo suas lacunas. Sua reflexão levanta temas de caráter republicano, utilizando-se "[...] de conceitos como accountability, transparência, participação política, equidade e justiça, questões praticamente ausentes no debate do modelo gerencial." (ABRUCIO apud BRESSER-PEREIRA; SPINK, 2006, p. 190).

O modelo gerencial PSO foi desenvolvido sobre a base da descentralização, com o conceito da esfera pública. O PSO rebateu os argumentos dos ingleses conservadores ao resgatar ideais como participação política e transparência, e apresentou instrumentos para combater novas formas de clientelismo e corporativismo.

Os teóricos da PSO resgatam os ideais de participação política segundo um conceito mais amplo, o de esfera pública, que se utiliza da transparência como proteção contra novas formas particularistas de intervenção na arena estatal, como o são o clientelismo e o corporativismo. (ABRUCIO apud BRESSERPEREIRA; SPINK, 2006, p. 191). 
Sendo assim, a esfera pública é a estrutura dos conceitos do atual modelo gerencial, pois é entendida como um local de aprendizagem e em que deve ser desenvolvido o debate público para que os cidadãos aprimorem o aprendizado. Com base nessa ideia, o PSO ressaltou a importância de estar presente na atuação burocrática, principalmente na formulação de políticas públicas. A título de exemplificação, o planejamento estratégico deverá ser feito de forma transparente e participativa, saindo do confinamento da burocracia para ser discutido e revelado num processo de debate público (POLLITT, 1990, p. 150).

Segundo Abrucio (apud BRESSER-PEREIRA; SPINK, 2006, p. 190), a forma de competição entre os equipamentos públicos também foi repensada, bem como foi desenvolvido o conceito de cooperação para obter melhor oferta do serviço público, garantindo o princípio da equidade como um dos valores da PSO. Portanto, o modelo gerencial PSO defende virtudes políticas como a descentralização, o accountability, a transparência, a participação política, a equidade e a justiça, diferentemente do gerencialismo puro, que visava a descentralização como meio de tornar mais eficazes as políticas públicas, e do consumerism, que priorizou que os consumidores/clientes escolhessem os equipamentos com melhor qualidade.

O PSO também mudou o conceito ao tratar os usuários dos equipamentos sociais como cidadãos. A noção do termo cidadão remete à conotação coletiva, ao cidadão com direitos e deveres, distintamente do termo consumidor, que sempre esteve vinculado à tradição liberal, ao individual e ao privado.

O ponto que distingue a PSO das outras correntes é o conceito de cidadão, pois, enquanto o conceito de cidadão tem conotação coletiva - pensar na cidadania como um conjunto de cidadãos com direitos e deveres -, o termo consumidor (ou cliente) tem um referencial individual, vinculado à tradição liberal, a mesma que dá, na maioria das vezes, maior importância à proteção dos direitos do indivíduo do que à participação política, ou então maior valor ao mercado do que à esfera pública. (POLLITT, 1990, p. 129).

Em suma, a PSO tem como um de seus conceitos a "conjugação entre a accountability e o binômio justiça/equidade" (ABRUCIO apud BRESSER-PEREIRA; SPINK, 2006, p. 191), assim como a importância do processo de aprendizado social na esfera pública para criar uma nova cultura cívica, a cultura republicana descrita por Bresser-Pereira, para congregar políticos, funcionários e cidadãos.

A reforma da administração pública, atualmente, é um dos principais temas e de fundamental importância para a reforma do Estado. Dessa maneira, Bresser-Pereira (1998) propõe a construção do Estado republicano e seus conceitos serão essenciais para reformar a 
administração do Estado. Sem embargo, é fundamental aprimorar instrumentos para adoção e desenvolvimento do PSO de acordo com as características da realidade de cada sociedade, visando consolidar a transparência, a participação política e o controle social. Mas a questão mais relevante é se a adoção de práticas gerenciais através da desregulamentação e regulamentação da administração pública será eficiente para suprimir as disfunções burocrática weberianas. No capítulo quatro, será demonstrado como se encontra o atual cenário e se a saída será o modelo gerencial.

\subsection{Considerações parciais}

Procurou-se demonstrar, de forma panorâmica, como se desenvolveram, ao longo da história, as teses referentes às formas de governo. E quando as formas de governo se mesclam, tem-se a criação do governo misto. Destacou-se a teoria do governo misto, pois os governos não atuam através de categorias ideais, mas através de enredamentos. Porém, tendo em vista que o poder soberano consiste eminentemente na capacidade de fazer leis, a classe que detiver esse poder definirá a forma de governo. Acentuando-se quando esse poder pertencer ao senado, então o Estado será aristocrático; se pertencer ao rei, ele será monárquico; e se pertencer ao povo, ele será democrático.

Na administração pública, não é diferente, pois as formas de administrar adotadas também interagem entre si, criando modelos de administração mistos, enredados ${ }^{18}$. Contextualizamos a ditadura, pois, no Brasil, as duas primeiras reformas administrativas ocorreram em regimes autoritários, sendo adotados de cima para baixo, isentas da participação social. As formas de governo que eram definidas como boas/más e baseadas numa divisão tripartite (monarquia, aristocracia e democracia), depois foram alteradas para a divisão bipartite, e por fim, houve a negação do Estado defendido por Marx e Engels e a inserção da ditadura como uma forma de governo.

A transição das formas de organização do Estado, governo e administração caracterizase pelas reformas do Estado, ou seja, é necessário desregulamentar as instituições ineficientes para regulamentar novas instituições, adotando um novo desenho para o Estado brasileiro. É necessário, ainda, a reforma da gestão pública para atribuir aos funcionários públicos graduados maior poder discricionário, dependendo da existência de mecanismos efetivos de controle social para torná-los razoavelmente responsáveis.

\footnotetext{
${ }^{18}$ Ver item 3.4.
} 
Quando se pensa em transições das formas históricas de organização do Estado, devese ter a clareza de que se trata de um processo complexo, tanto histórico como intelectual, pois são necessárias a criação e a alteração de instituições. Atualmente, o Estado democrático de direito é considerado a melhor forma de Estado. Bresser-Pereira propõe o Estado republicano democrático.

O Estado republicano descrito por Bresser-Pereira (1998) possui governo democrático e sua administração é gerencial. A democracia, ao consolidar características como participativa ou deliberativa, passou a ser vista como moderna. A democracia moderna ficou conhecida como liberal quando focou nos interesses de grupos elitistas; foi social quando passou a atender os interesses sociais, a garantir os direitos sociais; por fim, é considerada participativa (republicana) ao consolidar o direito da participação popular e o controle social.

Percebe-se que Bresser-Pereira (1998) apresentou uma análise linear da democracia moderna, desenvolvendo as imperfeições da democracia liberal para as perfeições da democracia república. Mas desconsiderou que também ocorrem processos de regressão democrática. Morin (2000) afirma que é preciso afastar o indivíduo das decisões políticas, argumentando que eles não têm competências para questões mais complexas, que devem ser decididas pelos tecnocratas. O movimento de regressão dos princípios democráticos também ocorre ao atrofiar competências, ameaçar a diversidade e degradar o civismo. Assim, nota-se a fragmentação em diversos campos e a possibilidade de concebê-los juntos diminui ou desaparece.

Portanto, foi essencial apresentar as categorias "ideais" das formas de administrar o Estado para que, em seguida, se possa demonstrar como elas foram inseridas na administração do Estado brasileiro, através da ótica das reformas, adotando os modelos de administração pública de acordo com sua época vigente. 


\section{A ADMINISTRAÇÃO PÚBLICA FEDERAL}

A partir dos anos de 1980, a administração pública se destacou como um pilar fundamental para a reforma do Estado, tão fundamental que acabou sendo interpretada como a própria reforma do Estado. No Brasil, isso ocorreu devido ao cenário atuante de práticas patrimonialistas, focando praticamente todo o projeto em gestão de pessoal. Portanto, faz-se necessário descrever em que o DL 200/1967, CF88 e a EC 19/1998 avançaram e o quão próximo ficaram do modelo ideal teorizado de administrar o Estado, bem como demonstrar a interação entre eles.

O enfrentamento da crise da administração pública burocrática que começou no regime militar, com a reforma de 1967, não foi capaz de superar as práticas patrimonialistas, pois, segundo Bresser-Pereira e Spink (2006, p. 239), na época, o governo autoritário militar optou por não profissionalizar a burocracia no país, com os princípios básicos da redefinição das carreiras e de abertura de concursos públicos para a alta administração ${ }^{19}$, preferindo o caminho mais curto do recrutamento de administradores por intermédio de suas empresas estatais. Nessa conjuntura, a estratégia adotada pelo regime militar inviabilizou o avanço para uma burocracia forte conforme foi idealizada pela Reforma de Vargas. A Constituição de 1988 consolidou o enrijecimento burocrático e a persistência do patrimonialismo ${ }^{20}$, deixando a administração pública brasileira com alto custo e baixa qualidade.

A administração burocrática não conseguia corresponder às demandas do Estado social e econômico do século XX de forma ágil, com qualidade e com custo baixo para os serviços exigidos pelos cidadãos, caracterizando-se por ser “[ [...] lenta, cara, autorreferida, pouco ou nada orientada para o atendimento das demandas dos cidadãos" (BRESSER-PEREIRA; SPINK, 2006, p. 241).

A influência do setor privado (administração empresarial) sobre a administração pública trouxe conceitos como a descentralização e a flexibilização, que passaram a ser adotados pelos governos. Essas práticas se intensificaram a partir dos anos 70, com o cenário da crise do Estado e também da burocracia, ganhando forma nos anos de 1980 nos países centrais que caminharam em direção à administração pública gerencial.

No Brasil, em síntese, a administração gerencial começa a dar sinais em 1938, conforme Bresser-Pereira e Spink (2006), com a criação da primeira autarquia e se consolidando na

\footnotetext{
${ }^{19}$ Bresser-Pereira classifica a tecnocracia como a carreira de alto administradores.

${ }^{20}$ A transição democrática gerou insegurança nos servidores da alta carreira, assim adotou o regime de previdência integral e a transformação de funcionários celetistas para regimes estatutários.
} 
reforma de 1967, com a adoção da descentralização, isto é, da administração indireta. A criação do Ministério da Desburocratização em 1979, sob o comando de Hélio Beltrão, com o advento do Programa Nacional de Desburocratização, visou desenvolver uma administração pública com o princípio de retirar os usuários da condição colonial de súditos e trata-los como cidadãos.

Para Bresser-Pereira e Spink (2006, p. 247), o DL 200/1967 apresentou duas consequências inesperadas e indesejáveis. Ao permitir a contratação de empregados sem concurso público, fomentou a sobrevivência de práticas patrimonialistas. E por não se preocupar com as alterações na administração direta, deixou de desenvolver carreiras de altos administradores, o que acarretou no enfraquecimento do núcleo estratégico, o que se mostrou uma manobra oportunista do regime militar, que preferiu contratar os quadros superiores das empresas estatais.

A Constituição de 1988 contrariou o "espírito burocrático-legal”, permitindo que alguns privilégios fossem consolidados ou criados. Assim, o estabelecimento de um sistema de aposentadoria com remuneração integral sem critérios e a possibilidade de mais de 400 mil funcionários celetistas de fundações e autarquias se transformarem em funcionários estatutários fizeram aumentar excessivamente as despesas e caracterizou essas ações como "[...] um tributo pago ao patrimonialismo ainda presente na sociedade brasileira e uma consequência do corporativismo que recrudesceu com a abertura democrática" (BRESSER-PEREIRA; SPINK, 2006, p. 247). Nesse aspecto, a Constituição de 1988 apresentou alguns desvios, mas, ao ser analisada como um todo, demonstrou mais avanços, como, por exemplo, no controle social e na participação.

A estabilidade dos servidores, que gerou a criação de regimes estatutários, foi instituída como uma medida para evitar as práticas patrimonialistas dominantes nos regimes précapitalistas, isto é, quando se alterava o governo, todos os funcionários eram demitidos, acarretando na descontinuidade das políticas públicas. Essa situação, de acordo com Costin (2010), levou à definição do comportamento do servidor com base em regulamentos exaustivos, enfatizando a impessoalidade, tanto no acesso ao serviço público como na progressão de carreira, o que fez do conhecimento das regras um recurso de poder (dominação racional-legal com administração burocrática). Também consolidando os princípios da administração burocrática como:

- formalismo - atividades, estruturas e procedimentos estão codificados em regras exaustivas para evitar a imprevisibilidade e instituir maior segurança jurídica nas decisões administrativas; 
- impessoalidade - interessa o cargo e a norma, e não a pessoa em sua subjetividade. Por isso, carreiras bem estruturadas em que a evolução do funcionário possa ser prevista em bases objetivas são próprias desta forma de administração;

- hierarquização - a burocracia contém uma cadeia de comando longa e clara, em que as decisões obedecem a uma lógica de hierarquia administrativa, prescrita em regulamentos expressos, com reduzida autonomia do administrador;

- rígido controle de meios - para se evitar a imprevisibilidade e introduzir ações corretivas a tempo, um constante monitoramento dos meios, especialmente dos procedimentos adotados pelos membros da administração no cotidiano de suas atividades. (COSTIN, 2010, p. 32).

A rigidez e a centralização que caracterizou a administração burocrática frearam o desenvolvimento do capitalismo moderno. No Brasil, segundo Bresser-Pereira e Spink (2006, p. 265), para se obter resultados eficazes na adoção do modelo gerencial na administração pública brasileira, foram adotadas três dimensões:

1) a institucional-legal, por meio da qual se modificam as leis e se criam ou modificam instituições; 2) a cultural, baseada na mudança dos valores burocráticos para os gerenciais; e 3) a da cogestão.

As exigências do neoliberalismo e as pressões da sociedade geraram novas tarefas atribuídas ao Estado Social, como a prestação de diversos serviços públicos (saúde, educação, meio ambiente, combate às desigualdades), e tornaram indispensável a ideia da eficiência da máquina pública, visando a uma administração menos hierárquica, mais flexível e a melhoria da qualidade dos serviços prestados ao cidadão. Conforme Costin (2010, p. 33), outros fatores reforçaram a necessidade de um novo modelo de administrar o Estado, sendo eles,

[...] a crise das finanças públicas devido a déficits acumulados e a mudanças demográficas em curso; a preocupações crescentes da sociedade com ética, transparência e imputabilidade dos dirigentes e políticos; a pressões por maior competitividade devido à globalização; as possibilidades abertas com a tecnologia da informação; o fortalecimento de uma visão liberal de governança pública.

Esses fatores levaram ao surgimento, definido por Bresser-Pereira e Spink (2006), da chamada administração gerencial ou Nova Gestão Pública. O modelo gerencial, além das medidas de contenção fiscal, também teve em vista o "[...] fortalecimento do gerenciamento público, de instituições de controle e imputação de resultados e estruturas mais flexíveis em que o cidadão pode se perceber e ter voz, como usuário de serviços públicos e contribuinte." (COSTIN, 2010, p. 33). 
Em resumo, o cenário desenvolvido pelo capitalismo e a mudança de paradigma do Estado, conduzido pela globalização, deixou de proteger as respectivas economias da competição internacional e passou a exercer o papel de facilitador para que a economia nacional se tornasse internacionalmente competitiva. Assim, categorizou como a crise dos Estados nos anos de 1990 para implicar na necessidade de reformá-los e reconstruí-los. Nesse contexto, acentuou-se o movimento neoliberal que influenciou a reforma administrativa do Estado. Contudo, para Bresser-Pereira e Spink (2006, p. 237), houve duas propostas de reforma, a neoliberal e a social-democrática, cuja diferença é que o

[...] objetivo da primeira é retirar o estado da economia, enquanto o da segunda é aumentar a governança do Estado, é dar meios financeiros e administrativos para que ele possa intervir efetivamente, sempre que o mercado não tiver condições de coordenar adequadamente a economia.

Na tentativa de agregar os agentes políticos no governo FHC, o então ministro da MARE propôs um conceito novo para superar as divergências em relação às propostas apresentadas pelo Plano Diretor da Reforma do Aparelho do Estado e desenvolveu uma proposta socialliberal, ou seja, um Estado republicano como base na administração gerencial.

O aparelho do Estado é

[...] a administração pública em sentido amplo, ou seja, a estrutura organizacional do Estado, em seus três poderes (Executivo, Legislativo e Judiciário) e três níveis (União, Estados-membros e Municípios). O aparelho do Estado é constituído pelo governo, isto é, pela cúpula dirigente nos Três Poderes, por um corpo de funcionários, e pela força militar. O Estado, por sua vez, é mais abrangente que o aparelho, porque compreende adicionalmente o sistema constitucional-legal, que regula a população nos limites de um território. O Estado é a organização burocrática que tem o monopólio da violência legal, é o aparelho que tem o poder de legislar e tributar a população de um determinado território. (MARE, 1995, p. 12).

A partir dessa definição de aparelho do Estado, mais especificamente em sua estrutura organizacional, foram aprovadas as normas para legitimar as reformas administrativas apresentadas pelo Poder Executivo. Geralmente, em períodos de crise do Estado, uma das saídas é reformar seu aparelho.

Outro fator que influenciou na desregulamentação e regulamentação na administração pública foi o seu movimento pendular. De acordo com Pimenta (1994), durante o período republicano, a institucionalização da função-administração no governo federal foi cíclica, ou seja, nas décadas de 30 a 50, viveu-se um processo de centralização organizacional no setor 
público. Já nas décadas de 60 a 80, ocorreu a descentralização, através da expansão da administração indireta e da contratação de funcionários celetistas. Porém, a Constituição de 1988 centralizou novamente ao instituir o regime jurídico único para os servidores públicos. Pimenta (1994) descreve o movimento pendular da administração pública federal, sendo que o mesmo ocorreu com o Estado brasileiro, hora neoliberal, hora social-democrático.

Portanto, pretendemos demonstrar, a partir das legislações brasileira que versam sobre as reformas administrativas, em especial, o DL 200/1997 e a EC 19/1998, descrevendo-as por meio das categorias dos modelos ideais de administração do Estado, as diversidades e interação em sua implantação na dimensão racional-legal. A mudança mais significativa ocorreu no âmbito da administração de pessoal, pois a mentalidade patrimonialista (confusão do público com o privado) refletiu diretamente nos gastos de pessoal.

\subsection{Modelo patrimonialista brasileiro}

Para facilitar o entendimento do processo de transformação das formas de administrar o Estado brasileiro, será abordado a comparação dos tipos ideias de administração pública com a sua adoção na administração pública federal. O movimento pela reforma administrativa nos países em desenvolvimento se acentuou devido ao cenário precário em que suas administrações se encontravam e às pressões do neoliberalismo para atender com eficiência a suas demandas.

Em cada país, apresentou-se uma forma peculiar de administrar o Estado e, no Brasil, ocorreu algo semelhante. As peculiaridades da cultura brasileira desenvolveram uma administração pública esquizofrênica (tomadas de decisões irreais) e letárgica (desanimada) em sua praticidade. Através da desregulamentação e regulamentação, faremos uma comparação entre o modelo patrimonialista brasileiro e o modelo patrimonialista categorizado por Weber (2014), e assim respectivamente com os demais modelos.

O modelo patrimonialista caracterizado por Weber (2014), ao defender a administração burocrática, era a forma de administrar o Estado absoluto e visava manter uma aristocracia dependente da corte. Sua finalidade era cuidar da guerra, cobrar impostos e administrar a justiça. Além de manter a aristocracia, também permeou o nepotismo e a indiferença entre o patrimônio público e o patrimônio privado.

Em síntese, Weber (2014) destaca as práticas de administrar o Estado no período précapitalista como patrimoniais. Para facilitar a compreensão, o quadro 4 estabelece uma analogia entre o modelo patrimonialista e o modelo patrimonialista brasileiro. 
Quadro 4 - Comparação do modelo patrimonialista

\begin{tabular}{|c|c|}
\hline Modelo Patrimonialista & Modelo Patrimonialista no Brasil \\
\hline $\begin{array}{l}\text { Ausência de "competência" fixa segundo regras } \\
\text { objetivas; } \\
\text { Ausência de hierarquia racional fixa; } \\
\text { Ausência de nomeação regulada por contrato livre e o } \\
\text { ascenso regulado; } \\
\text { Ausência de formação profissional (como norma), } \\
\text { (Muitas vezes) o salário fixo e (ainda mais } \\
\text { frequentemente) o salário pago em dinheiro; } \\
\text { Impõe resistência à existência de estatutos formalmente } \\
\text { racionais e com duração confiável; } \\
\text { Não há quadro de funcionários com qualificação; } \\
\text { A arbitrariedade material e a vontade puramente pessoal } \\
\text { do senhor e do quadro administrativo, esfera em que } \\
\text { eventual corrupção, que nada mais é do que a } \\
\text { degeneração do direito as taxas não regulamentadas, teria } \\
\text { importância relativamente mínima, por ser praticamente } \\
\text { calculável, se apresentasse uma magnitude constante e } \\
\text { não um fator viável para cada funcionário. Em caso de } \\
\text { arrendamento de cargos, o funcionário, para obter lucro } \\
\text { de seu capital investido, vê-se imediatamente obrigado a } \\
\text { aplicar meios de extorsão. }\end{array}$ & $\begin{array}{l}\text { No período colonial, não havia } \\
\text { competências e hierarquias claramente } \\
\text { reguladas por leis; } \\
\text { Excessivos cargos e ausência de plano de } \\
\text { carreira; } \\
\text { Não havia preocupação em formar } \\
\text { quadros profissionais para a administração } \\
\text { pública; o interesse era manter os acordos } \\
\text { políticos em troca de cargos; } \\
\text { Como não havia controle das despesas } \\
\text { nem a separação entre público e o privado, } \\
\text { ocorriam pagamentos em dinheiro de } \\
\text { forma direta, conhecidos como } \\
\text { "pagamento por fora"; } \\
\text { Ausência de estatutos, regulado art. 156 da } \\
\text { Constituição Federal de 1939; } \\
\text { Ausência de quadros qualificados para } \\
\text { exercer as atividades do Estado; } \\
\text { Ausência de regulação de taxas, corrupção } \\
\text { e extorsão. }\end{array}$ \\
\hline
\end{tabular}

Fonte: Elaboração própria.

Como é possível observar, a administração pública federal está totalmente inserida na descrição patrimonialista de Weber (2014). A base cultural brasileira está solidificada em ações patrimonialistas, convivendo com a apropriação do interesse privado pelo grupo dominante sobre os interesses públicos através do Estado, mantendo-se os cargos vitalícios, as posições privilegiadas, as taxas extraordinárias, os subornos, os presentes e, principalmente, a prática do clientelismo. Também pode-se notar práticas como a ausência de formação profissional, a resistência ao novo (mudanças de normas) e a corrupção (desvios do dinheiro público, extorsão e utilização da função para interesses próprios).

Atualmente, essas práticas ainda persistem na administração pública brasileira em todas as esferas (federal, estadual e municipal). Tendo em vista que essas ações são de interesse de um grupo dominante, fica claro que o período colonial foi marcado pela desregulação da administração do Estado brasileiro. É importante frisar que a regulação burocrática marcada pelo governo Vargas e, posteriormente, no DL 200/67, não foram suficientes para suprimir essas práticas, que ainda persistem tanto nos cargos eletivos, como nas atitudes dos servidores de carreira.

\subsection{Modelo "ideal” burocrático e o modelo burocrático brasileiro}


O desenvolvimento do capitalismo industrial e a ascensão do liberalismo exigiram dos Estados a necessidade de deixar claro a distinção entre o Estado e o mercado, entre o público e o privado, organização e centralização. Nesse contexto, Weber (2014) propõe o modelo "ideal" burocrático. Em tese, no Brasil, umas das práticas mais comuns no patrimonialismo, o clientelismo, deixou de ser estratégia de uma política central, mas ainda segue como uma atuação essencial para manter a governabilidade. Tal prática também viabilizou politicamente a adoção de concursos na admissão de funcionários e de um serviço público autônomo baseado no mérito.

O modelo ideal burocrático atingirá sua plenitude quando os quadros administrativos atingirem as práticas consideradas ideais, como já foi demonstrado no capítulo dois. O quadro 5 descreverá as práticas burocráticas definidas por Weber (2014), apresentando o aperfeiçoamento e a superioridade em relação às práticas patrimonialistas. Assim, a burocracia focou a precisão, a rapidez, a univocidade, o conhecimento da documentação, a continuidade, a discrição, a uniformidade, a subordinação rigorosa, a diminuição de atritos e custos materiais e pessoais, para racionalizar a administração do Estado e suprimir as práticas da administração patrimonialista.

Quadro 5 - Comparação do modelo burocrático

\begin{tabular}{|c|c|}
\hline Modelo Ideal Burocrático & Modelo Burocrático Brasileiro \\
\hline $\begin{array}{l}\text { São pessoalmente livres; } \\
\text { Obedecem somente às obrigações objetivas do } \\
\text { seu cargo; } \\
\text { Competências funcionais fixas; } \\
\text { São nomeados (e não eleitos) numa hierarquia } \\
\text { rigorosa de cargos; } \\
\text { Exercem seu cargo como profissão única ou } \\
\text { principal; } \\
\text { Têm a perspectiva de uma carreira: } \\
\text { "progressão" por tempo de serviço ou } \\
\text { eficiência, ou ambas as coisas, dependendo do } \\
\text { critério dos superiores; } \\
\text { Em virtude de um contrato, portanto, (em } \\
\text { princípio) sobre a base de livre seleção, segundo } \\
\text { a qualificação profissional - no caso mais } \\
\text { racional: qualificação verificada mediante a } \\
\text { prova e certificada por diploma; } \\
\text { Trabalham em "separação absoluta dos meios } \\
\text { administrativos" e sem apropriação do cargo; } \\
\text { Estão submetidos a um sistema rigoroso e } \\
\text { homogêneo de disciplina e controle do serviço. }\end{array}$ & $\begin{array}{l}\text { Criação do Departamento Administrativo do Serviço } \\
\text { Público (Dasp) (Decreto-Lei no } 579 \text {, de } 30 \text { de julho de } \\
\text { 1938); } \\
\text { As competências funcionais, remunerações e } \\
\text { hierarquia foram estabelecidas no Decreto-Lei no } 200 \\
\text { de } 1967 \text { e fixados pela Lei no } 3780 \text {, de } 12 \text { de julho de } \\
1960 \text { - Dispõe sobre a Classificação de Cargos do } \\
\text { Serviço Civil do Poder Executivo, estabelece os } \\
\text { vencimentos correspondentes e pela Lei no } 5645 \text { de } 10 \\
\text { de dezembro de } 1970 \text { (Estabelece diretrizes para a } \\
\text { classificação de cargos do Serviço Civil da União e } \\
\text { das autarquias federais); } \\
\text { Os planos de carreira se intensificam nos anos } 90 \text { e } \\
\text { com a Constitucional no } 19 \text { de } 1998 \text {; } \\
\text { Adoção de concursos públicos; } \\
\text { Responsabilização fixada no Decreto-lei no } 200 \text { de } \\
\text { 1967, em especial no Título XI; } \\
\text { Regulados pelo Decreto-lei no } 200 \text { de } 25 \text { de fevereiro } \\
\text { de } 1967 \text {, especificamente nos títulos II, III e IV. }\end{array}$ \\
\hline
\end{tabular}

Fonte: Elaboração própria. 
A burocracia weberiana permitiu o caráter racional-legal (regulação) de administrar o Estado, baseado na regra, na finalidade, nos meios, na impessoalidade "objetiva" que dominam suas atitudes, caracterizando o avanço do racionalismo e a superação das formas estruturais irracionais, além de facilitar o desenvolvimento do liberalismo nos países em desenvolvimento. No Brasil, podemos descrever a regulação burocrática entre 1930 e 1967, em específico, pelo DL 200/1967. Assim, a administração pública federal sob a vigência de regimes autoritários adotou práticas gradualmente burocráticas, o que, futuramente, refletiria na EC 19/1998.

É importante ressaltar que o contexto brasileiro era perversamente dominado pelas práticas patrimonialistas, predominantemente culturais, por isso, o modelo burocrático apresentou resistências e foi adotado de forma gradual. As práticas como a intuição de competências fixas, a obediência às obrigações objetivas do seu cargo, a hierarquia rigorosa de cargos, a profissão de servidor como única ou principal, a perspectiva de carreira, a qualificação verificada mediante prova e certificada por diploma e a submissão a um sistema rigoroso e homogêneo de disciplina e controle do serviço foram práticas instituídas desde a reforma de Vargas em 1930 até o DL 200/1967. Essas práticas enfatizavam a necessidade de superar o enraizamento nas práticas patrimoniais herdadas do período colonial.

Vale salientar que, no que tange às finanças públicas, o DL 200/1967 criou dois mecanismos, o orçamento-programa e a programação financeira. O orçamento-programa, segundo Costin (2010, p. 59), será elaborado a cada ano, detalhando cada etapa do programa plurianual a ser realizado no exercício seguinte. Essa prática tem como objetivo ajustar o ritmo de execução do orçamento-programa ao fluxo provável de recursos. Desse modo, concomitantemente à elaboração da programação financeira de desembolso, irá assegurar a liberação oportuna dos recursos necessários à execução dos programas anuais de trabalho. Passados cinquenta anos do decreto-lei, essa prática ainda encontra dificuldades, principalmente nos municípios ${ }^{21}$, para serem executadas. A ineficiência dessa norma em sua execução ocorre devido à desorganização financeira dos municípios, o que acarreta gastos desnecessários para a administração pública e a ausência de planejamento e controle das finanças públicas.

No entanto, para Costin (2010, p. 52), a mudança mais impactante foi na administração de pessoal. Como iremos analisar as leis no contexto operacional da administração pública, a administração de pessoal terá um foco maior. No período Vargas, houve, na Constituição de

\footnotetext{
${ }^{21}$ O decreto-lei n 200 de 1967 trata apenas da administração pública federal, não citando os estados e municípios, porém, como esses entes não tem regulação sobre o orçamento, utilizam-se do decreto-lei.
} 
1934, a adoção do concurso público, a classificação de cargos, a fixação de salários, a institucionalização de treinamento e o aperfeiçoamento dos funcionários públicos, a introdução de sistema de mérito, ações voltadas a dotar de racionalidade a máquina pública (impessoalidade e valorização do saber técnico). Em 1939, foi criado o estatuto do funcionário público. Essas medidas adotadas são as principais na Era Vargas e demonstram a similaridade às práticas burocráticas weberianas.

O DL 200/1967 associou a ideia de dar autonomia aos gestores, simultaneamente a um sistema de mérito da administração burocrática, e a possibilidade de contratar especialistas para atender às exigências de trabalho técnico, ocorrendo de forma similar com a administração gerencial (COSTIN, 2010).

Posteriormente, demonstraremos que, ainda hoje, há uma dificuldade em racionalizar a administração pública federal, o que pode ter levado o modelo gerencial, no primeiro momento, a melhorar algumas disfunções da administração burocrática herdada, além de avançar em conceitos modernos de administração pública. Contudo, na tentativa de superar essa perseverança patrimonialista, antes mesmo de aperfeiçoar algumas práticas burocráticas, houve um momento de rápida evolução do capitalismo e dos ideais neoliberais. Sendo assim, foram exigidas da administração pública brasileira medidas emergenciais, como a adoção de práticas gerenciais.

\subsection{O modelo "ideal" gerencial (PSO) e o modelo gerencial brasileiro}

O modelo gerencial de administrar o Estado surgiu com a crise fiscal do sistema capitalista e a necessidade de adotar políticas de redução de custos, afetando diretamente seu aparelho. As medidas tomadas, a princípio, foram a redução de gastos de pessoal (por isso, a reforma gerencial teve um peso maior sobre a administração de pessoal - redução de gastos) e o aumento da eficiência governamental.

A estrutura organizacional e o elevado custo de pessoal são problemas herdados desde o período colonial, consolidado por uma cultura de práticas patrimonialistas. Nesse contexto, os teóricos propuseram alterações na burocracia weberiana, que se apresentava como um modelo muito lento e excessivamente apegado às normas, isto é, ineficiente. Sendo assim, a burocracia weberiana foi definida como rígida, constituída de uma hierarquia forte e total separação entre o público e o privado. 
Nessa perspectiva é que se tem o desenvolvimento do modelo gerencial de administração pública, baseado nas ideias da iniciativa privada. Assim, o enfraquecimento do poder do Estado e os avanços de uma ideologia privatizante levaram o modelo burocrático à crise.

O modelo gerencial passou por três definições: inicialmente, ficou conhecido como gerencialismo puro e visou à eficiência. Em seguida, denominado consumerism, tratou os usuários como consumidores e focou na efetividade dos serviços públicos. Por fim, tem-se o terceiro modelo gerencial, o Public Service Orientation (PSO), que é um aprimoramento dos últimos modelos e se caracteriza por se referir aos usuários dos serviços públicos como cidadãos, focando também no accountability e na equidade. Para fazer a análise comparando com o modelo gerencial brasileiro, utilizaremos apenas o PSO.

Quadro 6 - Comparação do modelo gerencial

\begin{tabular}{|c|c|}
\hline $\begin{array}{c}\text { Modelo Ideal } \\
\text { Gerencial (PSO) }\end{array}$ & Modelo Gerencial Brasileiro \\
\hline Descentralização & $\begin{array}{l}\text { Art. } 4^{\circ} \text { do decreto-lei no } 200 \text { de } 25 \text { de fevereiro de 1967, define a administração } \\
\text { indireta. }\end{array}$ \\
\hline Accountability & $\begin{array}{l}\text { Art. } 12 \text { da Emenda Constitucional n }{ }^{\circ} 19 \text { de } 1998 \text {, prestação de contas sobre o } \\
\text { dinheiro, bens e valores públicos. }\end{array}$ \\
\hline Transparência & $\begin{array}{l}\text { Art. } 5^{\circ} \text { da Emenda Constitucional n }{ }^{\circ} 19 \text { de 1998, publicação dos subsídios e } \\
\text { remuneração dos cargos. }\end{array}$ \\
\hline Participação & $\begin{array}{l}\text { Art. } 3^{\circ} \text { da Emenda Constitucional } \mathrm{n}^{\circ} 19 \text { de } 1998 \text {, versa sobre a participação do } \\
\text { usuário (Regulamentado pela Lei } \mathrm{n}^{\circ} 13.460 \text { de } 26 \text { de junho de } 2017 \text { ) }\end{array}$ \\
\hline \multirow[t]{2}{*}{ Autonomia } & $\begin{array}{l}\text { Art. } 3^{\circ} \S 8^{\circ} \text { da Emenda Constitucional } \mathrm{n}^{\circ} 19 \text { de } 1998 \text {, cria o contrato de gestão do } \\
\text { serviço público, possibilitando maior autonomia gerencial, financeira e } \\
\text { orçamentária aos administradores, ampliando a autonomia dos órgãos públicos } \\
\text { mediante negociação entre administradores e poder público. }\end{array}$ \\
\hline & $\begin{array}{l}\text { Art. } 22 \text { da Emenda Constitucional }{ }^{\circ} 19 \text { de } 1998 \text {, permite que as empresas públicas } \\
\text { e as sociedades de economia mista tenham regulamento próprio para compras } \\
\text { governamentais. }\end{array}$ \\
\hline \multirow[t]{6}{*}{$\begin{array}{l}\text { Eficiência } \\
\text { Administrativa }\end{array}$} & $\begin{array}{l}\text { Art. } 3^{\circ} \text { inciso V da Emenda Constitucional } n^{\circ} 19 \text { de 1998, reserva percentual de } \\
\text { cargos em comissão para servidores de carreira. }\end{array}$ \\
\hline & $\begin{array}{l}\text { Art. } 6^{\circ} \text { da Emenda Constitucional } n^{\circ} 19 \text { de } 1998 \text {, flexibilização da estabilidade do } \\
\text { servidor público e a insuficiência de desempenho passa a ser passível de punição } \\
\text { com a perda do cargo (Projeto de Lei do Senado }{ }^{\circ} 116 \text {, de } 2017 \text { ) }\end{array}$ \\
\hline & $\begin{array}{l}\text { Art. } 5^{\circ} \S 7^{\circ} \text { da Emenda Constitucional } n^{\circ} 19 \text { de } 1998 \text {, a economia com despesas } \\
\text { correntes do órgão poderá ser revertida, inclusive sob forma de prêmio ou } \\
\text { adicional, para seus servidores. }\end{array}$ \\
\hline & $\begin{array}{l}\text { Art. } 5^{\circ} \text { da Emenda Constitucional no } 19 \text { de } 1998 \text {, a lei de iniciativa dos presidentes } \\
\text { da República, do STF, da Câmara e do Senado fixará o subsidio dos ministros do } \\
\text { STF. }\end{array}$ \\
\hline & $\begin{array}{l}\text { Art. } 5^{\circ} \text { da Emenda Constitucional } \mathrm{n}^{\circ} 19 \text { de } 1998 \text {, determina que o membro de poder } \\
\text { ou detentor de mandato eletivo seja remunerado apenas por um subsidio único. }\end{array}$ \\
\hline & $\begin{array}{l}\text { Art. } 5^{\circ} \$ 2^{\circ} \text { da Emenda Constitucional n }{ }^{\circ} 19 \text { de } 1998 \text {, exige a criação das escolas de } \\
\text { governos. }\end{array}$ \\
\hline
\end{tabular}




\begin{tabular}{|c|c|}
\hline & $\begin{array}{l}\text { Art. } 32 \text { da Emenda Constitucional } \text { n }^{\circ} 19 \text { de } 1998 \text {, estabelece critérios diferenciados } \\
\text { de remuneração, admissão e demissão de servidores que desenvolvam atividades } \\
\text { exclusivas de Estado. }\end{array}$ \\
\hline & $\begin{array}{l}\text { Art. } 3^{\circ} \text { inciso } X \text { da Emenda Constitucional no } 19 \text { de } 1998 \text {, assegura a revisão geral } \\
\text { anual da remuneração. }\end{array}$ \\
\hline \multirow[t]{2}{*}{ Controle } & $\begin{array}{l}\text { Art. } 3^{\circ} \text { inciso XI da Emenda Constitucional } \mathrm{n}^{\circ} 19 \text { de } 1998 \text {, estabelece subsídios } \\
\text { dos ministros STF como referência para o teto máximo da remuneração dos } \\
\text { servidores de todos os poderes e de qualquer nível de governo. }\end{array}$ \\
\hline & $\begin{array}{l}\text { Art. } 5^{\circ} \S 2^{\circ} \text { da Emenda Constitucional } \mathrm{n}^{\circ} 19 \text { de } 1998 \text {, para incentivar o controle } \\
\text { social, os três poderes publicarão anualmente os valores do subsídio e da } \\
\text { remuneração de seus servidores. }\end{array}$ \\
\hline
\end{tabular}

Fonte: Elaboração própria.

O quadro 6 demonstra a introdução de conceitos gerenciais pela EC 19/1998 na administração pública federal, pois é necessário a regulamentação de alguns artigos, como por exemplo, a participação do usuário, sendo especificado através da lei federal no 13.460 de 26 de junho de 2017. Quanto regulamentação sobre a avaliação de desempenho dos servidores segue em tramitação através do projeto de lei no 116 de 2017.

Percebe-se nitidamente a ênfase da administração gerencial na gestão de pessoal, apresentando a maioria das práticas gerenciais na operacionalização do Estado, para melhorar a eficiência administrativa.

É importante destacar que o Public Service Orientation (PSO), pode-se dizer, está em fase de desenvolvimento e que alguns dos seus conceitos são inovadores, colocando em xeque antigos valores de um arcabouço teórico fechado, isto é, atualmente, práticas que foram categorizadas como "gerencias", a participação e a transparência, ainda carecerem de efetividade. Isso ocorre em razão dos conflitos de interesse do grupo dominante, que prefere resistir a transparência e o compartilhamento de decisões políticas de interesse coletivo com a sociedade.

Assim, conceitos como descentralização, accountability, transparência, participação, autonomia, eficiência e controle, entendidos pelos teóricos do gerencialismo como base essencial para o modelo, foram comparados a práticas adotadas na EC 19/1998. Em suma, as características mais relevantes da administração gerencial adotadas no Brasil foram:

- sistemas de gestão e controle centrados em resultados e não mais em procedimentos; - maior autonomia gerencial do administrador público; • avaliação (e divulgação) de efeitos/produtos e resultados tornam-se chaves para identificar políticas e serviços públicos efetivos; • estruturas de poder menos centralizadas e hierárquicas, permitindo maior rapidez e economia na prestação de serviços e a participação dos usuários; • contratualização de resultados a serem alcançados, com explicitação mais clara de aportes para 
sua realização; • incentivos ao desempenho superior, inclusive financeiros; • criação de novas figuras institucionais para realização de serviços que não configuram atividades exclusivas de Estado, como PPP (parcerias públicoprivadas) e Organizações Sociais e Oscips (Organizações da Sociedade Civil de Interesse Público) que podem estabelecer parcerias com o poder público. (COSTIN, 2010, p. 34).

Como se pode notar no quadro 6, ao utilizar as principais caraterísticas do PSO e comparar com a EC 19/1998, percebe-se que a emenda adotou práticas gerenciais para superar a resistência das práticas patrimonialistas e burocráticas. Esse cenário será melhor detalhado posteriormente, quando da exposição da interseção entre os modelos. Todavia, importa frisar que a descentralização se iniciou com o DL 200/1967, conhecido como a segunda reforma ${ }^{22}$ burocrática brasileira, que teve seus princípios alicerçados no modelo weberiano.

As duas práticas que enfatizaram a reforma do aparelho do Estado foram a eficiência administrativa e o controle. A EC 19/1998 legitimou algumas práticas burocráticas descritas por Weber (2014), destacando claramente a necessidade de criar novas normas (regulamentação) para superar a vigência das práticas patrimonialista e, consequentemente, desenvolver a burocracia para servir com eficiência o novo modelo que se implantava.

A consolidação da burocracia, ou seja, o aperfeiçoamento que ocorreu na reforma gerencial, como, por exemplo, a reserva percentual de cargos em comissão para servidores de carreira, afirmou a importância de ter funcionários qualificados para tomada de decisão e continuidade administrativa, reduzindo o número de cargos para alocação dos séquitos políticos sem qualificação. Ainda, a flexibilização da estabilidade do servidor público e a insuficiência de desempenho passaram a ser passíveis de punição, com a perda do cargo, práticas que também são burocráticas, pois estão condicionadas ao proposto por Weber (2014), visto que os servidores estarão submetidos a um sistema rigoroso e homogêneo de disciplina e controle do serviço.

A exigência de criação das escolas de governos que serão utilizadas para qualificar quadros da administração pública está condicionada à proposta weberiana para combater o patrimonialismo que se ausentou de quadros qualificados. O estabelecimento de critérios diferenciados de remuneração, admissão e demissão de servidores que desenvolvam atividades exclusivas de Estado também está relacionado à necessidade de Weber (2014) de se criar competências funcionais fixas.

O modelo gerencial não foi implantado de forma integral por conhecer “[...] dissonâncias

\footnotetext{
${ }^{22}$ Considera-se a primeira reforma administrativa as práticas burocráticas adotadas no período Vargas.
} 
nos discursos que justificavam sua implantação, disputas entre emergências fiscais e esforços por inovação.” (COSTIN, 2010, p. 34). Também, na convivência da administração burocrática com a administração patrimonialista, alguns grupos se preocuparam que a menor rigidez pudesse constituir uma porta aberta para o clientelismo.

A reforma gerencial avançou ao introduzir a eficiência entre os princípios da administração pública, a flexibilização da estabilidade, o fim do regime jurídico único ${ }^{23}$, a participação popular, os contratos de gestão, os tetos de remuneração e o estágio probatório.

- a introdução da eficiência entre os princípios que deveriam nortear a Administração Pública (antes incluíam apenas a legalidade, a impessoalidade, a moralidade e a publicidade); • a flexibilização da estabilidade, incluindo-se, como hipóteses para demissão de servidores, a insuficiência de desempenho e o excesso de quadros (com direito a indenização). No primeiro caso, trata-se de um instrumento de gestão, no segundo, uma maneira de poder reduzir a pressão sobre as finanças públicas, parcialmente regulamentada pela Lei de Responsabilidade Fiscal. A não definição pelo Congresso de carreiras de Estado (por pressões corporativistas e erros de condução do próprio executivo), que teriam proteções adicionais, em caso de configuração de situações de demissão, tornou inócuo esse dispositivo; - o fim do Regime Jurídico Único - o Estado não se viu obrigado a apenas contratar servidores estatutários. Esse dispositivo encontra-se pendente de decisão do Supremo, devido à Ação Direta de Inconstitucionalidade interposta pelo PT, PSB e PC do B em 2000. Mas uma liminar concedida em agosto de 2007 reinstituiu a redação original do artigo em que se introduzia a possibilidade de diferentes regimes jurídicos; • participação popular e proteção dos usuários de serviços públicos - dispositivo estabelece na Constituição a participação popular em decisões da Administração Pública e a elaboração de lei de defesa dos usuários de serviços públicos; • contratos de Gestão - instrumento importante para se estabelecer o controle por resultados, base da Administração Gerencial. A Constituição estabeleceu que uma lei deveria ampliar a autonomia gerencial, orçamentária e financeira dos órgãos da Administração Pública, mediante contrato "que tenha por objeto a fixação de metas de desempenho"; • tetos de remuneração - limite máximo à remuneração de servidores, já incluído na Constituição de 1988, mas imperfeições de redação permitiram ao STF excluir do dispositivo vantagens pessoais. Nova redação foi dada para evitar o problema; - estágio probatório - o servidor só se tornará efetivo depois de três anos (antes o estágio probatório era de dois, mas a efetivação era quase automática). (COSTIN, 2010, p. 69).

A EC 19/1998, conhecida por inserir o gerencialismo na administração pública brasileira, precisou regulamentar práticas burocráticas para poder avançar na adoção de suas práticas. Tem-se, nesse contexto, a confirmação de que a burocracia não atingiu sua plenitude na administração pública federal, iniciada em 1930 na era Vargas e no DL 200/67. É evidente que, ao aperfeiçoar o modelo burocrático, demonstrou-se como o patrimonialismo ainda persiste na

23 A ADIN n 2.135 declarou inconstitucional a redação dada pela EC nº 19/98 ao caput do art. 39 da CF. 
administração, tornando-se um desafio a ser enfrentado em todas as esferas do aparelho estatal brasileiro.

A separação entre os modelos de administrar o Estado descritos pelos teóricos e comparados um a um com as leis que o regularam no Brasil, foi feita para facilitar a compreensão da descrição. As reformas na administração pública brasileira transitaram entre os modelos burocrático e gerencial, ambos tendo como desafio tornar a administração pública racional-legal e, assim, superar o enraizamento das práticas patrimonialistas.

Para Torres (2017), a reforma do aparelho do Estado do governo FHC se deu por meio do discurso sobre a crítica ao excesso de burocracia, para pautar ideologicamente as "[...] privatizações e o deslocamento dos centros decisórios de políticas públicas para agências reguladoras." (TORRES, 2017, p 358), a fim de aumentar o controle social e a democratização da gestão, e, consequentemente, abriu caminho para as terceirizações e parcerias públicoprivadas. Em suma, o interesse centrava-se nas “[...] fatias do orçamento público e as oportunidades de investimentos para o capitalismo monopolista globalizado" (TORRES, 2017, p 358), essenciais para o momento de superação da crise do capitalismo, ou seja, para a reconfiguração das bases estruturais do sistema que se encontrava em transição para o século XXI. Assim, nota-se a captura de dos interesses de grupos privados pelas agências reguladoras, apoderando-se das fatias orçamentárias do Estado.

Uma das práticas patrimonialista, como o clientelismo, que resistiu e ainda resiste, devido à cultura patrimonialista que está inserida na sociedade brasileira e caracteriza forte resistência, sendo necessário mudar a mentalidade dos servidores públicos.

A mentalidade cultural foi um dos problemas encontrados tanto para a implantação da administração gerencial quanto da administração burocrática. O predomínio da raiz cultural voltada para o patrimonialismo contribuiu para travar o desenvolvimento do gerencialismo porque dependia do estágio racional em que se encontrava a burocracia. Contudo, é importante destacar que o gerencialismo foi inserido em um cenário do neoliberalismo e que interferiu diretamente na forma do Estado e na forma de governo, nesse caso, na democracia.

Os esforços empreendidos pelo Mare e, posteriormente, pelo Ministério do Planejamento, Orçamento e Gestão, segundo Torres (2004, p. 203), lograram poucas mudanças quanto à mentalidade dos servidores públicos, pelo simples fato de a transformação cultural ser muito lenta e de difícil percepção imediata. A forte presença da cultura patrimonialista na sociedade refletiu com mais intensidade no setor público. Apesar dos avanços, ainda presenciamos práticas patrimonialistas envolvidas nos mantos do clientelismo, bloqueando a consolidação da adoção e divulgação de uma cultura gerencial na administração pública federal. 
Nessa conjuntura, o país que tem a democracia consolidada, alto nível de desenvolvimento da cidadania e do capital social, da participação social e da accountability, não será o modelo gerencial PSO adaptável a essa forma de sociedade. Pois, as necessidades e as complexidade das organizações ao se adaptarem aos cenários de mudanças e transformações, irão desenvolver novos conceitos de administrar o Estado.

A EC 19/1998 foi instituída em um cenário no qual os atos institucionais redefiniram as relações e funções dos vários órgãos e entidades do Estado, para melhor executarem as tarefas essenciais à implementação do plano neoliberal conduzido por uma elite capitalista que detém o poder político e econômico. Sendo assim, conforme Tura (2001, p. 100), a separação entre administração burocrática, patrimonialista e gerencial não se deu da maneira definida por Bresser-Pereira, e o espírito público e competência da burocracia brasileira continuaram a satisfazer apenas o interesse de uma minoria que se apropria dela para priorizar seus interesses, e não o coletivo, pois tinha a ciência de sua importância para as elites.

A reforma gerencial de 1998 se baseou para manter as demandas do capitalismo e as demandas sociais. Assim, Bresser-Pereira (1998) propõe o modelo social-liberal, isto é, o modelo republicano de Estado, para que a reforma gerencial (PSO) obtivesse êxito. Todavia, é inegável os avanços na administração pública federal com a adoção de práticas como a transparência, a participação, a prestação de contas e controle social.

Portanto, ao analisar a convergência desses modelos e como se comportaram em suas adoções, demonstraremos, sob a luz das reformas administrativas, o que de fato foi superado ou apenas regulado para atender os interesses de grupos que detinham o poder político no país.

\subsection{Interseção dos modelos da administração pública brasileira}

A implantação dos modelos de administração pública no Brasil serviu para a sobrevivência política dos líderes da época. O momento histórico em que ocorreram as reformas administrativas era de regimes autoritários, a reforma burocrática do governo Vargas e a reforma administrativa de 1967 do golpe militar.

Diante da necessidade de se modernizar para responder às demandas do capitalismo, bem como para obter apoio político, os modelos de administração pública não foram adotados de forma radical. Assim, tem-se uma administração pública retalhada que até hoje preserva práticas patrimonialistas como uma das formas de sustentação política.

O quadro 7 demonstra, por meio das reformas da administração pública federal, as principais práticas adotadas e como elas se alteraram e convergiram nos últimos anos, 
principalmente com a regulação do DL 200/1967 e a EC 19/1998.

Quadro 7 - Evolução das práticas na administração pública no Brasil

\begin{tabular}{|c|c|c|c|}
\hline Práticas & Patrimonialista & Burocrático & Gerencial (EC n 19/1998) \\
\hline $\begin{array}{l}\text { Cargos, } \\
\text { Salários e } \\
\text { Carreiras }\end{array}$ & $\begin{array}{l}\text { Ausência de } \\
\text { competências e } \\
\text { hierarquias } \\
\text { claramente } \\
\text { reguladas em } \\
\text { leis. } \\
\text { Cargos em } \\
\text { excesso e } \\
\text { ausência de } \\
\text { plano de } \\
\text { carreira. }\end{array}$ & $\begin{array}{l}\text { Classificação de cargos do } \\
\text { poder executivo (Lei no } 3780 / \\
1960 \text { ) e das autarquias } \\
\text { federais (Lei no 5645/1970), } \\
\text { bem como das competências } \\
\text { dos ministérios (Decreto-lei } \\
\text { no }^{\circ} \text { 200/1967). } \\
\text { Decreto-lei no } \\
\text { não reduz cargos } \\
\text { administração direta; }\end{array}$ & $\begin{array}{l}\text { Premiação ou adicional através da } \\
\text { economia com as despesas } \\
\text { correntes; } \\
\text { somente lei de iniciativa dos } \\
\text { presidentes da República, do STF, } \\
\text { da Câmara e do Senado fixará o } \\
\text { subsídio dos ministros do STF; } \\
\text { Subsídio único para os membros de } \\
\text { poder ou detentor de mandato } \\
\text { eletivo; } \\
\text { revisão geral anual da remuneração; } \\
\text { estabelece que subsídios dos } \\
\text { ministros STF como referência para } \\
\text { o teto máximo da remuneração dos } \\
\text { servidores de todos os poderes e de } \\
\text { qualquer nível de governo; } \\
\text { os planos de carreira se intensificam } \\
\text { nos anos } 90 \text {. }\end{array}$ \\
\hline $\begin{array}{l}\text { Formação } \\
\text { e } \\
\text { Capacitaçã } \\
\text { o de } \\
\text { profissiona } \\
\text { is }\end{array}$ & $\begin{array}{l}\text { Ausência de } \\
\text { formação de } \\
\text { quadros } \\
\text { profissionais; } \\
\text { manutenção de } \\
\text { acordos políticos } \\
\text { em troca de } \\
\text { cargos. }\end{array}$ & $\begin{array}{l}\text { Criação do Departamento } \\
\text { Administrativo do Serviço } \\
\text { Público (DASP), com o } \\
\text { Decreto-lei no } 579 / 1938 ; \\
\text { adoção de Concursos } \\
\text { Públicos pelo decreto-lei no } \\
\text { 1.713/1939, visou selecionar } \\
\text { candidatos mais capacitados } \\
\text { e reduzir o clientelismo; } \\
\text { exigência de concursos } \\
\text { públicos na administração } \\
\text { indireta na Constituição de } \\
1967 \text {. }\end{array}$ & $\begin{array}{l}\text { Reserva percentual de cargos em } \\
\text { comissão para servidores de } \\
\text { carreira; } \\
\text { exige a criação das escolas de } \\
\text { governos. }\end{array}$ \\
\hline $\begin{array}{l}\text { Controle } \\
\text { das } \\
\text { despesas; }\end{array}$ & $\begin{array}{lr}\text { Ausência } & \text { de } \\
\text { controle } & \text { das } \\
\text { despesas; } & \\
\text { ocorriam } & \\
\text { pagamentos em } \\
\text { dinheiro de } \\
\text { forma direta: } \\
\text { "pagamento por } \\
\text { fora". }\end{array}$ & 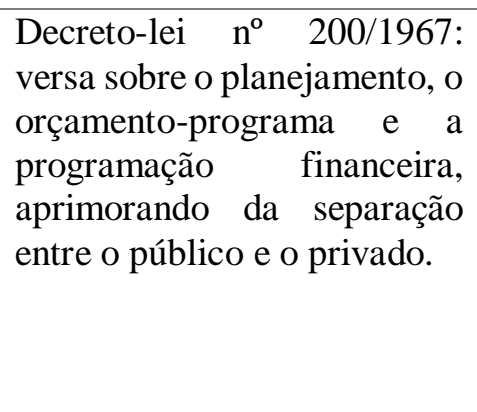 & $\begin{array}{l}\text { Incentiva o controle social: os três } \\
\text { poderes publicarão anualmente os } \\
\text { valores do subsídio e da } \\
\text { remuneração de seus servidores. }\end{array}$ \\
\hline $\begin{array}{l}\text { Regime } \\
\text { Jurídico } \\
\text { Único - } \\
\text { Estatuto do } \\
\text { Servidor }\end{array}$ & Ausente & $\begin{array}{l}\text { Regulação de estatuto dos } \\
\text { servidores (Decreto-lei } n^{\circ} \\
1.713 / 1939) \text {. }\end{array}$ & $\begin{array}{l}\text { Flexibilização da estabilidade do } \\
\text { servidor público; } \\
\text { insuficiência de desempenho passa a } \\
\text { ser passível de punição com a perda } \\
\text { do cargo. }\end{array}$ \\
\hline
\end{tabular}




\begin{tabular}{|c|c|c|c|}
\hline $\begin{array}{l}\text { Quadros } \\
\text { qualificado } \\
\text { s para } \\
\text { exercer as } \\
\text { atividades } \\
\text { do Estado }\end{array}$ & $\begin{array}{lr}\text { Não havia } \\
\text { regulação para os } \\
\text { cargos } \\
\text { qualificados para } \\
\text { exercer } \\
\text { atividades } \\
\text { Estado. }\end{array}$ & $\begin{array}{l}\text { Não havia regulação para } \\
\text { definir os cargos qualificados } \\
\text { como exclusivos para exercer } \\
\text { as atividades do Estado. }\end{array}$ & $\begin{array}{l}\text { Estabelece critérios diferenciados de } \\
\text { remuneração, admissão e demissão } \\
\text { de servidores que desenvolvam } \\
\text { atividades exclusivas de Estado. }\end{array}$ \\
\hline $\begin{array}{l}\text { Responsabi } \\
\text { lização e } \\
\text { Transparên } \\
\text { cia }\end{array}$ & $\begin{array}{l}\text { Ausente, } \\
\text { predomínio da } \\
\text { corrupção e da } \\
\text { extorsão }\end{array}$ & $\begin{array}{lr}\text { Regulação } & \text { da } \\
\text { Responsabilização fixado no } \\
\text { Decreto-lei no } \\
\text { através dos } & \text { princípios } \\
\text { fundamentais, } & \text { do } \\
\text { planejamento, do orçamento- } \\
\text { programa, da programação } \\
\text { financeira e da } \\
\text { ministerial. }\end{array}$ & $\begin{array}{l}\text { Accountability - prestação de } \\
\text { contas sobre o dinheiro, bens e } \\
\text { valores públicos; } \\
\text { Transparência - publicação dos } \\
\text { subsídios e remuneração dos cargos. }\end{array}$ \\
\hline $\begin{array}{l}\text { Descentrali } \\
\text { zação e } \\
\text { Participaçã } \\
\text { o }\end{array}$ & $\begin{array}{l}\text { Totalmente } \\
\text { centralizado na } \\
\text { figura do Rei }\end{array}$ & 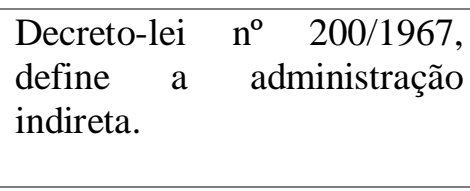 & $\begin{array}{l}\text { Participação }- \text { refere sobre a } \\
\text { participação do usuário nos serviços } \\
\text { público. }\end{array}$ \\
\hline Autonomia & Ausente & Ausente & $\begin{array}{l}\text { Cria o contrato de gestão do serviço } \\
\text { público, possibilitando maior } \\
\text { autonomia gerencial, financeira e } \\
\text { orçamentária aos administradores, } \\
\text { ampliando a autonomia dos órgãos } \\
\text { públicos mediante a negociação } \\
\text { entre administradores e poder } \\
\text { público; } \\
\text { permite que as empresas públicas e } \\
\text { as sociedades de economia mista } \\
\text { tenham regulamento próprio para } \\
\text { compras governamentais }\end{array}$ \\
\hline
\end{tabular}

Fonte: Elaboração própria.

Destacam-se as práticas mais comuns dos modelos de administração pública brasileira, sobretudo na administração de pessoal, a qual demonstrou que, desde sua administração patrimonial até e a implantação da administração gerencial, ocorreram as maiores alterações.

Como será descrito no capítulo quatro, a regulamentação e desregulamentação da administração pública federal partiu da necessidade de suprimir o patrimonialismo. A administração burocrática e a gerencial convergiram e mantiveram algumas práticas coloniais.

Algumas das ações mais comuns no patrimonialismo, os excessivos números de cargos, a ausência de planos de carreira, o desinteresse em formar quadros qualificados, a ausência de quadros exclusivos de Estado e a ausência de controle perseveram até hoje, e embora haja, ao menos, um esforço para superá-las, ainda ocorre de forma letárgica. Assim, nota-se, na EC 19/1998, que ao melhorar a eficiência administrativa, a maioria dessas práticas são efetuadas para fortalecer a administração burocrática. 
Nesse contexto, como exemplo, tem-se a adoção de práticas como a reserva percentual de cargos em comissão para servidores de carreira, a flexibilização da estabilidade do servidor público e a insuficiência de desempenho passa a ser passível de punição com a perda do cargo, a exigência de criação das escolas de governos e o estabelecimento de critérios diferenciados de remuneração, admissão e demissão de servidores que desenvolvam atividades exclusivas de Estado.

Os procedimentos supracitados deveriam ser adotados na Era Vargas, para suprimir as práticas patrimonialista herdadas do período colonial, porém, somente foram regulamentadas em1998, efetivando a intersecção entre os modelos de administrar o Estado, reflexos de uma tomada de decisão sobre implantar as reformas administrativas gradualmente.

A prática patrimonialista, caracterizada pelos excessivos números de cargos, foi regulamentada pelo DL 200/1967, como também expandiu a possibilidade de aumentar através da administração indireta (não exigia concurso público). Nesse caso específico, os cargos foram utilizados para dar estabilidade política ao golpe militar de 1964. Contudo, a EC 19/1998 reduziu os cargos em comissão e também direcionou para os servidores de carreira. É importante salientar que o DL 200/1967 regulamentou apenas a administração federal, excluindo os estados e os municípios, por isso, a prática patrimonialista ainda é relevante para a manutenção da governabilidade. Além disso, a necessidade de planos de carreira que poderiam ser adotados na reforma burocrática de 1967 apenas ganhou atenção com a reforma gerencial de 1998, demonstrando claramente a convergência entre os modelos.

Outra prática que denota a intersecção é a descentralização. O modelo ideal burocrático no qual se baseou o DL 200/1967 visava ser centralizado, porém regulamentou a administração indireta (descentralização), criou as autarquias, as empresas públicas, as sociedades de economia mista e as fundações públicas.

A implantação da administração burocrática brasileira, mesmo com a aparente organização instituída por Vargas e, posteriormente, com outras medidas consagradas tanto nas constituições como nas leis que regulamentaram, segundo Costin (2010), não ocorreu "ideal", como aconteceu nos países centrais, que detinham uma burocracia mais próxima do modelo ideal. Isso fez com que a administração pública convivesse com a desprofissionalização própria da administração patrimonialista.

Nesse cenário, tem-se modelos que convergem e incompletos, sendo possível, com o DL 200/1967, ser constituído de base burocrática weberiana, e sinalizando umas das práticas gerenciais (descentralização), contudo, na execução, preservou uma das práticas patrimonialista que é a utilização das autarquias para nomear as indicações dos acordos políticos a fim de 
garantir apoio ao golpe militar de 1964.

O mesmo ocorreu em relação à reforma gerencial e a maioria dos países preservaram traços importantes da administração burocrática, tais como:

- carreiras estruturadas e com exigência de concursos públicos para atividades de policiamento, fiscalização, regulação e coordenação de políticas públicas; - exigência de procedimentos estruturados, incluindo licitações e tomadas formais de preços para compras governamentais e contratação de obras e serviços; - procedimentos previstos em leis e regulamentos para elaboração, movimentação e arquivamento de documentos oficiais; - mecanismos de proteção do servidor público contra perseguições políticas; - estruturas de controle interno e externo (que continuam a verificar inclusive adequação a procedimentos estabelecidos), mesmo na presença de uma sociedade vigilante e de contratação de empresas de auditoria. (COSTIN, 2010, p. 35).

A preservação dessas práticas burocráticas revelou à similaridade e a necessidade da administração gerencial de a se aprimorar para ser mais eficaz nas demandas do Estado liberal, assim, a administração pública federal caracterizou-se como "modernização" da administração burocrática, com uma nova "roupagem", a fim de conseguir agregar apoio político ao projeto. Diferentemente dos países centrais que já possuíam uma burocracia forte, foram utilizados conceitos gerenciais para aprimorar a administração pública.

O gasto elevado de pessoal fez a reforma gerencial, em boa parte, lidar com a administração de pessoal. A evolução nessa área se deu, certamente, para combater umas das práticas patrimonialista mais preponderantes, os esquemas clientelistas, que ainda seguem presentes nos cargos de confiança dos três poderes, com o objetivo de consolidar a profissionalização (COSTIN, 2010).

Portanto, com a necessidade de responder às pressões do capitalismo e da governabilidade, a forma de administrar o Estado brasileiro vem se remendando, enredando-se, para atender de forma gradual os interesses políticos vigentes. Em suma, procuramos demonstrar a regulamentação e desregulamentação da administração pública federal, comparando-as aos modelos ideais e destacando as principais práticas que passaram por mudanças e aquelas que ainda persistem.

\subsection{Considerações parciais}

Neste capítulo, tencionou-se demonstrar a desregulamentação e regulamentação, que são conhecida como reformas, dos modelos de administração comparando a definição ideal com o modelo adotado no Brasil. Foi possível perceber que o enredamento entre eles acarretou um 
modelo administrativo com disfunções e práticas coloniais ainda persistentes.

A proposta social-liberal de Bresser-Pereira (1998), que enfatizou a importância da democracia participativa, não teve o cuidado de relatar que o interesse em uma perspectiva neoliberal dominante apresentará riscos, de modo que a democracia seja a primeira a ser desrespeitada. A democracia só interessa quando esta se submete apenas aos interesses dos controladores dos investimentos. Assim, quando Bresser-Pereira (1998) propõe o modelo gerencial para o Estado republicano, ignora a perspectiva do modo do capitalismo lidar com a democracia, pois, quando a sociedade lograr de participação efetiva nos debates e decisões sobre seu destino, os grupos que detêm o poder não entendem como democracia, mas como crise da democracia (TURA, 2001).

O movimento por uma administração pública gerencial, definido pelo Plano Diretor da Reforma do Aparelho do Estado de 1995 e que versou sobre a necessidade de desregulamentar e desburocratizar, a fim de possibilitar a adoção de práticas gerenciais, utilizou-se da forma de governo da democracia participativa, mas o projeto final aprovado, teve todo seu desenvolvimento estruturado para dar respostas ao capitalismo, defendendo a necessidade de redução de gastos, privatização e contenção da crise fiscal.

Nesse cenário, determinou-se que o projeto de reforma do aparelho do Estado, ao eleger a administração pública gerencial e o público não-estatal, focasse na privatização de empresas estatais e na publicização dos serviços sociais, por meio das organizações sociais, o que para Torres (2017) definiu como um projeto liberal de modernização do Estado capitalista brasileiro. Obviamente, a reforma do aparelho do Estado conseguiu aprovação no congresso por atender às necessidades dos possuidores do poder que queriam obter vantagens "capitalizando" a burocracia nacional para melhor responder a seus interesses conduzidos pelo neoliberalismo.

Sendo assim, percebe-se que, quando se entra em contato com as organizações públicas com a necessidade de algum serviço público, é possível notar nitidamente que o gerencialismo não foi capaz de atender com eficiência às principais necessidades da população. A título de exemplificação, pode-se citar a situação da saúde, que se encontra, segundo Barnabé (apud NOVAES; DAL RI, 2017, p. 374), precarizada e de péssima qualidade, induzindo as pessoas para que procurem o sistema privado de saúde. Logo, é visível que a adoção gerencial não demonstrou eficácia nos resultados na área da saúde.

A reforma gerencial de 1998 visou modernizar a administração do Estado brasileiro acabou sendo influenciada por interesses neoliberais, demonstrando dificuldades na administração gerencial voltada para os cidadãos, já que, historicamente, a cultura da administração pública brasileira está sob o enraizamento patrimonialista, concebido sob a égide 
do insulamento burocrático de viés clientelista. Em síntese, temos o sentimento de que nada mudou, nem mesmo as práticas dos aparatos estatais, e isso ocorre pelo fato de ainda convivermos com traços do que há de pior nos modelos de administração pública antecedentes e, também, dos próprios limites do modelo gerencial brasileiro, configurando apenas um projeto de recomposição do aparato administrativo do Estado, com consequências para o desenho institucional das políticas públicas (TORRES, 2017).

Isto posto, foram expostos os avanços no combate às as práticas patrimonialistas, mas, também, sua persistência. Atualmente, a administração pública brasileira encontra-se enredada aos modelos de administrar o Estado, criando uma estrutura esquizofrênica e letárgica. Teve como base a necessidade de superar as práticas patrimonialistas com as reformas burocráticas e gerencial (aprimoramento da burocracia e inserção de novos conceitos). Nesse cenário, há, ainda, a existência de práticas, como o clientelismo, a troca de favores políticos por cargos e a corrupção, a serem suprimidas da administração do Estado brasileiro.

Portanto, um dos maiores desafios para a administração pública é desenvolver a consciência da população, transformando a sua cultura, pois a interferência irá garantir o serviço público melhor. Diferentemente ocorrerá ao exclui-la da efetiva decisão (ficando para os tecnocratas), desenvolvendo morosamente a transparência, a participação e o controle social. No entanto, é inegável que, mesmo com cenário desfavorável, as reformas da administração pública brasileira vêm demonstrando avanços, pois inserem conceitos essenciais que até então eram inexistes na administração pública federal, como a transparência, a participação, a prestação de contas e o controle social. Porém a modernização e a racionalização ocorrem conforme o "espirito" de seu tempo. 


\section{AS DIVERSIDADES DAS REFORMAS}

Como descrito no capítulo dois, o Estado moderno dispõe de um conjunto de decisões e a responsabilidade pela execução das decisões é da administração pública. Assim, o Estado é a “[...] instância que organiza a sociedade numa determinada estrutura de poder” (COSTIN, 2010, p. 04), sendo o governo sua forma de atuação (democrático) e a administração pública composta por órgãos e pessoas que executam a operacionalizam suas diretrizes na forma de prestação de serviços públicos, fiscalização, regulação e exercício de funções de soberania.

Em 1998, ocorreu a reforma do aparelho do Estado a fim de melhor prestar os serviços aos cidadãos. Para tanto, foi necessário desregulamentar as normas vigentes e regulamentar, incluindo novos conceitos ${ }^{24}$. Com isso, a desregulamentação da administração pública ocorreu quando se modificou sua forma, alterando ou criando novas regras, isto é, quando houve a alteração do modelo burocrático para o modelo gerencial, também alterou a legislação vigente, para adoção dos conceitos pós-burocráticos, como o gerencial.

Nesta pesquisa, utilizou-se a desregulamentação como uma ação governamental para desmontar as normas existentes, e a regulamentação para instituir novas regras, a fim de redesenhar o aparelho do Estado, sua forma de administrar.

O tema surgiu nas discussões e nas medidas governamentais com ênfase restrita ao aspecto de desmontar as normas existentes - desregulamentação carecendo, porém, de uma linha definidora de ação e de enfoque em outros aspectos relevantes como as novas regulamentações requeridas por um novo desenho do Estado. (INSTITUTO DE PESQUISA ECONÔMICA APLICADA, 1993, p. 27).

A desregulamentação e a regulamentação, também caracterizada como reforma, são processos constantes e essenciais para consolidar as transformações da forma de administrar o Estado, que variam conforme as decisões do grupo dominante no poder. Segundo Nerling (1997), a necessidade de domesticar o monstro da burocracia para melhor servir às pessoas e ceder espaço para a realização de novas experiências perpassa a compreensão da burocracia entendida como "[...] teias de aranha feitas para atrapalhar o homem em seu tempo e paciência, para concebê-la como um sistema formal onde a autoridade está sujeita à princípios e normas racionais escritas." (NERLING, 1997, p. 51). A desregulamentação e regulamentação foram criadas para domesticar o monstro da burocracia e superar as "teias de aranha" geradas com a finalidade de atrapalhar sua eficiência.

\footnotetext{
${ }^{24}$ Ver capítulo três.
} 
O quadro a seguir apresenta a definição dos conceitos de regulação, desregulação, regulamentação e desregulamentação.

Quadro 8 - Definição de regulação, desregulação, desregulamentação e regulamentação

\begin{tabular}{|l|l|l|l|}
\hline Regulação & $\begin{array}{l}\text { É o conjunto de normas que, } \\
\text { ao serem aplicadas a uma } \\
\text { organização ou sistema, } \\
\text { permitem alcançar a } \\
\text { estabilidade. Quando não há } \\
\text { regra, o primeiro ato ao } \\
\text { instituir será para regular. }\end{array}$ & $\begin{array}{l}\text { É o conjunto de normas } \\
\text { que irão substituir a } \\
\text { regulação vigente, } \\
\text { apresentando um novo } \\
\text { desenho institucional. }\end{array}$ \\
\hline Desregulaçãa & $\begin{array}{l}\text { É deixar de estar regulado, } \\
\text { ausência de normas para } \\
\text { estabilizar, equilibrar. Estado } \\
\text { sem lei, normas de interesses } \\
\text { privado. }\end{array}$ & Desregulamentação & $\begin{array}{l}\text { É ênfase restrita ao } \\
\text { aspecto de desmontar a } \\
\text { regulação existente. }\end{array}$ \\
\hline
\end{tabular}

Fonte: Elaboração própria.

A partir dos conceitos apresentados no quadro 8, pode-se afirmar que o período colonial, ou o Estado Absoluto, teve sua administração como patrimonial, um Estado desregulado, pois os interesses particulares eram a prioridade em relação aos interesses públicos. A administração burocrática, por sua vez, visando a total separação entre o público e o privado, instituiu a regulação burocrática, criando normas que não existiam. Com a administração gerencial, foi necessário mudar as normas vigentes (desregulamentação) e adotar novas regras (regulamentação) para um novo desenho institucional, gerando, por meio das reformas.

\subsection{Desregulação patrimonialista da administração pública}

O Estado patrimonialista é uma forma legítima de exercer o poder político e sua sustentação está garantida por sua forma de dominação, a dominação patrimonialista. Sob a dominação por uma autoridade, o governante se apropria do aparato administrativo e exerce seu poder político exclusivamente para atender seus interesses.

Segundo Faoro (2012), na monarquia patrimonialista, o rei se eleva sobre todos os súditos, senhor da riqueza territorial, dono do comércio e conduz toda a riqueza sendo capaz de "[...] gerir as maiores propriedades do país, dirigir o comércio, conduzir a economia como se fosse empresa sua" (FAORO, 2012, p. 36). A adoção da visão religiosa do exercício da autoridade real tornava o rei investido de poder pela providência divina e legitimava 
(dominação tradicional) sua imagem de protetor e proprietário de seus séquitos, impondo lealdade ao rei e não à nação. Assim, todo o período colonial era desregulado, pois a regulação mínima que ocorreu a respeito da administração do Estado brasileiro serviu apenas ao propósito de responder aos interesses pessoais do rei e de seus grupos.

A administração patrimonialista do Estado brasileiro iniciou-se com a vinda da Coroa Portuguesa ao Brasil, com a necessidade de garantir, através de uma norma mínima, os interesses da corte e do rei. A monarquia portuguesa trouxe um sistema político-administrativo baseado na confusão entre a relação do que é público e do que é privado, na concessão de cargos em troca de lealdade política, amizade ou interesses partilhados. A ausência de discriminação normativa para aplicar as rendas e despesas, misturando o que constituía as despesas da família com os serviços de interesses públicos. Para Faoro (2012, p. 25) as rendas e despesas eram aplicadas "[...] sem discriminação normativa prévia, nos gastos de família ou em obras e serviços de utilidade geral". Essas práticas foram caracterizadas por Weber (2014) como patrimonialismo.

No modelo patrimonialista, a distinção entre o público e o privado é desconhecida. A administração pública é tratada pelo rei como assunto de interesse puramente pessoal, bem como o patrimônio é adquirido em função de emolumentos e tributos. Por essa razão, o patrimonialismo é a apropriação do Estado para fins de interesse pessoal. No período colonial, por mais que houvesse algumas normas, todas eram aplicadas para atender às demandas do rei e de seus séquitos, não visando os interesses da nação. Desse modo, a desregulação sempre contemplou os interesses da corte e dos grupos que a envolvia, consolidando a formação da administração pública patrimonialista brasileira.

$\mathrm{Na}$ administração patrimonialista, toda a movimentação de bens contava com a participação do rei, sendo "senhor ele próprio de todas as transações, lucros e vantagens" (FAORO, 2012, p. 51). Dessa forma, a monarquia patrimonialista é “[...] o titular da riqueza eminente e perpétua, capaz de gerir as maiores propriedades do país, dirigir o comércio, conduzir a economia como se fosse empresa sua." (FAORO, 2012, p. 51) e, consequentemente, prendendo os servidores numa rede patriarcal, representando uma extensão da casa do soberano.

Essa rede patriarcal instituída, trata a administração pública como o serviço doméstico do rei, passando a distribuir os cargos públicos a seu prazer e interesses, dividindo as funções com a fidalguia. A troca de benefícios constitui a base da atividade pública, dissociada de interesses reunidos numa única convergência: o poder e o tesouro do rei (FAORO, 2012). Nesse contexto, toda relação no período colonial foi orientada pela troca de interesses e os grandes cargos da administração pública, como uma moeda essencial para a manutenção dos séquitos e do poder 
político (hoje conhecido como governabilidade), inchando o Estado de funcionários, bem como refletindo e desenvolvendo uma administração pública lenta e pesada.

As práticas supracitadas geraram a legitimação de uma estrutura política de Estado patrimonialista, sendo composto pelo estamento de militares e funcionários, sendo esse quadro administrativo submisso ao comércio. O patrimonialismo se fechou sobre o estamento, de caráter marcadamente burocrático. Uma burocracia não no sentido moderno, como aparelhamento racional, mas da apropriação do cargo. Assim, as orientações de comando proferidas pela autoridade eram baseadas em valores, opiniões e posições pessoais do rei (FAORO, 2012).

A organização administrativa e política no período colonial não derivou de sua própria sociedade, não surgiu como uma transformação do seu tempo espaço, mas como uma couraça disforme, vinda de fora. Ela é complexa e não corresponde à população, principalmente a sociedade colonial brasileira, como uma "[...] fisionomia ganglionar, rarefeita, dispersa, em estado de dissociação intensa" (FAORO, 2012, p. 143). A inviabilidade da complexidade administrativa e política criou uma dependência morta, passiva e estrangulada, tornando o Estado não o protetor dos interesses da população, mas o defensor das atividades dos particulares (ausência de Estado regulado, sem lei, portanto, desregulado). Esse Estado foi caracterizado como um " [...] monstro sem alma, o titular da violência, o impiedoso cobrador de impostos, o recrutador de homens para empresas com as quais ninguém se sentirá solidário." (FAORO, 2012, p. 143), servindo apenas aos buscadores de benefícios escusos e de cargos públicos.

Nessa conjuntura, a desregulação no período colonial teve sua base de decretos, alvarás e ordens régias, numa terra "[...] inculta e selvagem, desconhecida e remota, recebe a forma, do alto e de longe, com a ordem administrativa da metrópole" (FAORO, 2012, p. 129). A ausência do desenvolvimento de normas de acordo com as necessidades do país fez com que adotássemos a forma de governo e os princípios da política conforme os interesses do rei, de modo que o país herdou o mesmo modelo administrativo vigente em Portugal, que se adaptou às necessidades da corte.

O patrimonialismo brasileiro desenvolveu-se para garantir os contratos rendosos para a corrupção, as luvas aos intermediários e governadores. Os cargos serviram para premiar a nobreza ociosa. Instaurado o sistema, suas práticas se consolidaram nos partidos políticos e os mesmos passaram a se moldar para obter emprego, favores e benefícios aos cabos eleitorais.

Para Faoro (2012), o sistema patrimonialista encontrou estabilidade apoiada pelo coronelismo. Ao aprovar a descentralização, que determinou aos governadores organizar os 
municípios na feição que melhor os interessasse, a política dos governadores, apoiada pelo aliciamento eleitoral, legitimou a ordem e consolidou a dominação patrimonialista.

A burocracia desenvolvida no período colonial, segundo Faoro (2012) adquiriu as feições aristocráticas da nobreza, da toga e do título; formou o estamento burocrático, capaz de absorver e adotar práticas patrimonialistas. Esse modelo ficou caracterizado como um Estado paternalista em essência, apropriado por um líder e estamental. A institucionalização desse modelo de administrar o Estado se padronizou e, a partir dele, estruturou a Independência, o Império e a República do Brasil. Portanto, o patrimonialismo marcou o desenvolvimento do Estado brasileiro e suas práticas se perpetuaram na administração pública brasileira até hoje, causando danos irreversíveis e prejudicando a quem mais precisa do Estado. Assim, para tentar superar essas práticas que pertenciam a uma administração patrimonialista desregulada, nos anos de 1930, deu-se início à regulação de práticas proposta pelo tipo ideal da administração burocrática descrita por Weber (2014).

\subsection{Regulação burocrática da administração pública}

O cenário no período colonial era de uma administração pública desregulada, voltada apenas para os interesses da corte. Era necessário regular a administração do Estado brasileiro, tornando-o racional, sobretudo com o objetivo de separar o público do privado. Além disso, o Estado brasileiro devia uma resposta mais eficiente ao capitalismo industrial, para que pudesse atender aos interesses de grupos emergentes. Assim, instituiu-se a República.

No entanto, somente no período Vargas iniciou-se o processo de minimizar as práticas patrimonialistas com a adoção do modelo burocrático weberiano. Segundo Costin (2010, p. 47), a República trouxe alterações à máquina administrativa, porém, manteve algumas práticas patrimonialistas, a saber, a troca de cargos e favores e a lealdade política. Essas alterações na administração pública brasileira serviram para regular as práticas burocráticas, desenvolvendo um novo desenho da administração pública, a racional-legal.

O enfrentamento das práticas patrimonialista na administração pública brasileira teve início com a necessidade de adotar uma concepção de administração mais técnica e racional, contrapondo a visão personalista e paternalista, além de responder às demandas exigidas pelo capitalismo industrial.

O novo desenho de administração pública baseado através da dominação racional-legal com administração burocrática de Weber (2014) exigiu alterações da cultura organizacional da administração pública federal, propondo principais conceitos, como a adesão de rotinas 
racionais e impessoais numa estrutura hierarquizada e o aumento dos níveis de burocratização. Para tanto, a fim de evitar o clientelismo e trocas de favores, a administração pública se fundamentou em conceitos como a hierarquização de autoridade; normas extensivas e impessoais; separação entre administração e propriedade; tornar a seleção, o salário e as promoções baseadas na competência técnica.

Após a Revolução de 1930, a reforma político-administrativa instituiu as normas, conferindo um novo formato de administrar o Estado baseado no modelo "ideal" burocrático weberiano. Principiou-se com a adesão de rotinas racionais e impessoais numa estrutura hierarquizada e aumentou os níveis de burocratização. Contudo, a transição foi incremental entre os modelos (o patrimonialista e o burocrático), mas preservando algumas práticas patrimonialistas, como, por exemplo, da administração "particularista" de pessoal. Com a mudança de foco, contrariando o conflito por cargos menores na política clientelista, permitiuse que os procedimentos se tornassem racionais, visando à precisão e à eficiência.

Em 1934, a administração pública adotou o concurso público para o ingresso no funcionalismo de carreira do Estado, a fim de atender às novas exigências dos padrões de trabalho. Criou, também, a fundação do Departamento Administrativo do Serviço Público (DASP), em 1938, e instituiu o estatuto para os funcionários públicos, em 1939.

Segundo Costin (2010), a reforma administrativa na Era Vargas baseou-se nos princípios de administração dos países avançados e tencionou modernizar a administração de pessoal, a administração de materiais, o orçamento e os procedimentos administrativos. A reforma alterou o nível da decisão das políticas públicas da esfera local para a burocracia central do governo, em um movimento de centralização, desenvolvendo uma conjunção muito mais complexa de fatores e atores sociais. Esses sãos alguns dos fatores que fizeram a administração pública federal atingir a era burocrática.

A adoção do modelo burocrático tinha como um dos objetivos evitar a influência direta dos políticos que apoiavam o governo nas escolhas dos cargos, tornando-os mais racionais e autônomos.

A situação da administração pública brasileira era então [até 1930] das mais lamentáveis, pois fora submetida, durante largos anos, a um regime eminentemente político, em que a escolha para os cargos públicos se fazia sob pressão dos políticos que apoiavam o governo. (LOPES, 1986 apud PAIVA, 2009, p. 787).

Como o depoimento de Lopes permite notar, deu-se o início ao enfrentamento da troca de favores políticos com a utilização de cargos públicos para manter o apoio político, contudo, 
essa postura não foi suprimida em 1930 e permanece até hoje como base de negociação para conquistar a governabilidade.

Após a adoção de práticas burocráticas, Graham (1968) realizou entrevistas com os funcionários públicos e encontrou, na administração pública federal, uma suposta inadequação das técnicas administrativas, dificuldade de organizar um programa de treinamento de pessoal, ausência de um plano de salários racional em um quadro de economia inflacionária, a inexistência de um plano de classificação das posições e, por fim, a lenta mobilidade dentro da estrutura funcional. Ao retratar esse cenário, Graham (1968) não só percebeu a burocracia e a administração pública como fenômenos estritamente técnicos, como também não a tratou como um rompimento absoluto entre o modelo patrimonialista e o burocrático. Apontou, ainda, que havia importante interação entre ambas. Todavia, o papel da burocracia era fundamental para organizar e distribuir os objetivos, muitos dos quais diferentes entre si.

Para compreender melhor a interação entre as práticas patrimonialistas e burocráticas, tem-se o clientelismo e coronelismo como exemplo de práticas que persistiram. Porém, é necessário compreender até que ponto a sociedade brasileira estava em sintonia com as mudanças e, concomitantemente, se as adoções de modelos estrangeiros estavam sincronizadas com a sociedade brasileira. Pode-se afirmar que a reforma burocrática constituída "de cima para baixo" se conectava em partes com a sociedade, caso contrário, o projeto fadaria ao fracasso. Entretanto, a supressão total das práticas tradicionais foi algo que efetivamente não ocorreu.

O cerne da reforma burocrática constituiu-se em desenvolver a administração pública para um modelo racional-legal, desafiando o patrimonialismo e as manobras mais articuladas dos partidos políticos, que, habitualmente, premiavam os serviços prestados com cargos públicos. A adoção do concurso público evidenciou que houve significativa diversificação de atores sociais na gerência da máquina pública brasileira.

Assim, a burocratização da administração do Estado brasileiro apresentou mudanças significativas no que tange à gestão de pessoal; com a criação de novos cargos, funções e órgãos administrativos, a máquina pública se transformou rapidamente em um organismo altamente complexo, em tese, ganhou em eficiência administrativa e perdeu em eficácia política, sobretudo com a tendência ao insulamento burocrático em alguns setores de decisão. Contudo, algumas práticas patrimonialistas persistiram mesmo após a adoção de práticas burocráticas na era Vargas, sendo necessário se concentrar em uma lei. Desse modo, a reforma administrativa, por meio do decreto-lei no 200 de 25 de fevereiro de 1967, avançou na adoção do modelo burocrático. 


\subsubsection{O decreto-lei $N^{\circ} 200$ de 1967}

Como discutido anteriormente, a administração patrimonialista foi o período da desregulação e a adoção da burocracia deu início à regulação. Após a adoção parcial das práticas burocráticas na Era Vargas, com o passar dos anos, notou-se a necessidade de reformar a administração do Estado brasileiro, em busca de uma lei eficaz para dar resposta às pressões do capitalismo. O cenário nos anos 60 apresentava um congresso acentuadamente paternalista e nepotista (práticas patrimonialistas) e, com a incapacidade do DASP, que já não tinha mais a mesma força, encontrava-se tecnicamente enfraquecido.

O DL 200/1967 teve como finalidade corrigir os desvios da regulação burocrática da Era Vargas. Visou alterar os hábitos que se enraizaram na administração pública brasileira, ou seja, erradicar a "[...] herança dos tempos coloniais e da característica paternalista do período 1930/1945.” (DIAS, 1969, p. 4). Por essa razão, foi necessário regulamentar a administração pública federal, que concentrou e adotou novas práticas burocráticas, que intentaram modernizar e descentralizar a administração pública brasileira.

O DASP já tinha perdido a importância de que dispunha na época e se apresentava como incapacitado. Não possuía informações básicas, como, por exemplo, o número de servidores públicos, nem sua classificação e distribuição. Esse problema gerou a necessidade de realização do Censo dos Servidores. Assim, ao deixar de ser dinâmico e de se apropriar dos estudos de reforma administrativa, tornou-se um "[...] organismo anêmico, contido por suas próprias indecisões, carente de atitude penitente para poder corrigir suas próprias omissões." (DIAS, 1969, p. 35).

Diante desse cenário do DASP e do descompasso entre as leis e a nova realidade do serviço público brasileiro, a reforma administrativa se revelou a missão na reconciliação das normas jurídicas, adequando-as à realidade administrativa do Brasil. Enfrentou, dessa forma, os problemas de uma burocracia sem inspiração e onerosa, resistindo a urgência em racionalizar (DIAS, 1969).

O DL 200/1967 consolidou os princípios fundamentais, quais sejam, o planejamento, a coordenação, a descentralização, a delegação de competências e o controle. Ao analisar pelo ponto de vista de organização das atividades administrativas, a importância do planejamento foi enfatizar um instrumento indispensável à administração, necessário para a formulação de diretrizes e controle dos objetivos sob a responsabilização do Estado.

A Reforma visou trabalhar a importância de conciliar a realidade da administração com a realidade legal, preparando-a para os administradores tomarem decisões e fazerem uma atuação 
socialmente eficaz. Além disso, refletiu a consciência generalizada de que a administração pública brasileira não poderia mais operar na "[...] base de improvisações incompatíveis com as responsabilidades do Poder Executivo, como principal gestor da Administração Federal.” (DIAS, 1969, p. 46).

Sendo assim, seguem alguns pontos que demonstram as condições da administração pública brasileira naquele momento:

A dificuldade em administrar eficiente devido à dimensão, a diversidade e a complexidade da organização do país; A organização da administração pública federal estava defasada com as necessidades do momento; A limitação do DASP em dar continuidade a um trabalho sistemático de aperfeiçoamento do serviço público. Resolvendo apenas questões temporárias ou de âmbito restrito; Os meios têm gradativamente se sobreposto aos fins, o acessório ao principal, o burocratismo à ação; A excessiva centralização administrativa, resultado da ausência de planejamento, diretrizes, organização. Tornando-se morosa às operações e encarecendo os custos. Reprimindo os órgãos da periferia próximos a coletividade ou dos problemas; Ausência de corpos de direção e assessoramento qualificados para o desempenho das funções, quadros estáveis, prevalecendo os princípios do bom recrutamento, seleção e contínuo aperfeiçoamento; A necessidade de institucionalizar o planejamento como método de bem administrar, o orçamento através do mecanismo do orçamento-programa, compatibilizar entre o que se deseja o que se pode realizar, o ajustamento do desembolso de caixa do Tesouro deve ajustar-se ao programa e à disponibilidade de recursos financeiros; Os sistemas de controle de que dispões a administração, tanto na execução dos programas como a responsabilidade financeira e orçamentaria dos agentes, são insatisfatórios. (DIAS, 1969, p.46).

Com base nessas prerrogativas, a reforma administrativa de 1967 concentrou-se em sedimentar sua fundamentação para romper com os equívocos e hesitações do passado, a fim de regular uma administração pública federal moderna e racional. Para Dias (1969), a reforma também tinha como escopo habilitar o administrador em todos os níveis hierárquicos, com a nítida ideia de que, para a administração funcionar a contento, era preciso conter alguns pontos de referência comuns e capazes de servir como alicerce à ação coordenada do todo e à atuação eficaz de suas partes componentes. Assim, o planejamento, a ação administrativa e o controle (nesse caso, a criação do controle interno e alterações de competências do Tribunal de Contas) foram os aspectos essenciais para habilitar o administrador moderno.

Além de regular o planejamento, o DL 200/1967 também institui o orçamento-programa, cuja finalidade era pormenorizar a etapa do programa plurianual e servir de roteiro à execução coordenada do programa anual. O orçamento-programa surge como um instrumento primordial para que o administrador estabelecesse uma linguagem comum entre o Poder Executivo e o Poder Legislativo, ao elaborarem e aprovarem o orçamento. Facilitou, ainda, a compreensão 
para o exato conhecimento do programa anual de trabalho governamental e os recursos alocados para sua execução, além de desenvolver a conciliação entre a programação de atividades e a estimativa dos recursos financeiros.

Dessa maneira, o orçamento-programa gerou "[...] a confiança de que as diretrizes do planejamento permearão os diversos níveis administrativos até atingirem as unidades executivas de menor porte." (DIAS, 1969, p. 58), determinando a responsabilidade pela execução dos serviços e a "[...] convicção dos órgãos executivos de que se ajustam às diretrizes da programação governamental, podendo pleitear e contar em tempo com os recursos indispensáveis ao desenvolvimento de uma ação dinâmica." (DIAS, 1969, p. 58). É possível notar, que o orçamento-programa é de suma importância para o administrador público se harmonizar com a programação econômica e social do governo.

O problema de relevância que precisava ser alterado referia-se à questão da qualidade do pessoal. A constatação da descontinuidade e da desatenção das simples normas da administração de pessoal, sob um contexto desfigurado, obrigou a submissão às seguintes orientações, que se mostravam necessárias:

1. Fixar diretrizes que permitam reformular a Administração do Pessoal Civil, através da revisão da legislação básica e da reforma dos esquemas de classificação e de remuneração; 2 . Sem prejuízo daquela reformulação, adotar providências imediatas que permitam encontrar solução para os problemas mais agudos; 3 . Atribuir a um órgão dedicado exclusivamente aos problemas de pessoal, subordinado diretamente ao Presidente da República, a responsabilidade pela formulação, orientação e coordenação da política de administração de pessoal; 4. Delinear a instituição de um corpo de assessoramento imediato do Poder Executivo, recrutado e selecionado segundo padrões especiais e sujeito a permanente processo de aperfeiçoamento. (DIAS, 1969, p. 69).

A partir dessas orientações, a reforma administrativa de 1967 versou sobre algumas normatizações, como a criação de um corpo técnico de assessoramento aos ministros, o estímulo a melhor composição dos cargos de chefia e direção e a instituição de um Centro de Aperfeiçoamento. O cenário quanto à administração de pessoal, que foi descrito por Dias (1969), era configurado com o aumento de gastos de pessoal, mas, consequentemente, reduzia a eficiência administrativa. A administração de pessoal demonstrava claramente a desorganização, a ausência de quadros técnicos, a falta de instrumentos e a composição de chefias praticamente esvaziada.

Em face desse cenário, a importância de valorizar e dignificar o servidor traria à administração pública um aumento na produtividade, gerando retorno à coletividade, assim 
como a profissionalização e o aperfeiçoamento do serviço público. Procurou-se, ainda, acentuar a importância do acesso e a escolha de ocupante nas funções de direção e assessoramento, com capacidade técnica para garantir a qualidade, produtividade e continuidade da ação governamental.

O DL 200/1967 estabeleceu cinco princípios fundamentais: o planejamento, a coordenação, a descentralização, a delegação de competência e o controle. Esses princípios tornaram-se a base para uma nova política administrativa desenvolvida e traduziu o reconhecimento e a necessidade dos princípios de serem executados, independentemente de qualquer governo. Também institucionalizou o controle interno e o primeiro escalão do governo passou a se responsabilizar pela gestão financeira na pasta competente.

A proposta de racionalizar os instrumentos básicos da administração pública federal, em especial o orçamento e a programação financeira, regulou que as despesas fossem aprovadas no legislativo, salvo aquelas em caráter autorizadas por crédito extraordinário, sendo um dos pontos essenciais na reforma administrativa. O DL 200/1967 contemplou, ainda, alterações nas normas relativas a Licitações para Compras, Obras, Serviços e Alienações e procurou alcançar três objetivos, sendo eles:

1. assegurar a mais ampla competição; 2 . proporcionar a obtenção de produtos, obras e serviços de comprovada qualidade; 3 . obter os menores preços possíveis no momento. Esse o núcleo de premissas em torno do qual as Normas foram concebidas, e deve servir de inspiração às disposições complementares a serem aprovadas em decreto, e, ainda, à aplicação das providências acolhidas pela Lei. (DIAS, 1969, p. 209).

Desse modo, visou a continuidade das operações, a fim de evitar as interrupções ou os descompassos que prejudicavam a coletividade. Houve, assim, a racionalização, a simplificação e o aperfeiçoamento do serviço público. Por fim, a simplificação das decisões administrativas, como a eliminação da mentalidade do processo, que se estabeleceu na tradicional burocracia nacional, resultou nos seguintes fatores:

1. falta de clara definição das atribuições dos órgãos; 2. ausência de precisão na definição de responsabilidade, especialmente da responsabilidade de decidir; 3. inexistência de diretrizes e de políticas que permitam aos responsáveis pelos escalões inferiores agir em consonância com o pensamento das cúpulas administrativas; 4 . falta de documentação junto ao órgão que lhe permita contar, prontamente, com os elementos e dados de que carece para resolver os casos que lhe são propostos; 5 . receio de decidir e consequente tendência de empurrar o caso para a decisão de outrem. (DIAS, 1969, p. 223). 
Esses fatores, ainda hoje, são os problemas a serem enfrentados na administração pública brasileira, que demonstra nitidamente a dificuldade de racionalizar a gestão e superar os vícios patrimonialistas. Contudo, a reforma administrativa de 1967 deu origem a uma perspectiva modernizadora quanto às concepções e métodos de ação, superando algumas práticas do passado.

\subsection{Desregulamentação burocrática}

O desenvolvimento do capitalismo e da democracia moderna passou a exigir respostas mais eficientes da administração do Estado, e as práticas que eram adotadas na iniciativa privada foram adaptadas para a administração pública, aperfeiçoando as práticas burocráticas para as práticas conhecidas como gerenciais ${ }^{25}$.

No Brasil, os primeiros indícios de adoção do gerencialismo ocorreram com a descentralização estabelecida no DL 200/1967. Contudo, foi a EC 19/1998 que se caracterizou como a reforma gerencial, aprimorando as práticas burocráticas weberianas e adotando as práticas gerenciais. Na época, a administração pública federal encontrava-se em uma situação caótica e totalmente desarticulada, revelando um cenário de incapacidade gerencial para a formulação, planejamento, execução e fiscalização de políticas públicas, sendo necessário adotar a eficiência como princípio.

Segundo Costin (2010, p. 28), o princípio da eficiência como norteador da Administração Pública foi inserido pela EC 19/1998, “[...] como se bastasse que a Administração Pública fosse impessoal, moral, governada pela lei e dessa publicidade a seus atos — não precisaria ser eficiente.”, assim, com a regulamentação, ampliou-se a necessidade de que os atendimentos à população fossem eficientes.

A adoção do modelo gerencial na administração pública brasileira não foi somente uma resposta à situação crítica em que se encontrava, mas havia também uma orientação internacional para realizar as reformas administrativas do Estado pelo mundo, principalmente nos países capitalistas. Sendo assim, centrou-se na importância de otimizar as ações do Estado para suportar suas demandas. Para adotar o gerencialismo, foi necessário desregulamentar as normas que definiam o modelo burocrático e regulamentar novas normas, que trariam um novo desenho para a administração pública federal. Portanto, descreveremos a desregulação do

\footnotetext{
${ }^{25}$ O modelo gerencial na administração pública brasileira, além de trazer novos conceitos, como a descentralização e a participação, também foi uma modernização do modelo burocrático brasileiro. (ver capítulo três).
} 
patrimonialismo brasileiro, a regulamentação e desregulamentação burocrática e, por fim, a regulamentação do modelo gerencial.

Antes de descrever como se iniciou a desregulamentação burocrática, é importante destacar alguns fatos históricos que ocorreram entre o período Vargas até a aprovação do DL 200/1967. O governo Juscelino, segundo Costin (2010, p. 56), também procurou modernizar a administração pública, criando, em 1956, a Comissão de Estudos e Projetos Administrativos (CEPA), que tencionava promover estudos para a Reforma Administrativa. A CEPA propôs a reestruturação de vários órgãos, simplificação do sistema de pagamento dos funcionários públicos, simplificação da elaboração, execução e controle orçamentários, utilização do princípio da descentralização da execução e centralização do controle, expansão do sistema de mérito e fortalecimento da autoridade do DASP. Todavia, o sistema de mérito e o fortalecimento do DASP não foram implementados.

Outro movimento importante que teve influência no DL 200/67 foi a criação do Ministério Extraordinário da Reforma Administrativa, sob a liderança de Amaral Peixoto. O ministro elaborou um plano de execução da reforma administrativa, porém não obteve sucesso em sua implantação, devido ao golpe de 1964. O governo militar atuou numa nova centralização do poder e restrição de liberdades individuais. Contudo, a abordagem sobre a coisa pública foi o “[...] caminho para a consolidação da administração burocrática e de redução do espaço dado ao clientelismo." (COSTIN, 2010, p. 56).

Em resumo, o DL 200/67 visou melhorar o controle sobre os recursos públicos e as práticas clientelistas e fisiologistas. Segundo Costin (2010, p. 59), também objetivou a estruturação das atividades exercidas pela administração pública, baseando-se no planejamento do desenvolvimento econômico-social do país, na coordenação, na descentralização das atividades, contratos ou concessões com o setor privado, delegação de competência e o controle sobre os meios, tanto o exercido pelo superior hierárquico quanto o controle de legalidade.

Após a implantação da reforma administrativa em 1967, surgiram algumas questões que precisavam ser modificadas, como, por exemplo, a necessidade de simplificar e dinamizar o funcionamento da administração pública federal, isto é, melhorar o atendimento aos usuários, o fortalecimento das pequenas e médias empresas, a transferência de atribuições ao setor privado e contenção da expansão da máquina pública mediante terceirização. Para tanto, em 1979, foi instituído o decreto $\mathrm{n}^{\mathrm{o}} 83.740 / 79$, que versou sobre o Programa Nacional de Desburocratização. O decreto apenas foi revogado em 2005, com a instituição do Programa Nacional de Gestão Pública e Desburocratização. 
De acordo com Torres (2004, p. 161), foi no período da reforma administrativa de 1967 e a promulgação da Constituição Federal de 1988 que se acentuou o processo de descentralização da administração pública federal, com a criação do Ministério da Desburocratização em 1979, idealizado por Hélio Beltrão, que ficou responsável pela pasta até 1983. A inovação ocorreu na mudança no modo de olhar para o contribuinte, que passou a ser tratado não mais como um súdito do Estado, mas como um cliente com direito a um serviço público de qualidade. Nesse contexto, já se pode notar uma sinalização ao modelo gerencial, que começou a ser discutido e implantado na Europa, o consumerism.

Em 1986, após a extinção do Dasp (início da desregulamentação burocrática), foi instituída pelo Governo Sarney a Secretaria de Administração Pública da Presidência da República (Sedap), vinculada diretamente ao gabinete da presidência, que ficou responsável pela modernização e racionalização da administração pública federal. A secretaria se destacou, destaca Torres (2004), pelo fortalecimento institucional da Escola Nacional de Administração Pública (Enap), pela criação do Cadastro Nacional do Pessoal Civil, pela extinção de 45 órgãos e comissões especiais e pela criação da carreira de gestor governamental.

Nos anos 90, com a instituição do decreto n ${ }^{\circ}$ 99.179/90, foi criado o Programa Federal de Desregulamentação vinculado à Presidência da República, e o decreto estabeleceu, em seus princípios, o respeito à liberdade individual, a defesa da livre concorrência e da competição nos vários mercados, o bom atendimento ao cidadão pela administração pública e a redução de custos dos serviços por ela prestados. Como base, foram definidos cinco objetivos: a privatização, a desregulamentação da economia, a desburocratização ou desregulamentação administrativa, o fortalecimento da sociedade civil e o federalismo e descentralização.

A atuação se desenvolveu sobre a desburocratização durante o período de sua existência. Segundo o Ipea (1993), a desburocratização incorporou os objetivos estabelecidos pelo antigo Programa Nacional de Desburocratização, voltados para eliminação de excessos e disfunções da burocracia, que complicava inutilmente a vida do cidadão. Além disso, também pretendia impedir o crescimento desnecessário da máquina administrativa federal e contribuir para a melhoria do atendimento aos usuários dos serviços prestados pelo Estado.

As medidas visaram resolver problemas que a administração pública apresentava, mas que ainda continuavam sem uma resolução efetiva. De acordo com o Ipea (1993), a incompetência era premiada, o apadrinhamento e o corporativismo prevaleciam sobre a profissionalização e a visão do serviço público, a rigidez da burocracia que limita a flexibilização e agilidade da gestão, o conformismo e a mediocridade são privilegiados, em detrimento da inovação e da competência. Por fim, o jogo político da conciliação de interesses 
contraditórios se sobrepõe às tomadas de decisões acertadas que são essenciais na administração pública. Esse cenário acarretou sérios danos à administração pública federal, entre eles, a descontinuidade administrativa, a politização clientelista, a malversação dos fundos, os baixos índices de efetividade operacional e a má qualidade na prestação de serviços públicos.

A necessidade de superar as mazelas herdadas ao longo da administração pública brasileira levou a, no final dos anos 90, serem parcialmente adotadas medidas conhecidas como gerenciais. A prática gerencial viria para superar a herança confusa e resistente das práticas patrimonialistas e de um modelo burocrático insuficiente e rígido e, para isso, o governo de Fernando Henrique Cardoso instituiu a emenda constitucional no 19 de 04 de junho de 1998.

Portanto, procuramos apontar as tentativas de desregulamentar práticas burocráticas por intermédio do movimento de descentralização, já que ainda persistiam as práticas patrimoniais, enredando-se com a administração burocrática e criando um modelo que não correspondia com eficiência à prestação de serviços públicos. Assim, apresentou-se um movimento de reforma, que viria a ocorrer de forma mais objetiva com um novo desenho institucional a partir da EC $19 / 98$.

\subsection{Regulamentação gerencial}

Para descrever a regulamentação da EC 19/1998, faz-se necessário comentar a dominação vigente e qual era a situação do capitalismo. Segundo Santos (2011), para Weber, somente o Ocidente conhece o Estado moderno, com uma “[...] administração profissional, um funcionalismo especializado e um direito baseado no conceito de cidadania." (SANTOS, 2011, p.142), isto é, o Ocidente conhece o direito racional elaborado racionalmente por juristas. Diferentemente das outras formas de dominação (carismática e tradicional), a dominação racional-legal com administração burocrática“[...] não é apenas uma característica de um tipo particular de ordem política, mas a sua característica central e dominante.” (SANTOS, 2011, p.142). Assim, a dominação racional-legal com administração burocrática é legitimada pelo sistema de leis dirigido por uma administração profissional, aplicada na sociedade como um tipo de justiça baseada numa racionalidade lógico-formal.

O capitalismo passou a ser o modo de produção dominante nos países centrais e a burguesia emergiu como a classe dominante no século XIX. A partir desse momento, tem-se todo o paradigma da modernidade associado ao desenvolvimento do capitalismo. Nesse contexto, o capitalismo será divido em três períodos: 
O primeiro, o período do capitalismo liberal, cobre todo o século XIX, embora as três últimas décadas tenham um caráter de transição; o segundo, o período do capitalismo organizado, começa nos finais do século XIX e atinge o seu desenvolvimento máximo no período entre as duas guerras e nas duas primeiras décadas do pós-guerra; finalmente, o terceiro período, o do capitalismo desorganizado, começa nos finais dos anos 60 e ainda continua. (SANTOS, 2011, p. 139).

A EC 19/1998 se insere no período do capitalismo desorganizado. Para Santos (2011), a designação "desorganizada" é ambígua e traiçoeira, pois o capitalismo desorganizado está mais organizado do que nunca. Capitalismo desorganizado significa,

[...] em primeiro lugar, que as formas de organização típicas do segundo período estão a ser gradualmente desmanteladas ou reconstituídas num nível de coerência muito mais baixo, e, em segundo lugar, que, precisamente por esse processo estar a decorrer, é muito mais visível a demolição de antigas formas organizativas do que o perfil das novas formas que irão substituí-las. (SANTOS, 2011, p. 153).

É no capitalismo desorganizado que surge a desregulamentação de antigas formas organizativas e a regulamentação de novas formas que irão substitui-las. Dessa maneira, o capitalismo conseguiu dominar todos os aspectos da vida social e neutralizou o movimento socialista, o ativismo operário, as relações sociais não-mercantilizadas. Entretanto, essa organização é “[...] muito opaca, e aquilo que já é visível parece bastante provisório, como se estivesse apenas a preparar o caminho para as instituições, as regras e os processos que hão-de constituir o novo modelo de regulação." (SANTOS, 2011, p. 153). Considera-se desorganizado por estar na transição de um regime de acumulação para outro, ou numa transição muito mais vasta, de um paradigma societal para outro.

O desmantelamento ou a reconstituição é o que consideramos como desregulamentação e regulamentação (reformas). A partir dos anos 1970, tem início as reformas gerenciais nos países centrais, em que os teóricos apresentaram uma orientação crítica da burocracia weberiana e desenvolveram o modelo gerencial.

Santos (2011, p. 155) ressalta que a relativa perda de protagonismo do Estado tem implicações diferentes em relação aos Estados do centro, da semiperiferia ou da periferia do sistema mundial, pois, com a crescente desigualdade entre o Norte e o Sul, os estados periféricos e semiperiféricos ficaram cada vez mais dependentes de cumprimentos das determinações do capital financeiro e industrial transacional (instituições controladas pelos Estados centrais). Sendo assim, essas determinações apresentaram base combinações estranhas de liberalismo econômico e de proteção dos direitos humanos e abalaram a tal ponto o já frágil componente 
social do Estado, que esses países assumiram a ideia de crise do Estado-Providência sem nunca terem usufruído verdadeiramente deste.

Os Estados centrais também exportaram

[...] instituições e normas jurídicas, ou até sistemas jurídicos completos, dos Estados centrais para os periféricos. Estes transplantes jurídicos eram resultado, nuns casos, de uma imposição colonial ou pós-colonial e, noutros, de uma adoção voluntária ou semi-voluntária. Noutros casos ainda, o direito (ocidental) moderno compartilhou o campo jurídico oficial com outras tradições jurídicas locais, sendo apenas dominante nas áreas consideradas mais importantes pelas elites políticas: as interações entre funcionários estatais e o mundo dos negócios. (SANTOS, 2011, p. 176).

Segundo Costin (2010), no Brasil, o mesmo ocorreu com importações de normas; dentre as várias medidas contidas na EC 19/1998, o contrato de gestão foi inspirado no modelo francês, reproduzido no parágrafo $8^{\circ}$ do artigo 37 da Constituição. Assim, o movimento de reforma gerencial estava sendo acompanhado pelos Estados centrais, para implantação da reforma administrativa de acordo com as determinações do neoliberalismo.

Dessa maneira, surgiu a necessidade de desregulamentar as práticas burocráticas consideradas rígidas, que deixavam a administração ineficiente em atender as demandas do capitalismo desorganizado e as concepções neoliberais. A acentuada crise fiscal que assolou o mundo foi um dos fatores determinantes para a administração pública implantar as reformas de cunho gerencial. No Brasil, seguindo o movimento mundial dos Estados centrais, a reforma gerencial foi implantada pela EC 19/1998.

A EC 19/1998 começou a surgir com os adventos do governo Collor na adoção de um plano caótico e desconexo de reforma administrativa, que teve como objetivo a extinção de milhares de cargos de confiança, reestruturação e extinção de muitos órgãos públicos, demissões de servidores sem estabilidade e servidores colocados em disponibilidade com remuneração integral (revogado na EC no 19/98). Segundo Torres (2004), a administração pública se encontrava totalmente desarticulada e desagregada, o que acarretou a perda de capacidade gerencial para a formulação, planejamento, execução e fiscalização de políticas públicas.

Além do quadro caótico em que se encontrava a administração pública federal, também havia uma pressão internacional para adoção de reforma administrativa do Estado, principalmente dos países capitalistas, baseando-se na importância de otimizar as ações do Estado a fim de otimizar as respostas às demandas do neoliberalismo. 
Desse modo, o governo Fernando Henrique Cardoso iniciou o trabalho para incluir na agenda nacional a discussão e implantação dos fundamentos da nova gestão pública. Com isso, a temática da reforma administrativa avançou na agenda governamental e foi capitaneada por Bresser-Pereira, ministro do recém-criado Ministério da Administração e Reforma do Estado (MARE).

Conforme Torres (2004), para ter uma clareza da estrutura e funcionamento da administração pública federal, em 1995, foi apresentado o Plano Diretor da Reforma do Aparelho do Estado. Esse estudo, fundamentado no modelo gerencial que estava sendo discutido e implementado em âmbito mundial, apresentou o diagnóstico da burocracia, apontando suas maiores deficiências, estrangulamentos, contradições e os objetivos a serem buscados pelo governo e pela sociedade.

O plano desenvolveu a proposta de elevar a administração do Estado a níveis mais altos de governabilidade e governança. No entanto, as propostas do plano diretor não tiveram aceitação dos servidores e refletiu no Congresso Nacional, criando resistência para a discussão e o fluxo mais intenso para o encaminhando dos objetivos propostos. Outro fator de resistência foi o núcleo dominante do governo FHC (Casa Civil, Ministério do Planejamento e Ministério da Fazenda), que, de forma cética, considerou o plano ambicioso demais e preferiu uma ação mais focada, gradual e incremental.

O plano diretor da reforma do aparelho do Estado considerou cinco frentes fundamentais para atuarem concomitantemente:

1) um ajustamento fiscal duradouro; 2) reformas econômicas orientadas para o mercado, que, acompanhadas de uma política industrial e tecnológica, garantam a concorrência interna e criem condições para o enfrentamento da competição internacional; 3) a reforma da Previdência Social; 4) a inovação dos instrumentos de política social, proporcionando maior abrangência e promovendo maior qualidade para os serviços sociais e 5) a reforma do aparelho do Estado, com vistas a aumentar sua 'governança', ou seja, sua capacidade de implementar, de forma eficiente, políticas públicas. (BRASIL, 1995, p. 11).

Dentre os cinco pontos, apenas o último ficou sob a responsabilidade do Mare; os demais dependiam de outros ministérios para avançar. Assim, segundo Costin (2010, p. 69), foram estabelecidas três dimensões como de responsabilidade do Mare: a dimensão institucional-legal (melhorar a eficiência), a dimensão cultural (enfrentar os resquícios patrimonialistas - criar a cultura gerencial) e a dimensão gerencial (práticas gerenciais). 
É importante destacar que o impulso gerencial da administração pública, como descrito anteriormente, parte de um modelo ideal desenvolvido nos Estados Unidos e na Inglaterra, países de referência nos avanços do sistema capitalista, que influenciou os países em desenvolvimento, servindo de fundamento na administração pública federal. Com a preocupação em reduzir gastos e melhorar a eficiência, a administração pública brasileira começou a exigir questões mais complexas, tais como "[...] efetividade, controle social, noções mais elevadas de cidadania, equidade e busca de maior responsabilização dos administradores públicos.” (TORRES, 2004, p. 173). Porém, quando o modelo gerencial se tornou mais complexo, refletiu suas peculiaridades e o estágio da administração em que se encontrava cada país, surgindo, assim, a variedade e multiplicidade de experiências gerenciais pelo mundo. Cada país que adotou as práticas gerenciais dependia do nível de desenvolvimento em que se encontrava a sua administração burocrática.

De acordo com Torres (2004), o sucesso do gerencialismo iria depender da qualidade burocrática, do nível de desenvolvimento da cidadania e do capital social, a accountability entre os três poderes, a trajetória histórica da administração pública e, obviamente, a vontade e força política dos defensores da reforma gerencial.

No Brasil, não foi diferente, e o país acompanhou a orientação mundial, direcionada pela crise fiscal e as disfunções burocráticas, que não mais correspondia ao capitalismo desorganizado. A EC 19/1998 encontrou um quadro resistente a mudanças, principalmente de setores mais organizados, como os servidores públicos federais, e um quadro político adverso. Contudo, a emenda garantiu alguns avanços e a adoção de práticas gerenciais como

1) Reserva percentual de cargos em comissão para servidores de carreira; 2) Assegura a revisão geral anual da remuneração; 3) Estabelece subsídios dos ministros STF como referência para o teto máximo da remuneração dos servidores de todos os poderes e de qualquer nível de governo; 4) Incentiva o controle social sobre a administração pública; 5) Amplia a autonomia dos órgãos públicos mediante negociação entre administradores e poder público; 6) Exige a criação das escolas de governos; 7) Estabelece critérios diferenciados de remuneração, admissão e demissão de servidores que desenvolvam atividades exclusivas de Estado; 8) Determina que o membro de poder ou detentor de mandato eletivo seja remunerado apenas por um subsídio único; 9) Lei de iniciativa dos presidentes da República, do STF, da Câmara e do Senado fixará o subsídio dos ministros do STF; 10) Para incentivar o controle social, os três poderes publicarão anualmente os valores do subsídio e da remuneração de seus servidores; 11) A economia com despesas correntes do órgão poderá ser revertida, inclusive sobre forma de prêmio ou adicional, para seus servidores; 12) Insuficiência de desempenho passa a ser passível de punição com a perda do cargo; 13) Flexibilização da estabilidade do servidor público; 14) Permite que as empresas públicas e as sociedades de economia mista tenham regulamento próprio para compras governamentais e; 15) Cria 
o contrato de gestão do serviço público, possibilitando maior autonomia gerencial, financeira e orçamentária aos administradores. (TORRES, 2004, p. 179).

Pode-se observar que os avanços da EC 19/1998 objetivaram maior liberdade e agilidade para a administração pública, moralização do Estado, regulação de garantias de capacitação profissional, flexibilização da estabilidade, ganhos de transparência e a valorização das carreiras do Estado. Essas foram medidas adotadas para combater a captura do Estado por interesses particularistas e corporativistas, a ausência de transparência e profissionalismo dos órgãos reguladores e para confrontar práticas que fogem ao interesse público.

Outras medidas foram, ainda, adotadas pelo governo federal, destacando-se, como descreve Torres (2004), a necessidade de reorganizar e racionalizar os processos e as estruturas administrativas, na tentativa de melhorar a qualidade da gestão, e, para tanto, foi criado o Programa de Reestruturação e Qualidade (PRQ) dos ministérios. O Programa tinha como objetivo evitar a duplicidade de órgãos responsáveis pelos mesmos assuntos, eliminar a superposição de funções, melhorar os processos internos, desburocratizar, identificar gargalos e deficiências na estrutura dos ministérios, desenvolvendo uma intervenção a fim de melhorar o gerenciamento e a eficiência na administração pública federal. Todavia, a ausência de estrutura de incentivos para a adesão de dirigentes e servidores, e a comunicação com os setores e instituições visados pelo PRQ, levou-o ao fracasso, sendo, então, substituído pelo Programa de Gestão Pública Empreendedora, desenvolvido pela Secretaria de Gestão, do Ministério do Planejamento. O programa se apresentou de forma mais modesta, seletiva e incremental, resultando em um projeto mais bem-sucedido.

O governo FHC obteve alguns êxitos relativos à aprovação da reforma administrativa, especialmente na área de pessoal. Em resumo, houve avanços na revitalização da Escola Nacional de Administração Pública (ENAP), a renovação de quadros da alta administração, a reestruturação de algumas carreiras e a correção significativa de distorções salariais.

Segundo Torres (2004, p. 203), os esforços empreendidos pelo Mare e, posteriormente, pelo Ministério do Planejamento, Orçamento e Gestão pouco conseguiram mudar a mentalidade dos servidores públicos, pelo simples fato de a transformação cultural ser muito lenta e de difícil percepção imediata. A forte presença da cultura patrimonialista na sociedade refletiu com mais intensidade no setor público. Apesar dos avanços, ainda presenciamos práticas patrimonialista envolvidas nos mantos do clientelismo, bloqueando a consolidação da adoção e a divulgação de uma cultura gerencial na administração pública federal, agravando-se ainda mais em âmbito municipal. 
No que se refere aos estados, ocorreram importantes avanços, pois nem sempre as reformas adotadas pelo governo federal eram acompanhadas pelos governos estaduais. Entretanto, as reformas administrativas acabaram sendo impulsionadas pelos seguintes fatores inter-relacionados:

1) a crise financeira dos governos estaduais; 2) a propagação das ideias da Nova Gestão Pública após 1995; 3) a disseminação de boas práticas e inovações administrativas pelo país; 4) o fortalecimento de espaços federativos como o CONSAD (Conselho Nacional de Secretários Estaduais de Administração); 5) a rede criada entre a União e os estados na proposição e negociação do PNAGE (Programa Nacional de Apoio à Modernização da Gestão e do Planejamento dos Estados e do Distrito Federal), um programa de financiamento da modernização das administrações públicas estaduais. (COSTIN, 2010, p. 70).

Para Costin (2010), com a sucessão do governo Lula, a EC 19/1998, ainda que tenha sofrido críticas do Partido dos Trabalhadores, foi preservada no que diz respeito ao componente de orientação para o cidadão, de flexibilização de estruturas, ênfase em desempenho, as novas figuras institucionais (agências reguladoras) e as organizações sociais. No que tange à ideia de mensurar os resultados, dar autonomia gerencial e responsabilização aos gestores, também se manteve a reestruturação de departamentos, a descentralização do orçamento, o treinamento dos funcionários e parcerias com entidades da sociedade civil, consolidando, assim, as mudanças da emenda. Desse modo, a EC 19/1998 desregulamentou algumas práticas burocráticas que não correspondiam mais ao interesse do neoliberalismo, como, por exemplo, a excessiva centralização, e regulamentou práticas gerenciais como a descentralização.

Portanto, o movimento de reforma do aparelho do Estado, segundo Foucault (2001, p. 67) foi elaborado "[...] por pessoas que se pretendem representativas e que têm como ocupação falar pelos outros, em nome dos outros, e é uma reorganização do poder, uma distribuição de poder que se acompanha de uma repressão crescente.”. Pode-se dizer que a EC 19/1998 foi promovida do alto, com pessoas do interesse de um grupo dominante, para atender às demandas do neoliberalismo tencionando reorganizar o poder, por isso, hoje se nota as agências reguladoras capturadas pelo mercado, direcionando diretrizes governamentais para seus interesses. Diferentemente, quando se trata de uma reforma reivindicativa, exigida por aqueles a quem ela diz respeito, deixa de ser uma reforma, passando a ser uma "[...] ação revolucionária que por seu caráter parcial está decidida a colocar em questão a totalidade do poder e de sua hierarquia." (FOUCAULT, 2001, p. 67). 


\subsection{Considerações parciais}

Neste capítulo, discutiu-se a definição dos termos desregulação, regulação, desregulamentação e regulamentação na administração pública federal. Através do desenvolvimento das categorias de administração do Estado, denominados como patrimonialista, burocrática e gerencial. Tem-se no modelo patrimonialista uma administração desregulada, submissa apenas aos interesses privados.

Com a adoção do modelo burocrático, teve início a regulação da administração, visando à separação entre o público e o privado. O modelo gerencial, por sua vez, surgiu para corrigir as disfunções do modelo burocrático e propor a adoção de práticas descentralizadas, flexíveis, de controle e transparência. Para tanto, foi necessário desregulamentar a centralização e rigidez do modelo burocrático, a fim de regulamentar novas ferramentas institucionais de caráter gerencial. Assim, é possível destacar as diversidades da administração pública federal a partir das reformas administrativas.

O movimento por uma administração racional que surgiu através do modelo burocrático weberiano e, depois, pós-burocrático com o modelo gerencial, estava dentro do cenário em que o capitalismo se consolidou como modo de produção dominante a partir do século XIX. A partir daí, tem-se todo o paradigma da modernidade da administração pública associado ao desenvolvimento do capitalismo.

As reformas da administração do Estado ocorreram no momento definido por Santos (2011) como capitalismo organizado e desorganizado. O capitalismo organizado é compreendido entre os finais do século XIX até, aproximadamente, 1965. Esse período fortaleceu os princípios do mercado e do Estado e deu início às reformas burocráticas weberianas. O capitalismo desorganizado começa nos finais dos anos 60 e continua até hoje. É desorganizado porque as formas de organização estão sendo gradualmente desmanteladas. É justamente nesse contexto que se encontram as reformas administrativas de cunho gerencial.

O impulso gerencial da administração pública parte de um modelo ideal desenvolvido nos Estados Unidos e na Inglaterra, países como referência nos avanços do sistema capitalista e que influenciaram os países em desenvolvimento, servindo de fundamento para as reformas administrativas na administração pública federal. Portanto, motivos como a preocupação em reduzir gastos e melhorar a eficiência serviram de justificativas para acompanhar a orientação mundial, para atender ao movimento do capitalismo. Porém, é inegável que as diversidades da administração pública federal, mesmo com cenário desfavorável conduzidos por interesse de um determinado grupo no poder, não impediram os avanços na qualidade e eficiência, 
legitimando conceitos como a transparência, a participação, a prestação de contas e o controle social.

Portanto, para Jean Cruet (1908) a sociedade reforma a lei, mas nunca se viu a lei reformar a sociedade. Assim, nota-se que as leis criadas para superar as práticas patrimonialistas não foram eficazes em razão de o problema estar enraizado na sociedade brasileira, de modo que somente a lei não será suficiente para ocasionar a transformação necessária, sendo essencial uma ação revolucionária na transformação cultural. 


\section{CONSIDERAÇÕES FINAIS}

As diversidades das reformas da administração pública federal que se apresentaram através da desregulamentação e regulamentação são um marco histórico para o enfrentamento da herança da administração patrimonialista. Foi demonstrado, por meio do DL 200/1967 e da EC 19/1998, que as reformas administrativas focaram basicamente em combater práticas como clientelismo, decisões de interesses privados, gastos de pessoal e corrupção. Porém, a letargia nas implantações das reformas e o enraizamento de uma cultura organizacional patrimonialista preservaram as práticas do período colonial. Ao discorrer sobre a administração do Estado, foi possível notar as disfunções persistentes e o distanciamento dos modelos ideais de administrar o Estado com as implantações realizadas no Brasil.

Diante desse cenário, fez-se necessário responder às diversidades das reformas administrativas (DL 200/1967 e EC 19/1998) pela ótica da desregulamentação e regulamentação. Contudo, persiste a interrogação: A reformas administrativas conduziram a administração do Estado brasileiro, para superar as superar as heranças patrimonialistas e as disfunções burocráticas?

Conforme a hipótese descrita, para superar as heranças patrimonialistas e as disfunções burocráticas, foram desenvolvidas medidas que melhoram a forma de administrar o Estado. $\mathrm{O}$ surgimento do modelo gerencial tornou-o, a priori, o modelo ideal para enfrentar esses problemas. Dito isso, sob a ótica da desregulamentação e regulamentação, o modelo gerencial da administração pública federal não logrou êxito no combate às mazelas da administração patrimonialista e burocrática.

Assim, a hipótese deste trabalho se confirmou ao descrevermos, no capítulo três, a análise da interseção entre os modelos, e no capítulo quatro, as diversidades da administração pública brasileira. Constatou-se que houve avanços no combate a algumas práticas da administração patrimonialista, mas não sua extinção. Sendo assim, os excessivos números de cargos, a ausência de planos de carreira, o desinteresse em formar quadros qualificados, ausência de quadros exclusivos de Estado e a ausência de controle apresentaram uma melhora, mas não em sua totalidade como categorizado. Isto se deve ao fato de sua concepção ter uma base ideológica neoliberal e, por isso, não corresponder eficientemente ao desafio em desenvolver a burocracia para melhor servir às pessoas.

O Estado brasileiro, por possuir suas características marcadas pela colonização portuguesa, influenciou diretamente na implantação dos modelos "ideais" de administração. Notou-se que a reforma burocrática começou em 1930, na Era Vargas, avançou em 1967 e 
continuou em 1998, no governo FHC.

A reforma burocrática foi uma consequência clara da emergência de um capitalismo moderno no país, assim como a reforma gerencial teve como objetivo tornar mais eficiente a administração burocrática para atender as concepções do neoliberalismo. Torres (2004) alegou que a reforma gerencial pouco conseguiu mudar a mentalidade dos servidores públicos, pelo simples fato de a transformação cultural ser lenta e de difícil percepção imediata. Porém, como destacou Foucault (2001), o problema não está apenas em mudar a consciência das pessoas, mas, sim, todo o regime político, econômico e institucional no qual o modelo gerencial foi baseado. Por isso, ao pensar a reforma da administração do Estado, é fundamental trabalhar em conjunto, o tipo de Estado, de governo e de administração, bem como a sociedade, para, então, refletir sobre uma ação revolucionária como um todo.

A consequência da doutrinação do capitalismo, que envolve o misticismo do livre mercado, reforçou algumas ideias, como a redução dos gastos nas áreas sociais e a transferência das empresas estatais para o controle do setor privado, formando a base da reforma gerencial promovida por Bresser-Pereira (1998). No entanto, para angariar apoio de opositores políticos para a reforma, foi proposto o modelo social-liberal, ou seja, foram inseridos conceitos socialistas em uma reforma de cunho capitalista, propondo o modelo republicano de Estado.

A proposta social-liberal de Bresser-Pereira (1998), que enfatizou a importância da democracia participativa, torna-se confusa quando deparamo-nos com o contraponto neoliberal, pois, sempre que o interesse do grupo dominante estiver em risco, a democracia é desrespeitada e os direitos sociais são desregulamentados. Assim, o autor (1998) se ausentou da perspectiva do neoliberalismo em lidar com a democracia, pois não seria aceito que a sociedade se desenvolvesse com relação à participação efetiva em debates e decisões sobre seus destinos, pois, nessa situação, os grupos que detêm o poder não enxergam como democracia, mas como crise da democracia.

A crise da democracia se acentuou, como observou Morin (2000), em decorrência do desenvolvimento da enorme máquina em que ciência, técnica e burocracia estão intimamente associadas. Essa relação não apenas produziu conhecimento e elucidação, mas também ignorância e cegueira. Isso ocorreu devido aos inconvenientes da hiper-especialização e da fragmentação do saber. Nesse contexto, tem-se o conhecimento técnico que está reservado aos especialistas e que retira dos cidadãos a possibilidade de pensar ou controlar, alegando não terem ciência sobre o assunto, predominando a decisão pessoal e única do especialista, ausentando-se a consulta de alguma instância democrática.

Não somente a democracia passou a ser questionada, mas o princípio de Estado também 
sofre transformações drásticas. Como descreveu Santos (2011), a ideologia neoliberal, em combinação com as operações transnacionais das grandes empresas e das agências internacionais, conduziu à redução do protagonismo do Estado-nação como ator no sistema mundial. Tal situação foi determinante nas políticas sociais e práticas como desregulamentação, privatização, mercado interno do Estado, com participação nos custos, mercadorização, cidadania ativa tiveram como objetivo reduzir a responsabilidade do Estado na produção de bem-estar social.

O reflexo da degradação do desempenho social do Estado não diminuiu significativamente o peso burocrático, fazendo o crescente enfraquecimento e ineficácia da administração pública se juntar a o crescente autoritarismo de um sem-número de burocracias desajustadas, cada qual exercendo seu microdespotismo sobre os cidadãos cada vez mais impotentes e politicamente incapazes. Nesse contexto, com a falência da miragem dos modelos reformistas de administrar o Estado, pode ser que a busca de modelos de administração pública alternativos, como, por exemplo, o novo serviço público, não seja o caminho, porém, talvez seja o momento de criar possibilidades à administração pública, o que implica, também, adotar alternativas de Estado.

Foi possível evidenciar que as dificuldades de implantar o modelo burocrático ocorreram devido à raiz cultural ligada ao patrimonialismo, assim como o modelo gerencial travou porque sua base dependia do estágio racional do modelo burocrático weberiano. Por essa razão, a EC 19/1998 é a consequência da modernização capitalista e, até os dias atuais, não houve mais uma reforma de grandes proporções para a administração pública brasileira.

É importante destacar que a EC 19/1998 foi estabelecida em um cenário em que os atos institucionais redefiniram as relações e funções dos vários órgãos e entidades do Estado, a fim de executarem as tarefas essenciais à implantação do plano neoliberal conduzido por uma elite capitalista que detém o poder político e econômico. Sendo assim, a competência da burocracia brasileira continuou a satisfazer apenas o interesse de uma minoria que dela se apropriou para legitimar seus próprios interesses, e não o interesse coletivo, pois tinha a ciência de sua importância para o grupo dominante.

Ficou demonstrado que o movimento por uma administração pública gerencial, definido no Plano Diretor da Reforma do Aparelho do Estado de 1995, que versou sobre a necessidade de desregulamentar e desburocratizar, conforme as palavras de Bresser-Pereira (1998), tinha como forma de governo a democracia participativa inserida no Estado republicano, porém, todo seu desenvolvimento foi capturado para atender à concepção de um Estado neoliberal, através da doutrinação, defendendo a necessidade de redução de gastos, privatização e contenção da 
crise fiscal, instaurando uma reforma apenas para coroar o projeto neoliberal de modernização do Estado capitalista brasileiro.

O foco do gerencialismo não foi uma ruptura engessada e ausente de participação social, mas, sim, uma reorganização do Estado neoliberal de administrar, voltando suas ações para os interesses do mercado, ausentando-se o que Costin (2010) asseverou ser o papel do Estado moderno, como ator redutor de diferenças sociais, praticando a justiça distributiva. Também não logrou êxito, como propôs Nerling (1997), em domesticar o monstro da burocracia para melhor servir às pessoas em sua totalidade.

É inegável que o modelo gerencial trouxe avanços para a administração pública federal, introduziu conceitos importantes como a transparência, a participação, a prestação de contas, a eficiência e o controle social. Porém a modernização e a racionalização ocorrem conforme o "espirito" de seu tempo, respondendo a evolução da administração pública federal às necessidades e às complexidades das organizações ao se adaptarem aos cenários de mudanças e transformações.

Sendo assim, faz-se necessário buscar uma administração racional, mas uma racionalidade no sentido atribuído por Morin (2009), como fruto do debate argumentado das ideias, e não como a propriedade de um sistema de ideias, pois o racionalismo que ignora os seres, a subjetividade, a afetividade e a vida é irracional.

Nessas circunstâncias, é essencial incluir a solidariedade como um dos princípios fundamentais da administração pública; retomar o fortalecimento distributivo das políticas sociais com a noção de solidariedade, caracterizando a obrigação política de forma horizontal, de cidadão para cidadão. É fundamental pensar a reforma da administração pública federal horizontalmente, ou seja, pela base, fortalecida pelos princípios de solidariedade, participação e controle. Somente desse modo, será possível deixar de impor soluções pelo alto, de forma vertical (contribuintes e Estado, e entre os beneficiários das políticas sociais e o Estado).

É necessário, ainda, evitar a despolitização da política, contextualizada por Morin (2009), que se autodissolve na administração, na especialização, na economia, no pensamento quantificante (sondagens, estatísticas), pois, assim, a fragmentação perde a compreensão da vida, dos sofrimentos, dos desamparos, das solidões, das necessidades não quantificáveis, contribuindo para a regressão democrática, isolando os cidadãos das tomadas de decisões mais importantes para os problemas da administração pública federal.

Tendo como base os conceitos de Santos (2011), atualmente, a administração do Estado pode ser considerada como a administração-regulação, isto é, seu ponto de ignorância é o caos e seu ponto de saber é a ordem. A partir desse raciocínio, a administração patrimonialista é o 
caos e a administração burocrática/gerencial é a ordem (regulação). No entanto, essa divisão não foi suficiente para responder às necessidades dos cidadãos e será preciso pensar a administração pública como emancipatória.

A administração-emancipação, baseado na concepção de Santos (2011), tem seu ponto de ignorância no colonialismo e seu ponto de saber na solidariedade. É, pois, imprescindível intensificar a trajetória da condição ou momento da ignorância (o colonialismo) para a condição ou momento do saber (solidariedade), tornando a solidariedade uma prática política.

Portanto, é fundamental a substituição, no espaço de produção, do capitalismo; no espaço do mercado, substituir o consumismo pelas necessidades fundamentais; no espaço da cidadania, a permutação da democracia fraca pela democracia forte e, por fim, no espaço da administração, a alteração da administração-regulação para a administração-emancipação. 


\section{REFERÊNCIAS}

BELTRÃO, H. Descentralização e liberdade. 3. ed. Brasília: Universidade de Brasília, 2002. BOBBIO, N. O conceito de sociedade civil. Rio de Janeiro: Edições Graal, 1982.

La teoria delle forme di governo. Turim: G. Giappichelli, 1976.

Estado, governo e sociedade. Para uma teoria geral da política. 14. ed. São Paulo: Paz e Terra, 2007.

BRASIL. Constituição (1988). Constituição da República Federativa do Brasil. Brasília, DF: Supremo Tribunal Federal, 2017.

Decreto, de 07 de março de 2017. Cria o Conselho Nacional para a Desburocratização -Brasil Eficiente e dá outras providências. Título do suporte em que foi publicado. Brasília, 2017.

Decreto $n^{\circ} 5.378$, de 23 de fevereiro de 2005. Institui o Programa Nacional de Gestão Pública e Desburocratização -GESPÚBLICA e o Comitê Gestor do Programa Nacional de Gestão Pública e Desburocratização e dá outras providências. Título do suporte em que foi publicado. Brasília, 2005.

Emenda Constitucional no 19, de 04 de junho de 1998. Modifica o regime e dispõe sobre princípios e normas da Administração Pública, servidores e agentes políticos, controle de despesas e finanças públicas e custeio de atividades a cargo do Distrito Federal, e dá outras providências. Título do suporte em que foi publicado. Brasília, 1998. Brasília: 1995.

Presidência da República. Plano Diretor da Reforma do Aparelho do Estado.

Decreto $n^{\circ}$ 99.179, de 15 de março de 1990. Institui o Programa Federal de Desregulamentação. Título do suporte em que foi publicado. Brasília, 1990.

Decreto $n^{\circ} 83.740$, de 18 de julho de 1979. Institui o Programa Nacional de Desburocratização e dá outras providências. Título do suporte em que foi publicado.Brasília, 1979.

Decreto-lei nº 200, de 25 de fevereiro de 1967. Dispõe sôbre a organização da Administração Federal, estabelece diretrizes para a Reforma Administrativa e dá outras providências. Título do suporte em que foi publicado. Brasília, 1967.

BRESSER-PEREIRA, L. C. Construindo o Estado republicano: democracia e reforma da gestão pública. Rio de Janeiro: FGV, 2009. 1998.

Sociedade civil: sua democratização para a reforma do Estado. Brasília: ENAP,

Da administração pública burocrática à gerencial. Revista do Serviço Público, n. 1, Brasília, ENAP, jan./abr. 1996. 
BRESSER-PEREIRA, L. C.; SPINK, P. Reforma do Estado e administração pública gerencial. 7. ed. Rio de Janeiro: FGV, 2006.

CHIAVENATO, I. Administração geral e pública. 4. ed. São Paulo: Elsevier, 2009.

COSTIN, C. Administração pública. 1. ed. Rio de Janeiro: Elsevier, 2010.

CRUET, J. A vida do direito e a inutilidade das leis. Lisboa: Editora 73, 1908.

DALLARI, D. de A. Elementos de teoria geral do Estado. São Paulo: Saraiva, 1995.

DIAS, J. de N. T. A reforma administrativa de 1967. 2. ed. Rio de Janeiro: Fundação Getúlio Vargas, 1969.

FAORO, R. Os donos do poder: formação do patronato político brasileiro. Porto Alegre: Globo, 1984.

FOUCAULT, M. Microfísica do poder. 16. ed. Rio de Janeiro: Graal, 2001.

GRAHAM, L. S. Civil service reform in Brazil: principles versus practice. Texas:

University of Texas Press, 1968.

GUEVARA, E. de la S. Contra el burocratismo. Biblioteca de Textos Marxistas, 1963.

Disponível em: <https://www.marxists.org/espanol/guevara/03_63.htm〉. Acesso em: 05 fev. 2016.

INSTITUTO DE PESQUISA ECONÔMICA APLICADA (IPEA). Subsídios para Reforma do Estado: desregulamentação e novas regulações. 1993. v. 3

MAQUIAVEL. N. O Príncipe. 5. ed. São Paulo: Nova Cultural, 1991.

MORIN, E. Os sete saberes necessários à educação do futuro. 2. ed. Brasília: UNESCO, 2000 .

NERLING. M. A. A burocracia cede espaço: A experiência do orçamento participativo. 1997. 237 f. Dissertação (Mestrado em Direito) - Universidade Federal de Santa Catarina, Santa Catarina, 1997.

NOVAES, H. T.; DAL RI, N. M. Movimentos sociais contemporâneos. Uberlândia: Navegando Publicações, 2017. v. 2.

PAIVA, C. H. A. A burocracia no Brasil: as bases da administração pública nacional em perspectiva histórica (1920-1945). História, Franca, v. 28, n. 2, p. 775-796, 2009. Disponível em: <http://www.scielo.br/scielo.php?script=sci_arttext\&pid=S010190742009000200027\&lng=en\&nrm=iso>. Acesso em: 10 jul. 2016.

PETERS, B. G.; PIERRE, J. Administração pública: coletânea. Brasília: Enap, São Paulo: Editora UNESP, 2010. 
PIMENTA, C. C. Aspectos recentes da organização e das políticas de modernização da função pública federal. Revista de Administração Pública, Rio de Janeiro, v. 28, n. 2, abr. 1994.

POLLIT, C. The Citizen's Charter: a preliminary analysis. Public Money and Management, v. 14, n. 2, 1994.

Managerialism and the public services: the Anglo-American experience. Oxford Mass., Basil Blackwell, 1990.

SANTOS, B. de S. A crítica da razão indolente: contra o desperdício da experiência. 8. ed. São Paulo: Cortez, 2011.

Um discurso sobre as ciências. 7. ed. São Paulo: Cortez, 2010.

TORRES, M. D. de F. Estado, democracia e administração pública no Brasil. Rio de Janeiro: FGV, 2004.

TURA, M. A. R. História institucional do Brasil real. Curitiba: Juruá, 2001.

URICOECHEA, F. O minotauro imperial: a burocratização do estado patrimonial brasileiro no século XIX. Rio de Janeiro/São Paulo: DIFEL, 1978. (Coleção Corpo e Alma do Brasil).

WEBER, M. Economia e Sociedade. Fundamentos da sociologia compreensiva. 4. ed. Brasília: Editora Universidade de Brasília, 2014. v 1.

Economia e sociedade: fundamentos da sociologia compreensiva. 4. ed. Brasília: Editora Universidade de Brasília, 2014. v. 2. 